\title{
Doping of Graphitic Carbon Nitride with Non-Metal Elements and Its Applications in Photocatalysis
}

\author{
Halyna Starukh ${ }^{1,2,3}$ and Petr Praus $1,2, *$ (D) \\ 1 Institute of Environmental Technology, VŠB-Technical University of Ostrava, 17. listopadu 15, \\ 70800 Ostrava-Poruba, Czech Republic; halyna.starukh@vsb.cz \\ 2 Department of Chemistry, VŠB-Technical University of Ostrava, 17. listopadu 15, 70800 Ostrava-Poruba, \\ Czech Republic \\ 3 Chuiko Institute of Surface Chemistry of National Academy of Sciences of Ukraine, 17 General \\ Naumov Street, 03164 Kyiv, Ukraine \\ * Correspondence: petr.praus@vsb.cz; Tel.: +420-59-699-1675
}

Received: 31 August 2020; Accepted: 23 September 2020; Published: 28 September 2020

check for updates

\begin{abstract}
This review outlines the latest research into the design of graphitic carbon nitride $\left(\mathrm{g}-\mathrm{C}_{3} \mathrm{~N}_{4}\right)$ with non-metal elements. The emphasis is put on modulation of composition and morphology of $\mathrm{g}-\mathrm{C}_{3} \mathrm{~N}_{4}$ doped with oxygen, sulfur, phosphor, nitrogen, carbon as well as nitrogen and carbon vacancies. Typically, the various methods of non-metal elements introducing in $g-C_{3} N_{4}$ have been explored to simultaneously tune the textural and electronic properties of $g-C_{3} N_{4}$ for improving its response to the entire visible light range, facilitating a charge separation, and prolonging a charge carrier lifetime. The application fields of such doped graphitic carbon nitride are summarized into three categories: $\mathrm{CO}_{2}$ reduction, $\mathrm{H}_{2}$-evolution, and organic contaminants degradation. This review shows some main directions and affords to design the $\mathrm{g}-\mathrm{C}_{3} \mathrm{~N}_{4}$ doping with non-metal elements for real photocatalytic applications.
\end{abstract}

Keywords: graphitic carbon nitride; doping; non-metals; photocatalysis

\section{Introduction}

Graphitic carbon nitride has been of interest since Wang et al. published their paper about its ability of photocatalytic water splitting in 2009 [1]. It is a two-dimensional (2D) metal-free semiconducting material with the ability to absorb visible light due to the band gap energy of $2.7 \mathrm{eV}$. Other interesting properties, such as high thermal, physical, chemical, and photochemical stability, predetermines it for solar cell fabrications, imaging, sensing of some compounds, and also for photocatalysis [2-10]. On the other hand, there are some problems connected to fast recombination of photoinduced electrons and holes and low specific surface area, which must be solved.

Introducing non-metal elements into the $\mathrm{g}-\mathrm{C}_{3} \mathrm{~N}_{4}$ framework modulates its surface morphology, size of particles, electronic and optical properties, and other physico-chemical properties. Since bare $\mathrm{g}-\mathrm{C}_{3} \mathrm{~N}_{4}$ absorbs light up to $420 \mathrm{~nm}$, the non-metal incorporation allows us to extend absorption of visible irradiation and to reduce recombination of photoinduced electrons and holes. Over the past few years, a lot of articles on non-metal doping have been published. This literature review is focused on recent progress in the synthesis and design of non-metal doped $g-\mathrm{C}_{3} \mathrm{~N}_{4}$ for applications in photocatalysis.

\section{Oxygen-Doped g- $\mathrm{C}_{3} \mathrm{~N}_{4}$}

The most common ways to introduce elemental oxygen into g- $\mathrm{C}_{3} \mathrm{~N}_{4}$ (Table 1) are oxidation methods, such as oxidation of $\mathrm{g}-\mathrm{C}_{3} \mathrm{~N}_{4}$ with acids [11-13], thermal oxidation [14-23], oxidation with 
hydrogen peroxide $\mathrm{H}_{2} \mathrm{O}_{2}$ [24-29], hydrothermal treatment [30-32], pretreatment of synthetic precursors followed by thermal oxidation [33-37], and solvothermal methods [38-40].

Putri et al. performed the doping with oxygen atoms via hydrothermal treatment of bulk g- $\mathrm{C}_{3} \mathrm{~N}_{4}$ with $\mathrm{H}_{2} \mathrm{O}_{2}$ at $120{ }^{\circ} \mathrm{C}$ [24]. The concentration of $\mathrm{H}_{2} \mathrm{O}_{2}$ influenced the specific surface area (SSA) of $\mathrm{O}-\mathrm{g}-\mathrm{C}_{3} \mathrm{~N}_{4}$. The highest SSA of O-g- $\mathrm{C}_{3} \mathrm{~N}_{4}$ was determined to be $85 \mathrm{~m}^{2} \cdot \mathrm{g}^{-1}$ compared to $75 \mathrm{~m}^{2} \cdot \mathrm{g}^{-1}$ for pristine $g-C_{3} \mathrm{~N}_{4}$. The photocatalytic experiment did not reveal the influence of SSA on activity of O-g- $\mathrm{C}_{3} \mathrm{~N}_{4}$ photocatalysts. Fourier-transformed infrared spectroscopy (FTIR) allowed authors to get confirmation that the oxygen functionalization of $\mathrm{g}-\mathrm{C}_{3} \mathrm{~N}_{4}$ was achieved by its oxidation with $\mathrm{H}_{2} \mathrm{O}_{2}$. The new band at $1070 \mathrm{~cm}^{-1}$ was described as vibration of new stretching modes of N-O groups. The insertion of elemental oxygen into g- $\mathrm{C}_{3} \mathrm{~N}_{4}$ was confirmed by $\mathrm{X}$-ray photoelectron spectroscopy (XPS). The apparent new peak at the binding energy cca $530 \mathrm{eV}$ was ascribed to oxygen doping into the $\mathrm{g}_{-} \mathrm{C}_{3} \mathrm{~N}_{4}$ lattice. The peaks of adhering oxygen atoms directly bound to carbon atoms $(\mathrm{C}-\mathrm{O})$ and substitutional $\mathrm{O}$ in the form of $\mathrm{N}-\mathrm{C}-\mathrm{O}$ heterocyclic rings of the graphitic structure were observed on a wide scan survey. It was also confirmed that oxygen doping greatly influenced the carbon chemical state. An optical properties study demonstrated that oxygen doping caused band gap narrowing due to the formation of sub-gap impurity states that extend the light absorption of $\mathrm{O}-\mathrm{g}-\mathrm{C}_{3} \mathrm{~N}_{4}$ (Figure 1).
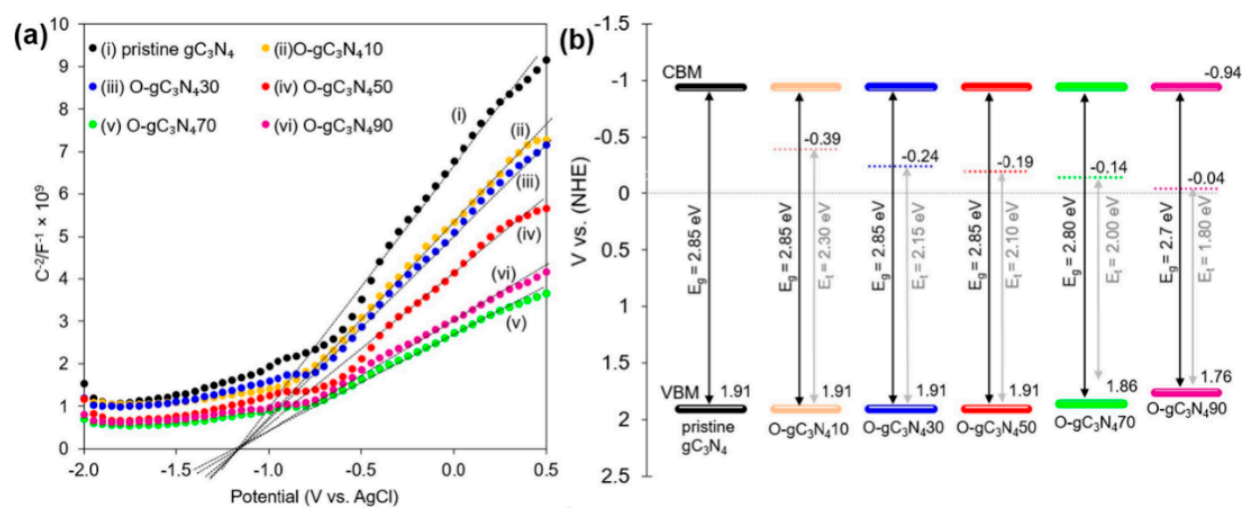

Figure 1. Mott-Schottky plots for as-synthesized $\mathrm{g}-\mathrm{C}_{3} \mathrm{~N}_{4}$ and $\mathrm{O}-\mathrm{g}-\mathrm{C}_{3} \mathrm{~N}_{4}$ samples (a) and postulated band structure of pristine $\mathrm{g}-\mathrm{C}_{3} \mathrm{~N}_{4}$ and increasing oxidation of $\mathrm{g}-\mathrm{C}_{3} \mathrm{~N}_{4}$ (b) Reprinted from [24], Copyright (2020), with permission from Elsevier.

The oxygen groups in the $\mathrm{g}-\mathrm{C}_{3} \mathrm{~N}_{4}$ lattice were supposed to form midgap states, that is, localized states in the band gap. It was observed the decreasing of the midgap energy in the values from 2.30 to $1.80 \mathrm{eV}$ when 10 and $90 \mathrm{~cm}^{3}$ of $\mathrm{H}_{2} \mathrm{O}_{2}$ were used. At the same time, for the majority of $\mathrm{O}-\mathrm{g}-\mathrm{C}_{3} \mathrm{~N}_{4}$ samples, the intrinsic band gap value was $2.85 \mathrm{eV}$. The band structure transformation with increasing oxygen doping level in $\mathrm{g}-\mathrm{C}_{3} \mathrm{~N}_{4}$ were suggested to occur according to the scheme presented in Figure 2.

Similar characteristics of O-g- $\mathrm{C}_{3} \mathrm{~N}_{4}$ were reported by Zhang et al. [41], which performed the oxygen doping in the same way. The reducing of photogenerated carrier recombination was confirmed with photoluminescence (PL) method. The study of optical properties of O-g- $\mathrm{C}_{3} \mathrm{~N}_{4}$ show that the $\mathrm{H}_{2} \mathrm{O}_{2}$ treatment had no effect on the band gap of the catalyst. It caused a significant effect on enlarging a photocatalytic response range of the obtained material and increased its absorption intensity.

Huang et al. performed the oxidative treatment of bulk g- $\mathrm{C}_{3} \mathrm{~N}_{4}$ with peroxymonosulfate (PMS) at $60{ }^{\circ} \mathrm{C}$ [18]. As the SSA of g- $\mathrm{C}_{3} \mathrm{~N}_{4}$ after the oxidation was approximately unchanged, it was suggested that PMS interacts with the surface groups of $\mathrm{g}-\mathrm{C}_{3} \mathrm{~N}_{4}$ without its exfoliation into a single or few layers. The atomic percentage of oxygen increased on $\mathrm{O}-\mathrm{g}-\mathrm{C}_{3} \mathrm{~N}_{4}$ surface to $6.9 \%$ in comparison with $1.8 \%$ in g- $\mathrm{C}_{3} \mathrm{~N}_{4}$ as confirmed by XPS. The detailed study of the chemical state of $\mathrm{C}, \mathrm{N}$, and $\mathrm{O}$ atoms in O-g- $\mathrm{C}_{3} \mathrm{~N}_{4}$ allowed authors to report that the doped oxygen atoms mainly exist as carbonyl and carboxyl groups. The doping of more oxygen groups in $\mathrm{O}-\mathrm{g}-\mathrm{C}_{3} \mathrm{~N}_{4}$ caused a decrease of the optical band gap from 2.82 to 
$2.79 \mathrm{eV}$. The doping of oxygen improved the separation of photo-generated carriers that was concluded from the decreasing PL intensity after oxidation of g- $\mathrm{C}_{3} \mathrm{~N}_{4}$ with PMS.
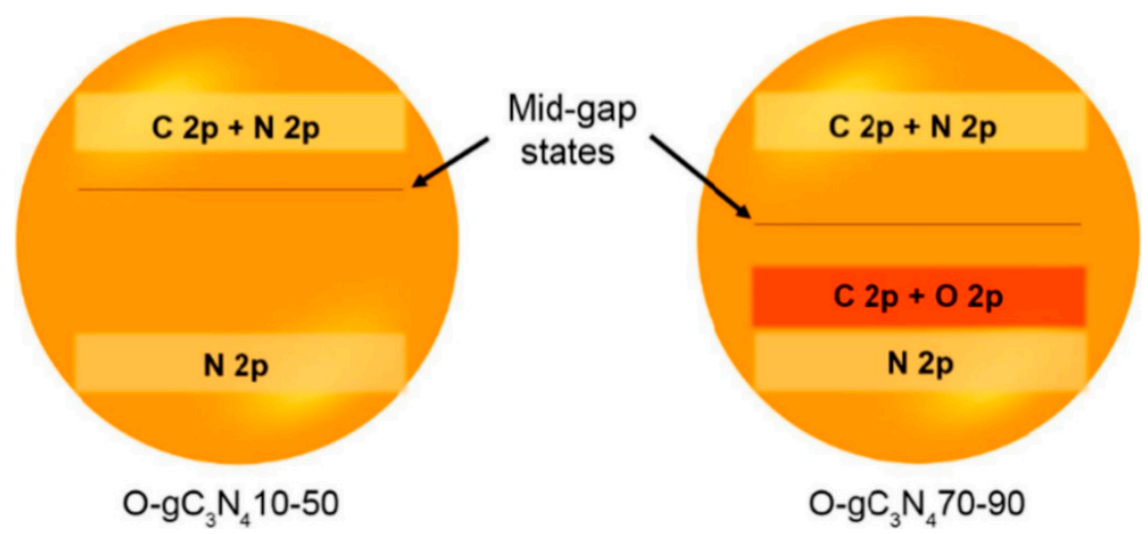

Figure 2. Band structure transformation with increasing oxygen doping level in $\mathrm{g}_{-} \mathrm{C}_{3} \mathrm{~N}_{4}$. Reprinted from [24], Copyright (2020), with permission from Elsevier.

$\mathrm{Li}$ et al. performed the synthesis of nanostructured $\mathrm{O}-\mathrm{g}-\mathrm{C}_{3} \mathrm{~N}_{4}$ with $\mathrm{C}-\mathrm{O}-\mathrm{C}$ and $\mathrm{C}=\mathrm{O}$ groups by a two-step thermal treatment process [19]. Increase of the O content was observed for every step of the treatment as was determined by elemental analysis (EA). The $O$ content in pristine $g-C_{3} N_{4}$ and its products of the first and second steps of the treatment were $4.07 \%, 5.01 \%$, and $8.43 \%$, respectively. The decreasing of $\mathrm{N}$ content from $60.30 \%$ to $54.18 \%$ can be explained by substituting $\mathrm{N}$ atoms with $\mathrm{O}$ ones in the carbon nitride skeleton. The study of elemental valence state in the samples by XPS revealed that $\mathrm{C}-\mathrm{O}-\mathrm{C}$ groups were introduced into the precursor with copolymerization of urea and ammonium acetate at the first step of synthesis, and the $\mathrm{C}=\mathrm{O}$ groups were introduced into $\mathrm{O}-\mathrm{g}-\mathrm{C}_{3} \mathrm{~N}_{4}$ at the second thermal treatment step. The electron paramagnetic resonance (EPR) signal intensity study of O-g- $\mathrm{C}_{3} \mathrm{~N}_{4}$ revealed internal electric field between $\mathrm{O}$ and tri-s-triazines that caused the remarkable enhancement of visible-light photocatalytic pollutant degradation. The presence of two types of oxygen functional groups caused the polarization of charge distribution, which formed an internal electric field. The negative pole played the oxygen-containing zone and the positive pole played the tri-s-triazine part.

The strategy of another group of researchers concerned the development of purposefully designing precursor for the further thermal treatment [42]. A new hydroxylated and carbonylated melamine for synthesis of porous O-g- $\mathrm{C}_{3} \mathrm{~N}_{4}$ nanosheets (OCNNS) was obtained by a hydrothermally ethanol-assisted reforming of melamine at $200^{\circ} \mathrm{C}$. During the polymerization of the precursor, oxygen atoms of anchored hydroxyl groups contributed to oxygen doping, while alternative oxygen atoms in anchored carbonyl groups were simultaneously removed in the form of water forming porous nanostructures. The porous OCNNS demonstrated the increased specific surface area $\left(67.4 \mathrm{~m}^{2} \cdot \mathrm{g}^{-1}\right)$ providing more active sites, and enhanced the transfer and separation of charges. The $\mathrm{C}-\mathrm{O}$ bond formation in O-g- $\mathrm{C}_{3} \mathrm{~N}_{4}$ was demonstrated with XPS. C-O peaks exhibited a progressively increased intensity with increasing amount of ethanol used for the precursor synthesis. The band gaps of O-g- $\mathrm{C}_{3} \mathrm{~N}_{4}$ and $g-\mathrm{C}_{3} \mathrm{~N}_{4}$ were determined to be $2.67 \mathrm{eV}$ and $2.60 \mathrm{eV}$, respectively. It was established that $\mathrm{O}-\mathrm{g}-\mathrm{C}_{3} \mathrm{~N}_{4}$ satisfied with the thermodynamic condition for photocatalytic $\mathrm{H}_{2}$ production, and its conduction band energy was upshifted, confirming the increasing of photoreduction capability.

The solvothermal method was applied by Wei et al. to fabricate a series of O-doped g- $\mathrm{C}_{3} \mathrm{~N}_{4}$ photocatalyst [22]. The copolymerization of 1,3,5-trichlorotriazine and various amounts of dicyandiamide was performed at a relatively low temperature. The absorption band of ultraviolet- visible (UV-Vis) diffuse reflectance (DR) spectra of O-g- $\mathrm{C}_{3} \mathrm{~N}_{4}$ was red-shifted, which evidenced that introducing oxygen extended the sensitivity of obtained materials to a wider range of light. Compared to pristine $g-C_{3} \mathrm{~N}_{4}$ with a band gap of $2.73 \mathrm{eV}, \mathrm{O}-\mathrm{g}-\mathrm{C}_{3} \mathrm{~N}_{4}$ demonstrated narrowing of the band gap from 2.54 to $2.09 \mathrm{eV}$. 
Table 1. Synthetic methods, applications, and photocatalytic efficiency of O-doped $\mathrm{g}_{-} \mathrm{C}_{3} \mathrm{~N}_{4}$.

\begin{tabular}{|c|c|c|c|c|c|c|}
\hline Precursor & Synthetic Method & $\begin{array}{c}\text { C/O Ratio, } \\
\text { Doped (Pristine) }\end{array}$ & Photocatalytic Process & $\begin{array}{c}\text { Conditions of the } \\
\text { Process }\end{array}$ & $\begin{array}{c}\text { Efficiency } \\
\text { Doped/Pristine }\end{array}$ & References \\
\hline Urea & $\begin{array}{l}\mathrm{H}_{2} \mathrm{O}_{2} \text { hydrothermal } \\
\text { treatment, } 120^{\circ} \mathrm{C}\end{array}$ & $\begin{array}{c}\text { Surface } \mathrm{O} \text { at. } \% \text { in } \\
\text { O-doped } \mathrm{g}-\mathrm{C}_{3} \mathrm{~N}_{4} \\
3.23-6.59 \text { by XPS } \\
3.16 \% / 2.73 \%\end{array}$ & $\mathrm{H}_{2}$ evolution & $\begin{array}{l}500 \mathrm{~W} \text { Xe lamp, simulate } \\
\text { solar irradiation; } 30 \mathrm{vol} \% \\
\text { triethanolamine (TEOA) }\end{array}$ & $\begin{array}{l}408.4 \mu \mathrm{mol} \cdot \mathrm{g}^{-1} / \\
317.9 \mu \mathrm{mol} \cdot \mathrm{g}^{-1}\end{array}$ & [24] \\
\hline Melamine & $\begin{array}{l}\text { PMS hydrothermal } \\
\text { treatment, } 60^{\circ} \mathrm{C}\end{array}$ & $\begin{array}{c}\text { by Energy-Dispersive } \\
\text { X-Ray Spectroscopy } \\
\text { (EDS) } \\
1.8 \% / 2.8 \% \text { by XPS }\end{array}$ & $\begin{array}{c}\text { Rhodamine } \mathrm{B}(\mathrm{RhB}) \\
\text { destruction }\end{array}$ & $\begin{array}{l}500 \mathrm{~W} \text { halogen lamp, } \\
\text { filter } \lambda>420 \mathrm{~nm}\end{array}$ & $0.079 \mathrm{~min}^{-1} / 0.0032 \mathrm{~min}^{-1}$ & [17] \\
\hline Urea & $\begin{array}{l}\mathrm{H}_{2} \mathrm{O}_{2} \text { hydrothermal } \\
\text { treatment, } 120^{\circ} \mathrm{C}\end{array}$ & - & $\begin{array}{l}\text { RhB, Methyl orange } \\
\text { (MO) destruction }\end{array}$ & $\begin{array}{l}500 \text { W Xe lamp, simulated } \\
\text { solar irradiation }\end{array}$ & $\begin{array}{l}\text { RhB: } 0.1074 \mathrm{~h}^{-1} / 0.0170 \mathrm{~h}^{-1} \\
\text { MO: } 0.2287 \mathrm{~h}^{-1} / 0.0095 \mathrm{~h}^{-1}\end{array}$ & [41] \\
\hline $\begin{array}{l}\text { Urea, ammonium } \\
\text { acetate }\end{array}$ & $\begin{array}{l}\text { two-step thermal } \\
\text { treatment }\end{array}$ & $\begin{array}{l}4.3 / 8.8 \text { by elemental } \\
\text { analysis (EA) }\end{array}$ & $\begin{array}{l}\text { bisphenol A (BPA), } \\
\text { phenol (Ph), } \\
\text { 2-chlorphenol (2-Ph), } \\
\text { diphenhydramine } \\
\text { destruction (DP) }\end{array}$ & $\begin{array}{l}\text { Light-emitting diode } \\
\text { (LED) lamp, } \\
\lambda=420-780 \mathrm{~nm}\end{array}$ & $\begin{array}{c}\text { Total organic carbon (TOC) } \\
\text { removal rate: } \\
\text { BPA } 72.79 \% / 9.27 \% \\
\text { Ph } 67.3 \%, 2-\mathrm{Ph} 61.5 \% \text {, DP } \\
55.0 \%\end{array}$ & [19] \\
\hline Melamine, ethanol & $\begin{array}{c}\text { Thermal } \\
\text { polymerization }\end{array}$ & $\begin{array}{c}\text { Atom. \% (O) } \\
\text { 3.25/- by XPS }\end{array}$ & $\mathrm{H}_{2}$ evolution & $\begin{array}{c}350 \mathrm{~W} \text { Xe lamp, } \\
\text { filter } \lambda>420 \mathrm{~nm}, \\
10 \% \text { vol } \% \text { TEOA, } \\
\text { Pt co-catalyst }(1 \mathrm{wt} . \%)\end{array}$ & $\begin{array}{l}64.30 \mu \mathrm{mol} \cdot \mathrm{h}^{-1} / \\
3.6 \mu \mathrm{mol} \cdot \mathrm{h}^{-1}\end{array}$ & [42] \\
\hline $\begin{array}{l}\text { 1,3,5-Trichloro-triazine, } \\
\text { dicyandiami-de }\end{array}$ & $\begin{array}{l}\text { Solvothermal } \\
\text { method, } 200^{\circ} \mathrm{C}\end{array}$ & $\begin{array}{l}\mathrm{C}: \mathrm{N}: \mathrm{O} \\
1.08: 1: 0.23 / \\
0.69: 1: 0.03 \\
\text { by XPS }\end{array}$ & $\begin{array}{l}\mathrm{H}_{2} \text { evolution; } \\
\text { RhB destruction }\end{array}$ & $\begin{array}{c}\text { Visible light, } \lambda>420, \\
\text { Pt co-catalyst }(0.3 \text { wt. } \%)\end{array}$ & $\begin{array}{c}\mathrm{H}_{2} \text { evolution: } \\
3174 \mu \mathrm{mol} \cdot \mathrm{h}^{-1} \mathrm{~g}^{-1} / 846 \\
\mu \mathrm{mol} \cdot \mathrm{h}^{-1} \cdot \mathrm{g}^{-1} \\
\mathrm{RhB} \text { degradation: } \\
0.249 \mathrm{~min}^{-1} / 0.007 \mathrm{~min}^{-1}\end{array}$ & [22] \\
\hline Melamine & $\begin{array}{c}\text { Thermal } \\
\text { polycondensation }\end{array}$ & 12.5/trace by XPS & $\mathrm{CO}_{2}$ reduction & $\begin{array}{l}350 \mathrm{~W} \text { Xe lamp, } \\
\text { filter } \lambda>420 \mathrm{~nm}\end{array}$ & $\begin{array}{c}\mathrm{CH}_{3} \mathrm{OH} \text { production } \\
0.88 \mu \mathrm{mol} \cdot \mathrm{g}^{-1} \cdot \mathrm{h}^{-1} / \\
0.17 \mu \mathrm{mol} \cdot \mathrm{g}^{-1} \cdot \mathrm{h}^{-1}\end{array}$ & [43] \\
\hline Dicyandia-midine & $\begin{array}{l}\text { Hydrothermal } \\
\text { followed by } \\
\text { calcination }\end{array}$ & $\begin{array}{l}\text { O content (wt. } \%) \\
5.23 / 0.17 \text { by EA }\end{array}$ & $\mathrm{N}_{2}$ fixation & $\begin{array}{c}500 \mathrm{~W} \text { Xenon lamp filter } \\
\lambda>420 \mathrm{~nm}, \\
10 \text { vol. } \% \text { methanol as } \\
\text { sacrificial agents }\end{array}$ & $\begin{array}{l}118.8 \mathrm{mg} \cdot \mathrm{l}^{-1} \cdot \mathrm{h}^{-1} \cdot \text { gcat }^{-1} / \\
5.86 \mathrm{mg} \cdot \mathrm{l}^{-1} \cdot \mathrm{h}^{-1} \cdot \text { gcat }^{-1}\end{array}$ & [18] \\
\hline
\end{tabular}




\section{Nitrogen-Doped g- $\mathrm{C}_{3} \mathrm{~N}_{4}$}

The number of publications on obtaining nitrogen-doped graphitic carbon nitride $\left(\mathrm{N}-\mathrm{g}-\mathrm{C}_{3} \mathrm{~N}_{4}\right)$ is much lower in comparison with the number of publications on carbon, oxygen, phosphorus, and sulfur doped g- $\mathrm{C}_{3} \mathrm{~N}_{4}$. The reason for the limited production of $\mathrm{N}-\mathrm{g}-\mathrm{C}_{3} \mathrm{~N}_{4}$ is the application of non-environmentally friendly precursors, such as hydroxylammonium chloride and hydrazine hydrate. Some processes of the $\mathrm{N}-\mathrm{g}-\mathrm{C}_{3} \mathrm{~N}_{4}$ synthesis generally contain complicated and long-lasting steps. The presented reports on the synthesis and characterization of $\mathrm{N}-\mathrm{g}-\mathrm{C}_{3} \mathrm{~N}_{4}$ and its application in photocatalysis inspired researchers to develop appropriate methods of introducing nitrogen into the g- $\mathrm{C}_{3} \mathrm{~N}_{4}$ lattice (Table 2). Different reaction paths were applied to increase the $\mathrm{N}$ content in $\mathrm{g}-\mathrm{C}_{3} \mathrm{~N}_{4}$ by introducing nitrogen atoms into g- $\mathrm{C}_{3} \mathrm{~N}_{4}$ matrices [44-55] and by the modification of $g-\mathrm{C}_{3} \mathrm{~N}_{4}$ surface [56-61].

An extremely rapid method of the high-nitrogen content carbon nitride production was offered by Miller et al. [44-46]. They decomposed a single molecular precursor, trichloromelamine, which briefly generated internal temperatures near $400{ }^{\circ} \mathrm{C}$ and resulted in amorphous $\mathrm{C}_{3} \mathrm{~N}_{4+\mathrm{x}}$, where $0.5<\mathrm{x}<0.8$. According to the report the carbon centers of the obtained materials primarily had $\mathrm{sp}^{2}$ hybridization, the layered structure consisted of triazine $\left(\mathrm{C}_{3} \mathrm{~N}_{3}\right)$ rings, and nitrogen species bound the triazines. The N-g- $\mathrm{C}_{3} \mathrm{~N}_{4}$ was thermally stable up to $600{ }^{\circ} \mathrm{C}$, possessed a moderately porous structure with nanospherical morphologies, and demonstrated a blue photoluminescence.

The various nitrogen-rich compounds were used as the precursors of N-g- $\mathrm{C}_{3} \mathrm{~N}_{4}$. Huynh et al. synthesized 3,6-di(azido)-1,2,4,5-tetrazine for obtaining nitrogen-rich carbon nitrides $C_{3} \mathrm{~N}_{4}$ and $\mathrm{C}_{3} \mathrm{~N}_{5}$ [47]. The high-nitrogen contained nitrides were also synthesized by thermal decomposition of 2,4,6-triazido-1,3,5-triazine [48], 2,5,8 triazido-s-heptazine [44-46]. However, these types of precursors are often thermodynamically unstable, shock and impact sensitive, and should be handled with caution.

Several groups reported on obtaining the nitrogen doped graphitic carbon nitride $\left(C_{3} \mathrm{~N}_{4+\mathrm{x}}\right)[49-52,62]$. Fang et al. performed the thermal condensation of precursor with hydrazine hydrate [49]. They confirmed that the nitrogen atom substitutes the $\mathrm{sp}^{2}$ carbon atom in the resultant $\mathrm{N}-\mathrm{g}-\mathrm{C}_{3} \mathrm{~N}_{4}$. According to EA the $\mathrm{N} / \mathrm{C}$ mass ratio was 1.68 for $\mathrm{C}_{3} \mathrm{~N}_{4+\mathrm{x}}$, that is, higher than that (1.60) of pristine $\mathrm{g}-\mathrm{C}_{3} \mathrm{~N}_{4}$.

$\mathrm{N}-\mathrm{g}-\mathrm{C}_{3} \mathrm{~N}_{4}$ with the high SSA was obtained by $\mathrm{Xu}$ et al. via secondary calcinations of $\mathrm{g}-\mathrm{C}_{3} \mathrm{~N}_{4}$ at different temperatures [50]. The highest nitrogen doping ratio and the largest SSA was observed for $\mathrm{g}-\mathrm{C}_{3} \mathrm{~N}_{4}$ that was post treated at $590^{\circ} \mathrm{C}$, which was confirmed with XPS, X-ray diffraction (XRD), and energy dispersion spectroscopy (EDS) methods. The XPS analysis allowed authors to conclude that the $\mathrm{sp}^{2} \mathrm{C}$ atom was replaced by the nitrogen atom. According to the EDS analysis, the highest value of $\mathrm{N}$ content in the $\mathrm{N}-\mathrm{g}-\mathrm{C}_{3} \mathrm{~N}_{4}$ was 57.57 at.\% and the lowest for undoped g- $\mathrm{C}_{3} \mathrm{~N}_{4}$ was 56.88 at.\%. The secondary calcination at $590{ }^{\circ} \mathrm{C}$ caused the SSA to increase of about 27 times (from 4.62 to 128.06 $\mathrm{m}^{2} \cdot \mathrm{g}^{-1}$ for non-treated and post thermal treated $\mathrm{g}-\mathrm{C}_{3} \mathrm{~N}_{4}$, respectively). The enhanced visible light absorption capacity was confirmed with UV-Vis DR spectra, which demonstrated the absorption edge red shift from $464 \mathrm{~nm}$ to $515 \mathrm{~nm}$ with the secondary calcination temperature increasing. The authors suggested that the shift was caused by the change of electronic structure due to the nitrogen doping. The bandgap of $g-\mathrm{C}_{3} \mathrm{~N}_{4}$ narrowed from 2.67 to $2.41 \mathrm{eV}$ after the secondary calcination step.

Jiang et al. used the same precursor as $\mathrm{Xu}$ et al. [50] for obtaining of $\mathrm{g}-\mathrm{C}_{3} \mathrm{~N}_{4}$, which they modified with N-N dimethylformamide (DMF) and then treated at $550{ }^{\circ} \mathrm{C}$ for $4 \mathrm{~h}$ under static air [52]. The SSA of g- $\mathrm{C}_{3} \mathrm{~N}_{4}$ modified with DMF (g-C $\mathrm{C}_{3} \mathrm{~N}_{4} / \mathrm{DMF}$ ) was $42.18 \mathrm{~m}^{2} \cdot \mathrm{g}^{-1}$ in comparison with $18.36 \mathrm{~m}^{2} \cdot \mathrm{g}^{-1}$ for non-treated g- $\mathrm{C}_{3} \mathrm{~N}_{4}$. The further increasing of the specific surface area to $74.79 \mathrm{~m}^{2} \cdot \mathrm{g}^{-1}$ was reached after the thermal treatment of $\mathrm{g}-\mathrm{C}_{3} \mathrm{~N}_{4}$ with DMF for $4 \mathrm{~h}$. The porous nanosheet architecture of $\mathrm{N}-\mathrm{g}-\mathrm{C}_{3} \mathrm{~N}_{4}$ caused the increasing of SSA confirmed with transmission electron microscopy (TEM) and atomic force microscopy (AFM). The C/N molar ratios were $0.692,0.679$, and 0.674 for the pristine $\mathrm{g}^{-} \mathrm{C}_{3} \mathrm{~N}_{4}$, g- $\mathrm{C}_{3} \mathrm{~N}_{4} / \mathrm{DMF}$, and exfoliated $\mathrm{N}-\mathrm{g}-\mathrm{C}_{3} \mathrm{~N}_{4}$, respectively. The authors proposed the copolymerization route of dicyandiamide and DMF. According to the XPS analysis the substitution of carbon with nitrogen was concluded to occur. The quantitative XPS analysis showed that the $\mathrm{C} / \mathrm{N}$ molar ratio of $\mathrm{N}-\mathrm{g}-\mathrm{C}_{3} \mathrm{~N}_{4}$ was 0.67 , and for pristine it was 0.76 . The $\mathrm{N}$ doping and nanosheet construction of $g-\mathrm{C}_{3} \mathrm{~N}_{4}$ expanded 
an absorption band of obtained materials and enhanced its ability to harvest visible light. The band gaps of pristine and $\mathrm{N}-\mathrm{g}-\mathrm{C}_{3} \mathrm{~N}_{4}$ were estimated to be $2.51 \mathrm{eV}$ and $2.54 \mathrm{eV}$, respectively. The transfer and separation efficiency of charge carries in N-g- $\mathrm{C}_{3} \mathrm{~N}_{4}$ materials were studied with PL spectroscopy. The decreasing of PL intensity of N-g- $\mathrm{C}_{3} \mathrm{~N}_{4}$ in comparison with $\mathrm{g}-\mathrm{C}_{3} \mathrm{~N}_{4}$ was explained by the presence of midgap states produced by the $\mathrm{N}$ doping. They served as separation centers to capture photoexcited electrons averting recombination processes.

Guo et al. synthesized N-doped porous g- $\mathrm{C}_{3} \mathrm{~N}_{4}$ with enhanced ability of photocatalytic $\mathrm{H}_{2}$ production through the one-step thermal copolymerization of urea and DMF [51]. No influence of DMF on the original graphitic C-N network was revealed with FTIR spectroscopy. According to XPS and EA $\mathrm{g}-\mathrm{C}_{3} \mathrm{~N}_{4}$, that which was obtained by the copolymerization of urea and DMF, was enriched with nitrogen. The results of ${ }^{13} \mathrm{C}$ nuclear magnetic resonance (NMR) and Raman analysis allowed the authors to conclude that the replacement of $\mathrm{C}$ atoms in triazine with $\mathrm{N}$ atoms occurred. The modification with DMF promoted the increasing of light absorption in visible region. The obvious red-shift of the absorption edge of $\mathrm{N}-\mathrm{g}-\mathrm{C}_{3} \mathrm{~N}_{4}$ was suggested to be the result of incorporated $\mathrm{N}$ atoms that caused increased delocalization of $\pi$-electrons. The analysis of UV-Vis DR spectra of $\mathrm{N}-\mathrm{g}-\mathrm{C}_{3} \mathrm{~N}_{4}$ revealed the narrowing of band gap to $2.69 \mathrm{eV}$ compared to $2.75 \mathrm{eV}$ of pristine g- $\mathrm{C}_{3} \mathrm{~N}_{4}$.

The supramolecular self-assembly strategy for obtaining of porous $\mathrm{N}-\mathrm{g}-\mathrm{C}_{3} \mathrm{~N}_{4}$ nanotubes with the high adsorption of $\mathrm{CO}_{2}$ was offered by Mo et al. [62]. In the first step, melamine and hydroxylammonium chloride were used to obtain a supramolecular intermediate at $120^{\circ} \mathrm{C}$ (Figure 3a). Secondly, the supramolecular intermediate was heated at $520^{\circ} \mathrm{C}$ under $\mathrm{NH}_{3}$, air, $\mathrm{Ar}$, and $\mathrm{N}_{2}$ atmospheres. From the scanning electron microscopy (SEM) analysis of $\mathrm{N}-\mathrm{g}-\mathrm{C}_{3} \mathrm{~N}_{4}$ obtained under the thermal treatment in various gases, the authors revealed the porous structure only in $\mathrm{g}^{-} \mathrm{C}_{3} \mathrm{~N}_{4}$ prepared under the $\mathrm{NH}_{3}$ atmosphere (Figure $3 \mathrm{~b}-\mathrm{d}$ ). The sharp increase of SSA was observed for the $\mathrm{N}-\mathrm{g}-\mathrm{C}_{3} \mathrm{~N}_{4}$ materials. The determined values of the SSA of bulk $\mathrm{g}-\mathrm{C}_{3} \mathrm{~N}_{4}$ and materials, which were obtained by treatment in $\mathrm{Ar}$, air, $\mathrm{N}_{2}$, and $\mathrm{NH}_{3}$, were $8.6,56.9,78.6,82.3$, and $108.9 \mathrm{~m}^{2} \cdot \mathrm{g}^{-1}$, respectively. The highest content of amino groups grafted into g- $\mathrm{C}_{3} \mathrm{~N}_{4}$ nanotubes during the time of the supramolecular intermediate polymerization process was observed for the porous materials treated under $\mathrm{NH}_{3}$ (g- $\mathrm{C}_{3} \mathrm{~N}_{4} / \mathrm{NH}_{3}$ ). The EA results indicated a significantly lower $\mathrm{C} / \mathrm{N}$ atomic ratio of g- $\mathrm{C}_{3} \mathrm{~N}_{4} / \mathrm{NH}_{3}$ than those of $\mathrm{g}-\mathrm{C}_{3} \mathrm{~N}_{4}$ samples synthesized under other atmospheres. The determined $\mathrm{C} / \mathrm{N}$ atomic ratio for the pristine $\mathrm{g}-\mathrm{C}_{3} \mathrm{~N}_{4}$ and materials obtained in $\mathrm{NH}_{3}, \mathrm{Ar}$, and $\mathrm{N}_{2}$, air were $0.69,0.55,0.59,0.58$, and $0.58 \mathrm{~m}^{2} \cdot \mathrm{g}^{-1}$, respectively. Based on the XPS analysis, the authors concluded that in the $\mathrm{NH}_{3}$ atmosphere, amino defects corresponding to terminal isolated amino groups were produced as a result of the opening of $\mathrm{C}-\mathrm{N}$ bonds. The influence of amino groups on the adsorption of $\mathrm{CO}_{2}$ and desorption of $\mathrm{CO}$ was studied with density functional theory (DFT) calculations. The DFT calculations demonstrated that $\mathrm{g}-\mathrm{C}_{3} \mathrm{~N}_{4} / \mathrm{NH}_{3}$ not only increased the $\mathrm{CO}_{2}$ adsorption energy, but also decreased the $\mathrm{CO}$ desorption energy that caused the higher photocatalytic $\mathrm{CO}_{2}$ reduction activity.

Hao at al. incorporated nitrogen atoms into g- $\mathrm{C}_{3} \mathrm{~N}_{4}$ by the hydrothermal treatment of exfoliated material using DMF [57] according to the scheme presented in Figure 4. The X-ray diffraction (XRD) and FTIR analysis of the obtained $2 \mathrm{D}$ g- $\mathrm{C}_{3} \mathrm{~N}_{4}$ nanosheets revealed that the basic characteristics of $g-\mathrm{C}_{3} \mathrm{~N}_{4}$ structure were not influenced by the surface nitrogen modification. Formation of new $\mathrm{C}-\mathrm{N}$ bonds due to $\mathrm{N}$ atoms insertion into the $\mathrm{g}-\mathrm{C}_{3} \mathrm{~N}_{4}$ lattice by filling of removed oxygen atom seats was confirmed by XPS. The authors distinguished three types of the $\mathrm{sp}^{2}$ hybridized nitrogen: Pyridinic nitrogen $(\mathrm{C}-\mathrm{N}=\mathrm{C})$, tertiary nitrogen $\left(\mathrm{N}-\mathrm{C}_{3}\right)$, and noncondensing amino group $(\mathrm{C}-\mathrm{N}-\mathrm{H})$, respectively. They confirmed the highest content of pyridinic $\mathrm{N}$ atoms in N-g- $\mathrm{C}_{3} \mathrm{~N}_{4}$ that is beneficial to the photocatalytic production of hydrogen. According to XPS, no new $\mathrm{N}-\mathrm{O}$ bonds were formed. The EDS elemental mapping allowed the authors to evidence the increased nitrogen content in the surface of $\mathrm{N}-\mathrm{g}-\mathrm{C}_{3} \mathrm{~N}_{4}$. The nitrogen-doped g- $\mathrm{C}_{3} \mathrm{~N}_{4}$ demonstrated enhanced visible absorption ability and the increasing lifetime of its excited state. 

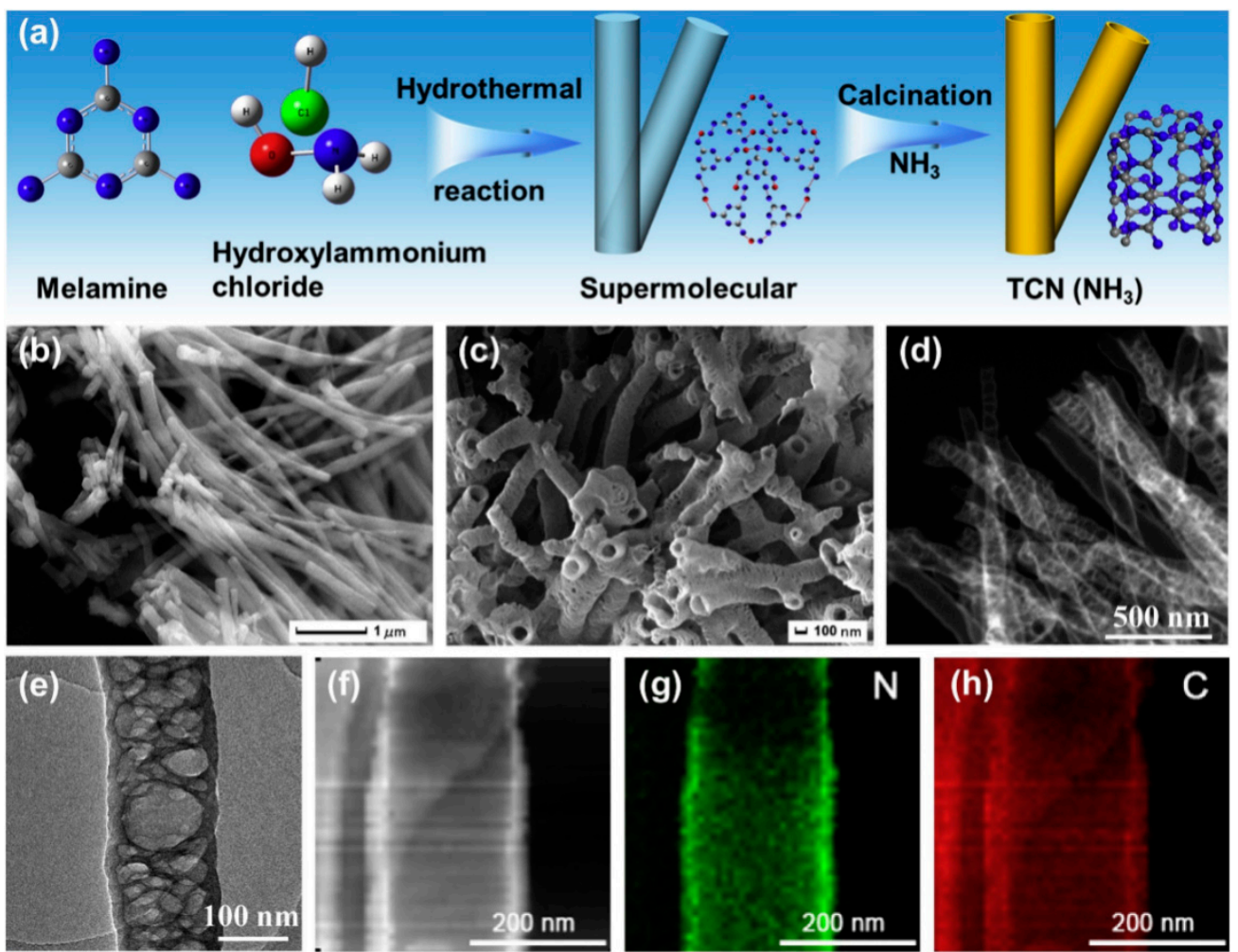

Figure 3. Formation and characterization of $\mathrm{g}-\mathrm{C}_{3} \mathrm{~N}_{4} / \mathrm{NH}_{3}$. Schematic illustration of the synthetic process (a), SEM images (b,c), TEM images (d,e), scanning tunneling electron microscopy (STEM) image (f), and energy dispersive $\mathrm{X}$-ray (EDX) maps of the $\mathrm{g}-\mathrm{C}_{3} \mathrm{~N}_{4} / \mathrm{NH}_{3}$ nanotubes $\left(\mathrm{TCN}\left(\mathrm{NH}_{3}\right)\right)(\mathbf{g}, \mathbf{h})$. Reprinted from [62], Copyright (2019), with permission from Elsevier.

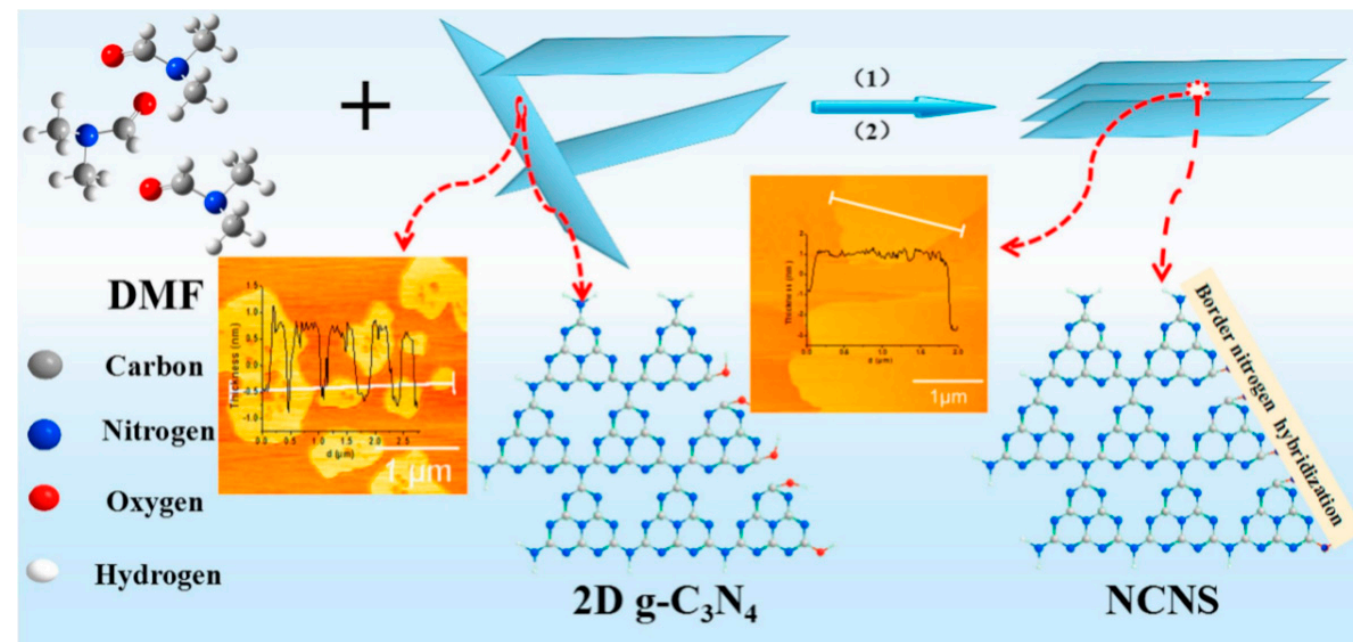

(1) heat treatment at $200^{\circ} \mathrm{C}$ in the oven (2) after (1), calcine in the muffle furnace

Figure 4. Scheme of the formation process from the bulk- $\mathrm{C}_{3} \mathrm{~N}_{4}$ to the $\mathrm{g}-\mathrm{C}_{3} \mathrm{~N}_{4}$ nanosheets (NCNS) sample. Reprinted from [57], Copyright (2018), with permission from Elsevier.

Amine-functionalized g- $\mathrm{C}_{3} \mathrm{~N}_{4}$ was obtained by its treatment with monoethanolamine (MEA) [58]. The ratio of amino groups in the treated sample was shown to be obviously higher due to the introduction of MEA molecules. Nearly the same absorption edges of amine-functionalized g- $\mathrm{C}_{3} \mathrm{~N}_{4}$ evidenced the absence of any doping effect and thus changes in the intrinsic electronic structure of g- $\mathrm{C}_{3} \mathrm{~N}_{4}$. The amine-functionalized materials demonstrated the increased adsorption of $\mathrm{CO}_{2}$ caused by the chemical interaction between $\mathrm{CO}_{2}$ and amino groups. The treatment of $\mathrm{g}-\mathrm{C}_{3} \mathrm{~N}_{4}$ with MEA resulted 
in the stronger adsorption of hydroxyl ions caused decreasing of zeta potentials in aqueous solutions. The zeta potential at $\mathrm{pH}=7$ of the amine-functionalized and pristine $\mathrm{g}-\mathrm{C}_{3} \mathrm{~N}_{4}$ were $-19.44 \mathrm{mV}$ and $-31.67 \mathrm{mV}$, respectively.

Yan et al. applied a $\mathrm{NH}_{4} \mathrm{Cl}$-assisted chemical blowing method to prepare nitrogen-rich graphitic carbon nitride nanosheets [59]. They revealed that under the thermal treatment of a $\mathrm{NH}_{4} \mathrm{Cl}$ and melamine mixture, generated gases detached $\mathrm{g}-\mathrm{C}_{3} \mathrm{~N}_{4}$ sheets from each other and decreased the polymerization of carbon nitride precursor subsequently forming nitrogen-doped nanosheets. The content of nitrogen in the obtained materials was higher (47.32 at.\%) in comparison with pristine g- $\mathrm{C}_{3} \mathrm{~N}_{4}$ (45.59 at.\%). The band gaps calculated from UV-Vis DR spectra increased from $2.73 \mathrm{eV}$ for $\mathrm{g}-\mathrm{C}_{3} \mathrm{~N}_{4}$ to $2.79 \mathrm{eV}$ for $\mathrm{N}-\mathrm{g}-\mathrm{C}_{3} \mathrm{~N}_{4}$. It was shown that the photoluminescence intensity of these materials was diminished when the morphology changed from bulky to nanosheet-like, due to suppression of electron-hole recombination in nanosheets.

Zhou et al. synthesized N-g- $\mathrm{C}_{3} \mathrm{~N}_{4}$ by the hydrothermal treatments of urea with small amount of citric acid [63]. The authors suggested that citric acid was a carbon source and promoted the formation of $\mathrm{N}-\mathrm{g}-\mathrm{C}_{3} \mathrm{~N}_{4}$ by the reaction with urea. Changes in the structure, SSA, and elemental compositions of obtained N-g- $\mathrm{C}_{3} \mathrm{~N}_{4}$ were not observed. $\mathrm{N}-\mathrm{g}-\mathrm{C}_{3} \mathrm{~N}_{4}$ demonstrated a little red shift of the intrinsic absorption edge in comparison with that of $\mathrm{g}-\mathrm{C}_{3} \mathrm{~N}_{4}$. The color of the materials changed from light to brown yellow with increase of the citric acid content in the reaction mixture. The authors suggested a lone pair electron on $\mathrm{g}^{-} \mathrm{C}_{3} \mathrm{~N}_{4}$ may trigger $\pi$-electron delocalization in this conjugated system. This material also demonstrated fluorescence quenching that evidenced the suppressed recombination of photogenerated charge carriers.

Wang et al. tried to dope $\mathrm{g}-\mathrm{C}_{3} \mathrm{~N}_{4}$ with nitrogen by the thermal polymerization of urea under the nitrogen atmosphere [53]. The obtained $\mathrm{N}-\mathrm{g}-\mathrm{C}_{3} \mathrm{~N}_{4}$ demonstrated the decreasing $\mathrm{C} / \mathrm{N}$ ratio 0.71 compared to 0.73 of $g-\mathrm{C}_{3} \mathrm{~N}_{4}$ as was revealed by the XPS analysis. The authors suggested that the decreasing of $\mathrm{C} / \mathrm{N}$ ratio in $\mathrm{N}-\mathrm{g}-\mathrm{C}_{3} \mathrm{~N}_{4}$ occurred due to the formation of carbon vacancies that promoted the formation of tri-s-triazine subunits. The intrinsic bandgaps of $\mathrm{N}-\mathrm{g}-\mathrm{C}_{3} \mathrm{~N}_{4}$ obtained in the nitrogen atmosphere increased to $2.70 \mathrm{eV}$ from $2.58 \mathrm{eV}$ of $\mathrm{g}-\mathrm{C}_{3} \mathrm{~N}_{4}$ obtained in air.

Tian et al. discovered that the pre-hydrothermal treatment of urea and melamine mixture (molar ratio of urea:melamine $=3: 1$ ) at $180^{\circ} \mathrm{C}$ promoted an irreversible monoclinic to orthorhombic melamine phase transformation, calcination of which caused the formation of mesoporous $\mathrm{g}^{-} \mathrm{C}_{3} \mathrm{~N}_{4}$ with enhanced photocatalytic activity [64]. The formation of ultrathin $\mathrm{N}-\mathrm{g}-\mathrm{C}_{3} \mathrm{~N}_{4}$ nanosheets with a thickness of $\sim 3 \mathrm{~nm}$ that consisted of 7 or 8 at. layers were confirmed with AFM. The SSA of $\mathrm{N}-\mathrm{g}-\mathrm{C}_{3} \mathrm{~N}_{4}$ was $39.1 \mathrm{~m}^{2} \cdot \mathrm{g}^{-1}$ with an average pore diameter of $46.1 \mathrm{~nm}$, which was 9 times higher than pristine $\mathrm{g}-\mathrm{C}_{3} \mathrm{~N}_{4}$. The introduction of $\mathrm{N}$ atoms into the $\mathrm{g}-\mathrm{C}_{3} \mathrm{~N}_{4}$ matrices was confirmed with the EA and XPS analyses. The band gap of $\mathrm{N}-\mathrm{g}-\mathrm{C}_{3} \mathrm{~N}_{4}$ decreased to $2.47 \mathrm{eV}$ in comparison with pristine g- $\mathrm{C}_{3} \mathrm{~N}_{4}(2.70 \mathrm{eV})$. The multiple reflection of incident light across the porous open network structure of the $\mathrm{N}$-rich materials caused their stronger light harvesting capability that appeared as enhanced photo-absorption below $450 \mathrm{~nm}$. 
Table 2. Synthetic methods, applications, and photocatalytic efficiency of N-doped g- $\mathrm{C}_{3} \mathrm{~N}_{4}$.

\begin{tabular}{|c|c|c|c|c|c|c|}
\hline Precursor & Synthetic Method & $\begin{array}{l}\text { C/N Atomic Ratio, } \\
\text { Doped (Pristine) }\end{array}$ & Photocatalytic Process & Conditions of the Process & Efficiency Doped/Pristine & References \\
\hline $\begin{array}{l}\text { Melamine, N-N } \\
\text { dimethylformamide } \\
\text { (DMF) }\end{array}$ & Hydrothermal treatment & $\begin{array}{l}0.407(0.540) \text { by EDS, } \\
0.457(0.575) \\
\text { by Organic Elemental } \\
\text { Analysis (OEA) }\end{array}$ & $\begin{array}{l}\mathrm{H}_{2} \\
\text { evolution }\end{array}$ & $\begin{array}{l}300 \mathrm{~W} \text { Xe lamp, filter } \lambda>400 \mathrm{~nm} \text { ), } \\
\text { co-catalysts Pt nanoparticles, } \\
\text { triethanolamine (TEOA) as a hole } \\
\text { quencher }\end{array}$ & $\begin{array}{l}128.5 \mathrm{~h}^{-1} \\
58.6 \mathrm{~h}^{-1}\end{array}$ & [57] \\
\hline $\begin{array}{l}\text { Melamine, hydrazine } \\
\text { hydrate }\end{array}$ & Thermal condensation & $\begin{array}{l}0.67(0.73) \text { by elemental } \\
\text { analysis }\end{array}$ & $\mathrm{H}_{2}$ evolution & $\begin{array}{l}300 \mathrm{~W} \text { Xe lamp, filter } \lambda>400 \mathrm{~nm}, \text { TEOA } \\
(10 \text { vol. } \% \text {, Pt co-catalyst }(3 \mathrm{wt} . \%)\end{array}$ & $\begin{array}{l}44.28 \mu \mathrm{mol} \cdot \mathrm{h}^{-1} / \\
7.86 \mu \mathrm{mol} \cdot \mathrm{h}^{-1}\end{array}$ & [49] \\
\hline dicyandiamide & Secondary calcination & 57.57 (56.88) at. $\%$ by EDS & $\begin{array}{l}\text { methylene blue } \\
\text { degradation }\end{array}$ & 300W Xe lamp, filter $\lambda>420 \mathrm{~nm}$ & $\begin{array}{l}0.02355 \mathrm{~min}^{-1} / \\
0.00829 \mathrm{~min}^{-1}\end{array}$ & {$[50]$} \\
\hline Dicyandiamide, DMF & Thermal copolymerization & $0.67(0.76)$ by XPS & $\begin{array}{l}\text { Tetracycline }(\mathrm{TC}) \\
\text { degradation }\end{array}$ & $300 \mathrm{~W}$ Xe lamp, filter $\lambda>420 \mathrm{~nm}$ & $\begin{array}{l}76.78(52.21) \% \text { of TC was } \\
\text { degraded in } 60 \text { min }\end{array}$ & [52] \\
\hline Urea, DMF & Thermal copolymerization & $\begin{array}{l}0.74(0.59) \text { at. } \% \text { by organic } \\
\text { elemental analysis }\end{array}$ & $\mathrm{H}_{2}$ evolution & $\begin{array}{l}300 \mathrm{~W} \text { Xe lamp, filter } \lambda>400 \mathrm{~nm}, \text { TEOA } \\
(10 \text { vol. } \%) \text {, Pt co-catalyst }(3 \mathrm{wt} . \%)\end{array}$ & $\begin{array}{l}5268 \mu \mathrm{mol} \mathrm{g}-1 \cdot \mathrm{h}^{-1 /} \\
3579 \mu \mathrm{mol} \mathrm{g} \\
-\mathrm{h}^{-1} /\end{array}$ & [51] \\
\hline $\begin{array}{l}\text { Urea, } \\
\text { monoethanolamine }\end{array}$ & $\begin{array}{l}\text { Amine functionalization of } \\
\mathrm{g}-\mathrm{C}_{3} \mathrm{~N}_{4}\end{array}$ & 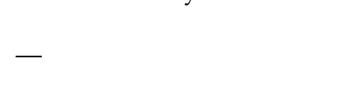 & $\mathrm{CO}_{2}$ reduction & 300W Xe lamp, gas phase reaction & $\begin{array}{l}\mathrm{CH}_{4}: 0.34 \mu \mathrm{mol} \cdot \mathrm{h}^{-1} \cdot \mathrm{g}^{-1} / \text { trace; } \\
\mathrm{CH}_{3} \mathrm{OH}: 0.26 \mu \mathrm{mol} \cdot \mathrm{h}^{-1} \cdot \mathrm{g}^{-1} / \\
0.26 \mu \mathrm{mol} \cdot \mathrm{h}^{-1} \cdot \mathrm{g}^{-1}\end{array}$ & [58] \\
\hline $\begin{array}{l}\text { Melamine, } \\
\mathrm{NH}_{4} \mathrm{Cl}\end{array}$ & Thermal polymerization & $\begin{array}{l}\mathrm{N} \text { content }(\text { at. } \%) \\
\text { doped } 47.32 \text { doped; } \\
45.59 \text { pristine }\end{array}$ & RhB degradation & 300W Xe lamp, $420 \mathrm{~nm}$ cutoff filter, & $\begin{array}{l}0.01954 \mathrm{~min}^{-1 /} \\
0.00391 \mathrm{~min}^{-1}\end{array}$ & [59] \\
\hline $\begin{array}{l}\text { Melamine, } \\
\mathrm{NH}_{4} \mathrm{Cl}\end{array}$ & $\begin{array}{l}\text { Second-calcination } \\
\text { approach }\end{array}$ & 1.14 (1.63) by XPS analysis & $\mathrm{H}_{2}$ evolution & $\begin{array}{l}\text { 420-nm LED, lactic acid (10 vol\%) } \\
\text { solution, (Pt co-catalyst }(1 \mathrm{wt} \%)\end{array}$ & $\begin{array}{l}15.5 \mathrm{mmol} \cdot \mathrm{h}^{-1} / \\
7.5 \mathrm{mmol} \cdot \mathrm{h}^{-1}\end{array}$ & [65] \\
\hline $\begin{array}{l}\text { Melamine, } \\
\mathrm{NH}_{4} \mathrm{Cl}\end{array}$ & $\begin{array}{l}\text { Precursor formation by } \\
\text { hydrothermal method; } \\
\text { thermal polymerization in } \\
\mathrm{NH}_{3}, \mathrm{~N}_{2}, \mathrm{Ar} \text {, air }\end{array}$ & $\begin{array}{l}0.55-0.59(0.69) \text { by } \\
\text { elemental analysis }\end{array}$ & $\mathrm{CO}_{2}$ reduction & $\begin{array}{l}300 \mathrm{~W} \text { Xe-lamp, } \mathrm{CoCl}_{2}, 2,2 \text {-bipyridine, } \\
\text { TEOA and methyl cyanide }\end{array}$ & $\begin{array}{l}103.6 \mu \mathrm{mol} \cdot \mathrm{g}^{-1} \cdot \mathrm{h}^{-1} / \\
6.1 \mu \mathrm{mol} \cdot \mathrm{g}^{-1} \cdot \mathrm{h}^{-1}\end{array}$ & {$[62]$} \\
\hline Citric acid, urea & Thermal polymerization & without change & $\mathrm{H}_{2}$ evolution & $\begin{array}{l}\text { 300W Xe lamp, } 420 \mathrm{~nm} \text { cutoff filter, } \\
\text { Pt nanoparticles ( } 3 \text { wt.\%), } \\
\text { triethanolamine as a hole quencher }\end{array}$ & $64 \mu \mathrm{mol} \cdot \mathrm{h}^{-1} / 15 \mu \mathrm{mol} \cdot \mathrm{h}^{-1}$ & [63] \\
\hline $\begin{array}{l}\text { Dicyandiamide, citric } \\
\text { acid, urea }\end{array}$ & Thermal polymerization & - & $\begin{array}{l}\text { Indomethacine } \\
\text { degradation }\end{array}$ & $\begin{array}{l}350 \mathrm{~W} \text { xenon lamp with } 420 \mathrm{~nm} \text { cutoff } \\
\text { filter; } 500 \mathrm{~W} \text { mercury lamp; } 350 \mathrm{~W} \text { xenon } \\
\text { lamp with a } 290 \mathrm{~nm} \text { cut-off filter }\end{array}$ & $\begin{array}{l}\text { Photocatalytic activity was } \\
1.1 \text { (UV light irradiation), } 1.8 \\
\text { (simulated sunlight), } \\
\text { and } 13.6 \text { (visible light } \\
\text { irradiation) times higher than } \\
\text { that of pristine g- } \mathrm{C}_{3} \mathrm{~N}_{4}\end{array}$ & [66] \\
\hline Melamine, urea & Hydrothermal treatment & $\begin{array}{l}\text { C: } N \text { mass ratio doped } \\
0.53 / 0.73 \text { by OEA; } \\
\text { C: } N \text { atomic ratio } 0.47 / 0.72 \\
\text { by quantitative XPS }\end{array}$ & $\mathrm{H}_{2}$ evolution & $\begin{array}{l}\text { 300W Xe lamp, } 420 \mathrm{~nm} \text { cutoff filter, } \\
\text { Pt nanoparticles (1 wt. } \%), 20 \% \text { vol. } \\
\text { lactic acid }\end{array}$ & $\begin{array}{l}3579 \mu \mathrm{mol} \cdot \mathrm{h}^{-1} \cdot \mathrm{g}^{-1} / \\
147 \mu \mathrm{mol} \cdot \mathrm{h}^{-1} \cdot \mathrm{g}^{-1}\end{array}$ & [64] \\
\hline Urea, $\mathrm{N}_{2}$ & Thermal polymerization & doped $0.71 / 0.73$ by XPS & $\begin{array}{l}\text { Bisphenol A oxidation; } \\
\text { Cr(VI) reduction }\end{array}$ & 300W Xe lamp, $420 \mathrm{~nm}$ cutoff filter & $\begin{array}{l}\text { Complete degradation of } \\
\text { BPA } 60 \text { min/ } 90 \text { min; } \\
\text { Photoreduction of Cr(VI) } \\
\text { over } 120 \text { min: } 10 \% / 60 \%\end{array}$ & [34] \\
\hline
\end{tabular}




\section{Carbon-Doped g- $\mathrm{C}_{3} \mathrm{~N}_{4}$}

It has been proposed that $\mathrm{g}-\mathrm{C}_{3} \mathrm{~N}_{4}$-carbonaceous compound hybrids can enhance visible-light absorption and improve photoinduced charge separation efficiency. The various allotropies and hetero-structures of carbon were used for incorporation into g- $\mathrm{C}_{3} \mathrm{~N}_{4}$ to optimize its conductivity and photocatalytic activity [67-79] (Table 3). The workable and effective way to design the surface structures and electronic properties of g- $\mathrm{C}_{3} \mathrm{~N}_{4}$ can also be provided by the self-doping of g- $\mathrm{C}_{3} \mathrm{~N}_{4}$ [80-87].

The carbon doped g- $\mathrm{C}_{3} \mathrm{~N}_{4}\left(\mathrm{C}-\mathrm{g}-\mathrm{C}_{3} \mathrm{~N}_{4}\right)$ composite was fabricated by Cao et al. in a facile one-pot way by the calcination of dicyanamide and small amounts of dimethylformamide as a cost-effective carbon source [71]. The increasing $\mathrm{C} / \mathrm{N}$ mass ratio determined by EA of 0.61 for $\mathrm{C}-\mathrm{g}-\mathrm{C}_{3} \mathrm{~N}_{4}$ in comparison with 0.59 for pristine $g-C_{3} \mathrm{~N}_{4}$ evidenced successful carbon incorporation. The substitution of $C$ atoms on original sites of bridging $\mathrm{N}$ was confirmed by the XPS study. The authors found that the content of bridging $\mathrm{N}$ in C-g- $\mathrm{C}_{3} \mathrm{~N}_{4}$ decreased from $17.28 \%$ to $16.95 \%$ due to replacement of bridging nitrogen by carbon atoms. $\mathrm{C}-\mathrm{g}-\mathrm{C}_{3} \mathrm{~N}_{4}$ contained the higher content of $\mathrm{C}-\mathrm{N}=\mathrm{C}$ groups $(71.17 \%)$ compared with pristine g- $\mathrm{C}_{3} \mathrm{~N}_{4}(70.75 \%)$, which benefited the formation of $\pi$-conjugated system. The C-doping caused a minor increasing of SSA from $16.63 \mathrm{~m}^{2} \cdot \mathrm{g}^{-1}$ for $\mathrm{g}-\mathrm{C}_{3} \mathrm{~N}_{4}$ to $17.80 \mathrm{~m}^{2} \cdot \mathrm{g}^{-1}$ for $\mathrm{C}$ doped $\mathrm{g}-\mathrm{C}_{3} \mathrm{~N}_{4}$. Typical semiconductor intrinsic absorption in UV range was observed for both $g-C_{3} \mathrm{~N}_{4}$. At the same time, the edge of $C-g-C_{3} N_{4}$ absorption band demonstrated some red shifts with respect to the pristine material. Additionally, remarkable enhancing of the absorption intensity of C-g- $\mathrm{C}_{3} \mathrm{~N}_{4}$ in visible-light region was observed. The values of band gap of pristine g- $C_{3} \mathrm{~N}_{4}$ and $\mathrm{C}-\mathrm{g}-\mathrm{C}_{3} \mathrm{~N}_{4}$ calculated by Tauc plots were $2.72 \mathrm{eV}$ and $2.66 \mathrm{eV}$, respectively. The values of conduction band (CB) determined with the photoelectrochemical method were $-1.21 \mathrm{~V}$ and $-0.94 \mathrm{~V}$ (vs. $\mathrm{Ag} / \mathrm{AgCl}$ electrode) for pristine $\mathrm{g}-\mathrm{C}_{3} \mathrm{~N}_{4}$ and C-g- $\mathrm{C}_{3} \mathrm{~N}_{4}$, respectively. The valence band (VB) of C-doped g- $\mathrm{C}_{3} \mathrm{~N}_{4} 1.92 \mathrm{eV}$ was shifted on $0.21 \mathrm{eV}$ with respect to g- $\mathrm{C}_{3} \mathrm{~N}_{4}(1.71 \mathrm{eV})$. The influence of C-doping on PL of g- $\mathrm{C}_{3} \mathrm{~N}_{4}$, which was originated from recombination of holes at valence band and electrons at conduction band, was studied. C-g- $\mathrm{C}_{3} \mathrm{~N}_{4}$ demonstrated the higher intensity of PL emission with respect to the pristine one. The authors concluded that C-g- $\mathrm{C}_{3} \mathrm{~N}_{4}$ behaves as an electron buffer that effectively speeds up excited electrons and delocalization of $\pi$-electrons in the conjugated system causing the separation ability of photo-excited holes and electrons. C-g- $\mathrm{C}_{3} \mathrm{~N}_{4}$ demonstrated 4.3 times higher photocurrent density compared with pristine $g-\mathrm{C}_{3} \mathrm{~N}_{4}$ under visible light.

A facile one-step thermal condensation method using an agar melamine gel (AMG) as the precursor was offered by Wang et al. to synthesize mesoporous C-g- $\mathrm{C}_{3} \mathrm{~N}_{4}$ ultrathin nanosheets (C/CNNS) [79]. The agar was applied as a soft template, which was carbonized between $g-\mathrm{C}_{3} \mathrm{~N}_{4}$ layers during the thermal polymerization. The ultrathin nanosheet structures and the typical wrinkled morphology was found on TEM images. The AFM analysis evidenced that C/CNNS consisted of approximately 10 single layers of $g-C_{3} N_{4}$. The absorption edge of $C / C N N S$ was shifted to the longer wavelengths with the increasing carbon content. Similarly, the color of the C/CNNS nanosheets was changed from light yellow to dark grey (Figure 5a). The values of band gap energies determined by the Tauc method were $2.62 \mathrm{eV}$ and $2.56 \mathrm{eV}$ for bulk g- $\mathrm{C}_{3} \mathrm{~N}_{4}$ and C/CNNS, respectively (Figure $5 \mathrm{~b}$ ). The CB edge potential $-0.61 \mathrm{eV}$ of $\mathrm{C} / \mathrm{CNNS}$ was negatively shifted in relation to the $\mathrm{CB}$ edge potential $-0.42 \mathrm{eV}$ of $\mathrm{g}-\mathrm{C}_{3} \mathrm{~N}_{4}$ (Figure $5 c, d$ ). The observed decreasing of PL intensity for C/CNNS compared to pristine $g-C_{3} N_{4}$ evidenced the suppressing of electron-hole pairs recombination induced by the carbon doping.

Ran et al. performed a simple thermal polymerization method to obtain C-g- $\mathrm{C}_{3} \mathrm{~N}_{4}$ photocatalysts with high NO removal efficiency under visible light [82]. C-g- $\mathrm{C}_{3} \mathrm{~N}_{4}$ prepared by the co-pyrolysis of urea and saccharose possessed high SSA: 81 and $118 \mathrm{~m}^{2} \cdot \mathrm{g}^{-1}$, for bulk and C-g- $\mathrm{C}_{3} \mathrm{~N}_{4}$, respectively. It improved the photocatalytic performance due to the formation of more active sites to assist the transfer of reactants. The substitution of $\mathrm{N}$ with $\mathrm{C}$ favored charge transportation and was observed by room temperature, solid-state electron paramagnetic resonance (EPR). The PL intensity greatly decreased with the increasing of carbon amount confirming that the carbon substitution suppressed photogenerated electron-hole recombination. The C-g- $\mathrm{C}_{3} \mathrm{~N}_{4}$ samples demonstrated improved visible-light absorption and narrowed band gap in comparison with pristine $\mathrm{g}-\mathrm{C}_{3} \mathrm{~N}_{4}$. The values of band gap were $2.71 \mathrm{eV}$ for 


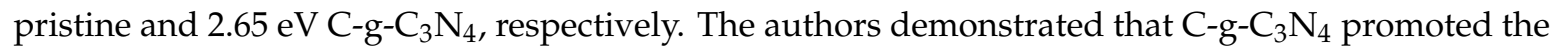
reactants activation, improved photo-generated charges separation, and assisted generation of radicals for the NO oxidation under visible light.
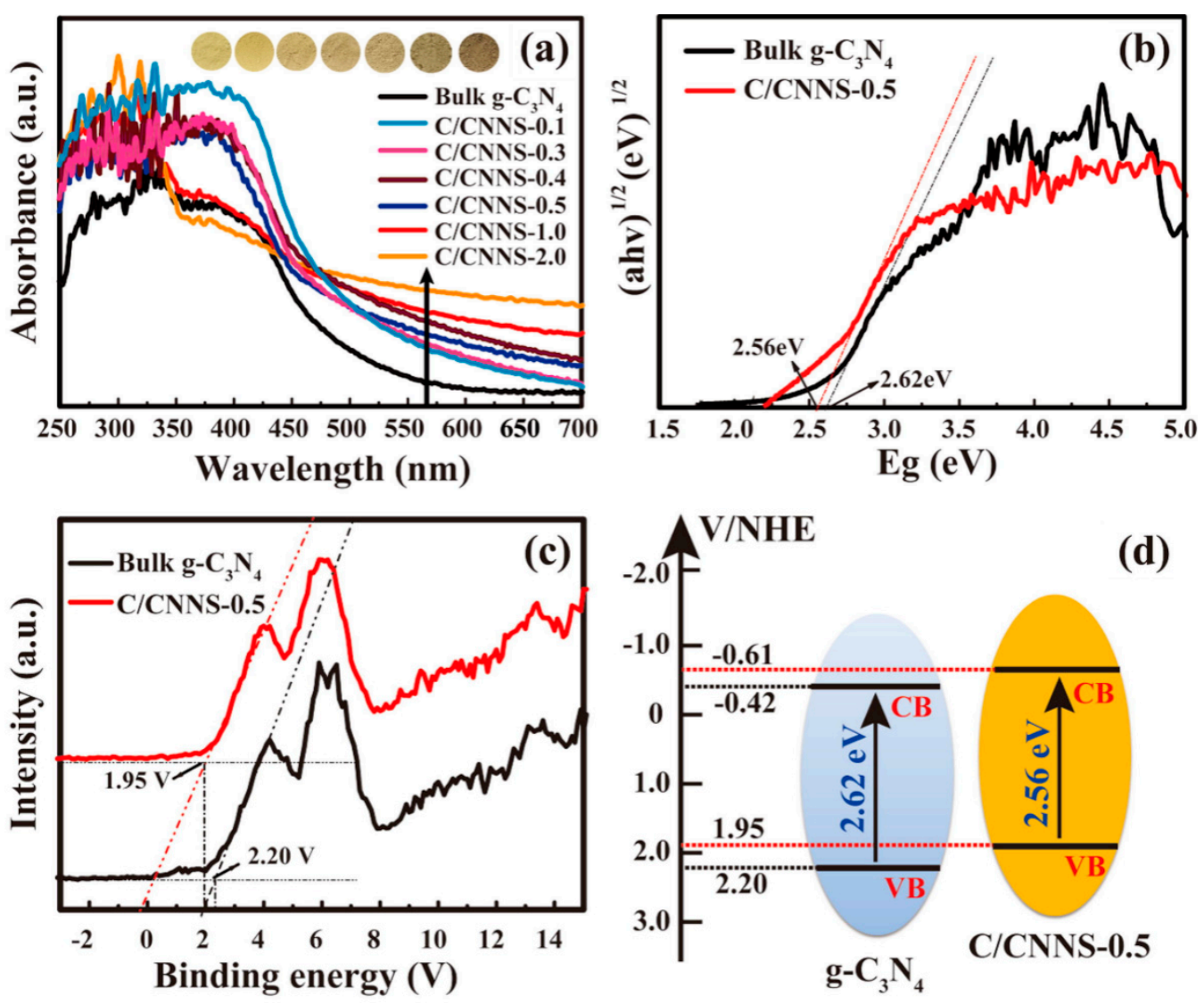

Figure 5. Ultra-violet diffuse-reflectance spectra of bulk g-C3N4, C/CNNS-x $(x=0.1,0.3,0.4,0.5,1.0,2.0)$ (a), the band gap plots (b), valence band (VB) XPS spectra (c), and the band structure diagrams of bulk g-C3N4 and C/CNNS-0.5 photocatalysts (d). Reprinted from [79], Copyright (2019), with permission from Elsevier.

Long et al. obtained $\mathrm{C}_{60} / \mathrm{g}-\mathrm{C}_{3} \mathrm{~N}_{4}$ nanowire composites for the photocatalytic $\mathrm{H}_{2}$ evolution process by the thermal treatment of urea and $\mathrm{C}_{60}$ nanorods mixture [76]. The insignificant increasing of SSA from $104.77 \mathrm{~m}^{2} \cdot \mathrm{g}^{-1}$ (for pristine $\mathrm{g}-\mathrm{C}_{3} \mathrm{~N}_{4}$ ) to $117.47 \mathrm{~m}^{2} \cdot \mathrm{g}^{-1}$ was observed. Both samples were mesoporous with the main pore width of $2-6 \mathrm{~nm}$. The incorporation of $\mathrm{C}_{60}$ nanorods in $\mathrm{g}^{-} \mathrm{C}_{3} \mathrm{~N}_{4}$ improved visible light absorbance. The band gap of the $\mathrm{C}_{60} / \mathrm{g}-\mathrm{C}_{3} \mathrm{~N}_{4}$ photocatalyst was narrower $(2.57 \mathrm{eV})$ compared to pristine g- $\mathrm{C}_{3} \mathrm{~N}_{4}(2.75 \mathrm{eV})$. The improved ability of $\mathrm{C}_{60} / \mathrm{g}-\mathrm{C}_{3} \mathrm{~N}_{4}$ to separate photogenerated electron-hole pairs was concluded from g- $\mathrm{C}_{3} \mathrm{~N}_{4}$ fluorescence quenching due to modification with $\mathrm{C}_{60}$. The $\mathrm{C}_{60} / \mathrm{g}-\mathrm{C}_{3} \mathrm{~N}_{4}$ nanocomposite produced more photogenerated electrons as demonstrated by the highest transient photocurrent responses compared to pristine g- $C_{3} N_{4}$. The improvement of $C_{60} / g-C_{3} N_{4}$ photocatalytic $\mathrm{H}_{2}$ production was explained by synergy of $\mathrm{g}-\mathrm{C}_{3} \mathrm{~N}_{4}$ and $\mathrm{C}_{60}$, which allowed the photogenerated charges separation. 
Table 3. Synthetic methods, applications, and photocatalytic efficiency of C-doped g- $\mathrm{C}_{3} \mathrm{~N}_{4}$.

\begin{tabular}{|c|c|c|c|c|c|c|}
\hline Precursor & Synthetic Method & $\begin{array}{c}\mathrm{C} / \mathrm{N} \\
\text { Doped (Pristine) }\end{array}$ & $\begin{array}{l}\text { Photocatalytic } \\
\text { Process }\end{array}$ & Conditions of the Process & Efficiency Doped/Pristine & Reference: \\
\hline $\begin{array}{l}\text { Dicyanamide, } \\
\text { dimethylformamide }\end{array}$ & $\begin{array}{c}\text { Thermal } \\
\text { copolymerization }\end{array}$ & $\begin{array}{c}\mathrm{C} / \mathrm{N} \text { mass ratio } \\
0.61(0.59) \text { by elemental } \\
\text { analysis }\end{array}$ & $\mathrm{H}_{2}$ evolution & $\begin{array}{c}\text { 300W Xe lamp, filter } \lambda>400 \mathrm{~nm}), \\
\text { Pt co-catalyst }(1 \mathrm{wt} . \%), \\
\text { triethanolamine (TEOA) as a } \\
\text { hole quencher }\end{array}$ & $\begin{array}{c}35.5 \mu \mathrm{mol} / \\
6.78 \mu \mathrm{mol} \text { in } 8 \mathrm{~h}\end{array}$ & [71] \\
\hline $\begin{array}{l}\text { Melamine, } \\
\text { cellulose }\end{array}$ & thermal treatment & $\begin{array}{c}\text { C/N mass ratio } \\
33.39 \text { (30.12) by elemental } \\
\text { analysis }\end{array}$ & $\mathrm{H}_{2}$ evolution & $\begin{array}{c}\text { 300W Xe lamp, filter } \lambda>420 \mathrm{~nm}) \text {, } \\
\mathrm{Pt}(3 \%) \text {, TEOA }(10 \mathrm{vol} \%)\end{array}$ & $\begin{array}{l}1024 \mu \mathrm{mol} \cdot \mathrm{g}^{-1} \cdot \mathrm{h}^{-1} / \\
59.6 \mu \mathrm{mol} \cdot \mathrm{g}^{-1} \cdot \mathrm{h}^{-1}\end{array}$ & [68] \\
\hline $\begin{array}{c}\text { Melamine, } \\
\text { Urea, } \\
\text { phenylmalonic acid }\end{array}$ & $\begin{array}{l}\text { Precursor } \\
\text { copolymerization on } \\
\text { the surface of } \mathrm{g}-\mathrm{C}_{3} \mathrm{~N}_{4}\end{array}$ & $\begin{array}{c}\text { C/N at. Ratio } \\
68.9(43.0) \\
\text { C, \% } \\
33.52 \text { (33.45) by elemental } \\
\text { analysis } \\
\text { C/N at. Ratio }\end{array}$ & $\begin{array}{l}\text { bisphenol A } \\
\text { (BPA) destruction } \\
\mathrm{H}_{2} \text { evolution }\end{array}$ & $\begin{array}{c}\text { 300W Xe lamp, filter } \lambda>420 \mathrm{~nm} \text {, } \\
\mathrm{Pt}(3 \%) \text {, TEOA }(10 \mathrm{vol} \%)\end{array}$ & $\begin{array}{c}\text { BPA destruction: } \\
0.0507 \mathrm{~min}^{-1 /} 0.0038 \mathrm{~min}^{-1} \\
\mathrm{H}_{2} \text { evolution: } \\
31 \mu \mathrm{mol} \cdot \mathrm{h}^{-1} / 10 \mu \mathrm{mol} \cdot \mathrm{h}^{-1}\end{array}$ & [73] \\
\hline $\begin{array}{l}\text { Cyanuric acid, } \\
\text { ethylene glycol, } \\
\text { melamine }\end{array}$ & $\begin{array}{l}\text { microwave treatment } \\
\text { of supramolecular } \\
\text { aggregates }\end{array}$ & $\begin{array}{c}0.688(0.669) \\
\text { C, \%: } \\
39.98 \text { (39.51) by elemental } \\
\text { analysis }\end{array}$ & $\mathrm{N}_{2}$ photofixation & $\begin{array}{l}\text { 250W high-pressure Na lamp } \\
(400<1<800 \mathrm{~nm})\end{array}$ & $\begin{array}{l}5.3 \mathrm{mg} \cdot \mathrm{L}^{-1} \cdot \mathrm{gcat}^{-1} / \\
0.48 \mathrm{mg} \cdot \mathrm{L}^{-1} \cdot \mathrm{gcat}^{-1}\end{array}$ & [88] \\
\hline Urea, $\mathrm{C}_{60}$ nanorods & $\begin{array}{c}\text { liquid-liquid } \\
\text { interfacial } \\
\text { precipitation method }\end{array}$ & 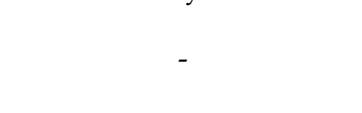 & $\mathrm{H}_{2}$ evolution & $\begin{array}{c}500 \mathrm{~W} \text { Xe lamp, filter } \lambda>420 \mathrm{~nm} \text {, } \\
\operatorname{Pt}(3 \%), \text { TEOA }(17 \mathrm{vol} \%)\end{array}$ & $\begin{array}{l}8.7 \mu \mathrm{mol} \cdot \mathrm{h}^{-1} / \\
1.85 \mu \mathrm{mol} \cdot \mathrm{h}^{-1}\end{array}$ & [76] \\
\hline Agar-melamine gel & $\begin{array}{l}\text { one-step thermal } \\
\text { condensation method }\end{array}$ & $\begin{array}{c}\text { C/N at. Ratio } \\
0.69(0.67) \\
\text { C, \%: } \\
34.9 \text { (35.33) by elemental } \\
\text { analysis } \\
\text { C/N at. Ratio } \\
0.90(0.87) \text { by XPS }\end{array}$ & $\begin{array}{l}\text { RhB, Phenol, BPA, } \\
\text { Phe destruction }\end{array}$ & $300 \mathrm{~W}$ Xe lamp, filter $\lambda>420 \mathrm{~nm}$ & $\begin{array}{l}\text { RhB destruction } \\
0.042 \mathrm{~min}^{-1} / \\
0.016 \mathrm{~min}^{-1} \\
\text { BPA destruction } \\
0.145 \mathrm{~min}^{-1} / \\
0.113 \mathrm{~min}^{-1}\end{array}$ & [79] \\
\hline Urea, sacharose & $\begin{array}{c}\text { Thermal } \\
\text { polymerization }\end{array}$ & $\begin{array}{c}\mathrm{C} / \mathrm{N} \text { at. Ratio } \\
0.58(0.57) \\
\mathrm{C}, \%: \\
34.83(34.81) \text { by XPS } \\
\text { analysis }\end{array}$ & NO removal & Xe lamp, filter $\lambda>420 \mathrm{~nm}$ & $\begin{array}{c}\text { NO removal ratio } 56.77 \% / \\
50.89 \%\end{array}$ & [82] \\
\hline $\begin{array}{l}\text { Melamine, carbon } \\
\text { dots (CD) }\end{array}$ & $\begin{array}{l}\text { combining g- } \mathrm{C}_{3} \mathrm{~N}_{4} \\
\text { treated with } \mathrm{H}_{2} \mathrm{O}_{2} \\
\text { and } \mathrm{CD}\end{array}$ & $\begin{array}{c}\text { C wt. \%: } \\
\text { 46.77(39.78) by EDX }\end{array}$ & $\begin{array}{l}\text { MB, RhB, fuchsine, } \\
\text { Phe destruction; } \\
\text { Cr(VI) } \\
\text { photoreduction }\end{array}$ & $\begin{array}{c}50 \mathrm{~W} \text { LED lamp, visible light } \\
\text { irradiation }\end{array}$ & $\begin{array}{l}\text { RhB destruction } \\
0.0675 \mathrm{~min}^{-1 /} \\
0.0019 \mathrm{~min}^{-1}\end{array}$ & [67] \\
\hline
\end{tabular}


The combination of carbon dots (CDs) with $\mathrm{g}-\mathrm{C}_{3} \mathrm{~N}_{4}\left(\mathrm{CDs} / \mathrm{g}-\mathrm{C}_{3} \mathrm{~N}_{4}\right)$ activated by hydrogen peroxide allowed Asadzadeh et al. to obtain photocatalysts with exceptional activity upon visible-light irradiation [67]. The activation of g- $\mathrm{C}_{3} \mathrm{~N}_{4}$ with $\mathrm{H}_{2} \mathrm{O}_{2}$ increased its SSA from 14.6 to $45.1 \mathrm{~m}^{2} \cdot \mathrm{g}^{-1}$ due to exfoliation during the treatment process. However, the adhering of CDs blocked micropores of the treated $\mathrm{g}-\mathrm{C}_{3} \mathrm{~N}_{4}$ that caused the SSA decrease to $19.7 \mathrm{~m}^{2} \cdot \mathrm{g}^{-1}$. The homogeneous dispersion of CDs on the surface of activated g- $\mathrm{C}_{3} \mathrm{~N}_{4}$ was confirmed by the EDS analysis. The EDS elemental mappings of $\mathrm{CDs} / \mathrm{g}-\mathrm{C}_{3} \mathrm{~N}_{4}$ demonstrated the uniform distribution of $\mathrm{C}, \mathrm{N}$, and $\mathrm{O}$ elements evidencing the binary nanocomposite formation. The presence of two components in $\mathrm{CDs} / \mathrm{g}-\mathrm{C}_{3} \mathrm{~N}_{4}$ was also confirmed by high-resolution TEM (HRTEM) images. The d-spacing of $\mathrm{g}-\mathrm{C}_{3} \mathrm{~N}_{4}$ was determined to be $0.326 \mathrm{~nm}$, corresponding to the lattice fringe of (002) planes, while the spacing of $0.320 \mathrm{~nm}$ corresponded to the (002) plane of CDs. The absorption band of the pristine $\mathrm{g}-\mathrm{C}_{3} \mathrm{~N}_{4}$ edge at $460 \mathrm{~nm}$ and was red shifted to $475 \mathrm{~nm}$ in the spectrum of the $\mathrm{H}_{2} \mathrm{O}_{2}$ activated g- $\mathrm{C}_{3} \mathrm{~N}_{4}$. The absorbance of CDs/g- $\mathrm{C}_{3} \mathrm{~N}_{4}$ demonstrated a slight shift to the visible region. The as-synthesized CDs demonstrated PL emissions located at $504 \mathrm{~nm}$ that shifted when excited by various wavelength lights (from 500 to $900 \mathrm{~nm}$ ). The authors suggested a multiphoton active process took place, in which absorption of two or more photons occurred simultaneously and caused emission of light at a shorter wavelength compared to the excitation wavelength. The PL study of $\mathrm{CDs} / \mathrm{g}-\mathrm{C}_{3} \mathrm{~N}_{4}$ was not reported. The thermal decomposition of the CDs/g- $\mathrm{C}_{3} \mathrm{~N}_{4}$ occurred at lower temperatures than that of pristine $\mathrm{g}-\mathrm{C}_{3} \mathrm{~N}_{4}$ due to the promoted exfoliation and integrated CDs.

\section{Sulfur-Doped g- $\mathrm{C}_{3} \mathrm{~N}_{4}$}

The doping of $\mathrm{g}-\mathrm{C}_{3} \mathrm{~N}_{4}$ with sulfur $\left(\mathrm{S}-\mathrm{g}-\mathrm{C}_{3} \mathrm{~N}_{4}\right.$ ) caused changes in its electronic structure, adjustment to the position of $\mathrm{CB}$ and $\mathrm{VB}$, carrier mobility enhancing, and as a result, improvement of photocatalytic activity (Table 4). The incorporation of $\mathrm{S}$ into $\mathrm{g}-\mathrm{C}_{3} \mathrm{~N}_{4}$ was performed by the thermal treatment under $\mathrm{H}_{2} \mathrm{~S}$ [89], the thermal polymerization of S-containing precursors [90-93], the thermal copolymerization with S-containing compounds [94-105], by a gas-templating method [106], and by sulfuring and treatment of $\mathrm{g}-\mathrm{C}_{3} \mathrm{~N}_{4}$ [107].

Li et al. applied thioacetamide (TAA) as a sulfur source for obtaining S-doped terminal-methylated g- $\mathrm{C}_{3} \mathrm{~N}_{4}$ (SM-g- $\mathrm{C}_{3} \mathrm{~N}_{4}$ ) nanosheets by a one-pot copolymerization process [103]. The thioacetamide also performed a blocking function during the polymerization to generate structure edge defects, which caused enlargement of SSA. The highest SSA of SM- $\mathrm{C}_{3} \mathrm{~N}_{4}$ was $90.5 \mathrm{~m}^{2} \cdot \mathrm{g}^{-1}$ compared to $42.6 \mathrm{~m}^{2} \cdot \mathrm{g}^{-1}$ of pristine $\mathrm{g}-\mathrm{C}_{3} \mathrm{~N}_{4}$. The XPS analysis revealed the increased C/N ratio in SM-g- $\mathrm{C}_{3} \mathrm{~N}_{4}(1.26)$ compared to $g-\mathrm{C}_{3} \mathrm{~N}_{4}(0.81)$ that the authors associated with methyl groups introducing. The increased number of the $\mathrm{C}-\mathrm{NH}_{\mathrm{x}}(\mathrm{x}=1,2)$ groups that were not involved in the polymerization due to a blocking effect of terminal methyl was confirmed with XPS. The remarkable shift of absorption edge to near-infrared region was observed in the UV-vis DR spectra of SM-g- $\mathrm{C}_{3} \mathrm{~N}_{4}$ samples with the increasing amount of TAA used for sulfur incorporation. The band gaps of SM-g- $C_{3} \mathrm{~N}_{4}$ nanosheets decreased from 2.62 (for $\mathrm{g}-\mathrm{C}_{3} \mathrm{~N}_{4}$ ) to $1.85 \mathrm{eV}$ (the optimum photocatalyst). The doping of sulfur into methylated melon units was confirmed with DFT calculation to promote the valence band splitting near the Fermi level and caused a midgap electronic state formation. As a result, a significant decrease of bandgap about $0.7 \mathrm{eV}$ occurred. The band structures of the $\mathrm{SM}-\mathrm{g}-\mathrm{C}_{3} \mathrm{~N}_{4}$ nanosheets were calculated based on the band gaps obtained from UV-vis DRS. The enhancement of non-radiative recombination rates after introducing sulfur and terminal methyl groups in melon was concluded from the PL study. From DFT calculations it was concluded that an internal electric field was formed due to changes in local charges allocation and lattices strain in melon units of $\mathrm{SM}-\mathrm{g}-\mathrm{C}_{3} \mathrm{~N}_{4}$ nanosheets and thus the separation of electron-hole pairs was improved.

$\mathrm{Lv}$ et al. combined doping of sulfur into g- $\mathrm{C}_{3} \mathrm{~N}_{4}$ in situ and thermal oxidative etching treatment of obtained S-g- $\mathrm{C}_{3} \mathrm{~N}_{4}$ [90]. The thermal oxidative etching caused the breaking of $\mathrm{H}$-bonds between layers of g- $\mathrm{C}_{3} \mathrm{~N}_{4}$ nanosheets and decreased their thickness to $4.0 \mathrm{~nm}$. S-g- $\mathrm{C}_{3} \mathrm{~N}_{4}$ nanosheets treated over $3 \mathrm{~h}$ demonstrated increased SSA to $226.9 \mathrm{~m}^{2} \cdot \mathrm{g}^{-1}$ compared to $16.6 \mathrm{~m}^{2} \cdot \mathrm{g}^{-1}$ for pristine $\mathrm{g}^{-} \mathrm{C}_{3} \mathrm{~N}_{4}$. 
An apparent blue shift of absorption band edge from 470 to $420 \mathrm{~nm}$ was demonstrated compared to pristine $\mathrm{g}-\mathrm{C}_{3} \mathrm{~N}_{4}$. However, in comparison with the analog without sulfur, the absorption band edge of S-g- $C_{3} N_{4}$ nanosheets was red-shifted by 5-10 nm. The band gap of pristine g- $C_{3} N_{4}$ and the nanosheets with and without S-doping was calculated to be $2.28,2.73$, and $2.85 \mathrm{eV}$. The mass percent of the $S$ atom in the samples estimated by XPS demonstrated that thermal oxidative etching treatment caused the increased $S$ content in g- $C_{3} N_{4}$. The content of $S$ in the S-g- $C_{3} N_{4}$ nanosheets and S-g- $C_{3} N_{4}$ was calculated to be 1.58 and $0.51 \mathrm{wt} . \%$, respectively. The analysis of the $\mathrm{O} / \mathrm{C}$ and N/C ratios in the S-g- $\mathrm{C}_{3} \mathrm{~N}_{4}$ before and after oxidative etching treatment revealed the formation of more surface $\mathrm{O}$ species and surface $\mathrm{N}$ defects after the etching treatment. It was also suggested that the doping of sulfur was favorable to the formation of surface $\mathrm{N}$ defects and $\mathrm{O}$ species. The S-g- $\mathrm{C}_{3} \mathrm{~N}_{4}$ nanosheets demonstrated highest capability for the separation of photogenerated charge carrier and this material was stable for up to $36 \mathrm{~h}$ during the photocatalytic $\mathrm{H}_{2}$ evolution.

Ke et al. synthesized the graphene-like S-g- $\mathrm{C}_{3} \mathrm{~N}_{4}$ by the thermal treatment of a urea and benzyl disulfide mixture at $560-650{ }^{\circ} \mathrm{C}$ in the Ar flow [101]. The pronounced increase of SSA was observed from $20.2 \mathrm{~m}^{2} \cdot \mathrm{g}^{-1}$ of pristine $\mathrm{g}-\mathrm{C}_{3} \mathrm{~N}_{4}$ to $298.2 \mathrm{~m}^{2} \cdot \mathrm{g}^{-1}$ of S-g- $\mathrm{C}_{3} \mathrm{~N}_{4}$. The XPS analysis allowed the authors to evidence the formation of $\mathrm{C}-\mathrm{S}$ bonding by replacing the latticed $\mathrm{N}$ with $\mathrm{S}$, and the presence of $\mathrm{C}-\mathrm{SO}_{\mathrm{x}}-\mathrm{C}$ bond. The transformation of $\mathrm{g}-\mathrm{C}_{3} \mathrm{~N}_{4}$ to graphene-like S-g- $\mathrm{C}_{3} \mathrm{~N}_{4}$ was achieved by weakening planar H-bonding when $S$ partially replaced $N$. An obvious red shift of the absorption edges of $S-g-C_{3} N_{4}$ to $530 \mathrm{~nm}$ compared with that of $\mathrm{g}-\mathrm{C}_{3} \mathrm{~N}_{4}$ at $458 \mathrm{~nm}$ was observed (Figure 6a). Accordingly, the band gap energy decreased from $2.74 \mathrm{eV}\left(\mathrm{g}-\mathrm{C}_{3} \mathrm{~N}_{4}\right)$ to $2.10 \mathrm{eV}\left(\mathrm{S}-\mathrm{g}-\mathrm{C}_{3} \mathrm{~N}_{4}\right)$ (Figure 6b). The calculation of band potentials of the samples vs. standard hydrogen electrode evidenced the formation of electronic structures with the elevated CB and VB potentials in S-g- $\mathrm{C}_{3} \mathrm{~N}_{4}$ (Figure 6c). The as-designed S-g- $\mathrm{C}_{3} \mathrm{~N}_{4}$ demonstrated the high photocatalytic elimination efficiency of $\mathrm{UO}_{2}{ }^{2+}$ under visible-light illumination. The narrowed band gap with upshifting of $\mathrm{CB}$ and VB potentials, and the excellent efficiency of charge transfer and carrier utilization, caused the remarkable photoactivity of S-g- $\mathrm{C}_{3} \mathrm{~N}_{4}$.

Fan et al. constructed S-g- $\mathrm{C}_{3} \mathrm{~N}_{4}$ rods with increased SSA and tuned their band gap to enhance photocatalytic activity [95]. They conducted the pyrolysis of supramolecular melamine-trithiocyanuric acid complexes (MT) at $500-650{ }^{\circ} \mathrm{C}$ (Figure 7). S-g- $\mathrm{C}_{3} \mathrm{~N}_{4}$ demonstrated the increased SSA of $52 \mathrm{~m}^{2} \cdot \mathrm{g}^{-1}$ compared to pristine $\mathrm{g}-\mathrm{C}_{3} \mathrm{~N}_{4}\left(15 \mathrm{~m}^{2} \cdot \mathrm{g}^{-1}\right)$. The composition study by the elemental analysis showed similar atomic $\mathrm{C} / \mathrm{N}$ ratios (0.67-0.69) of S-g- $\mathrm{C}_{3} \mathrm{~N}_{4}$ with that of pristine $\mathrm{g}-\mathrm{C}_{3} \mathrm{~N}_{4}(0.65)$. The presence of about $2 \%$ of hydrogen in pristine $g-\mathrm{C}_{3} \mathrm{~N}_{4}$ was attributed to the un-condensed amino groups. With the increasing temperature of the treatment, the $\mathrm{H}$ content decreased due to the higher condensation yield. The content of $\mathrm{S}$ in S-g- $\mathrm{C}_{3} \mathrm{~N}_{4}$ decreased from 0.63 to $0.27 \mathrm{wt} . \%$ with the increasing synthesis temperature. The sulfur oxide species formed during the calcination were found. The improved optical absorption in the range of $450-600 \mathrm{~nm}$ was observed for all S-g- $\mathrm{C}_{3} \mathrm{~N}_{4}$ rods. The corresponding band gaps estimated from the absorption spectra decreased after the S-doping from $2.70 \mathrm{eV}$ of pristine g- $\mathrm{C}_{3} \mathrm{~N}_{4}$ to $2.56 \mathrm{eV}$ of S-g- $\mathrm{C}_{3} \mathrm{~N}_{4}$. The decreasing of fluorescence intensity was observed for S-g- $\mathrm{C}_{3} \mathrm{~N}_{4}$ evidencing enhancement of the separation efficiency of photogenerated electron-hole pairs. The S-g- $\mathrm{C}_{3} \mathrm{~N}_{4}$ rods demonstrated the high adsorption and photocatalytic activity on the $\mathrm{RhB}$ decomposition under visible light. 

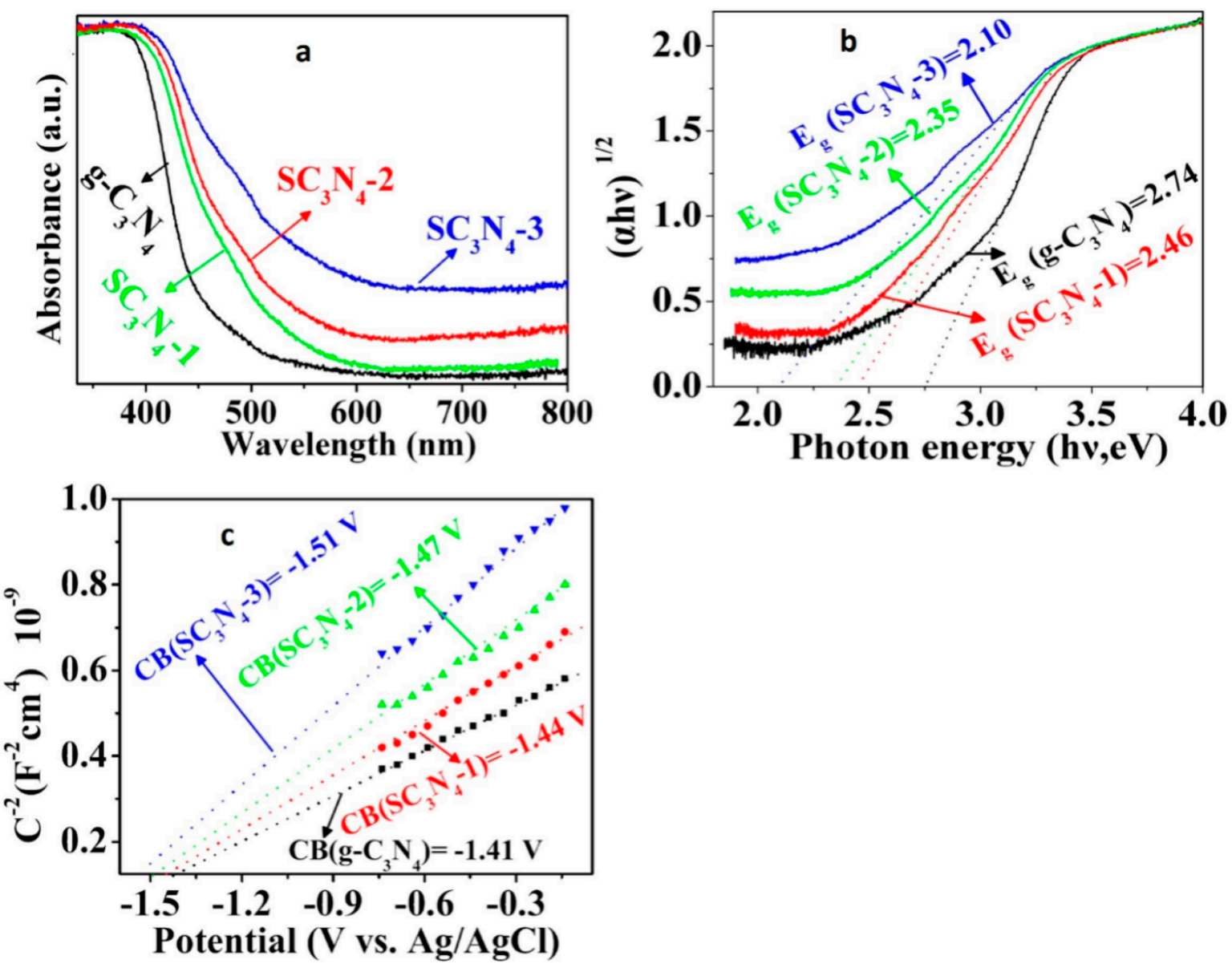

Figure 6. Optical absorption spectra of $g-\mathrm{C}_{3} \mathrm{~N}_{4}$ and S-g- $\mathrm{C}_{3} \mathrm{~N}_{4}\left(\mathrm{SC}_{3} \mathrm{~N}_{4}\right)$ samples (a); plots of $(\alpha \mathrm{hv})^{1 / 2} \mathrm{vs}$. photon energy (hv) (b) and electrochemical Mott-Schottky plots of $g-\mathrm{C}_{3} \mathrm{~N}_{4}$ and S-g- $\mathrm{C}_{3} \mathrm{~N}_{4}$ samples (c). Reprinted from [101] Copyright (2017), with permission from Elsevier.

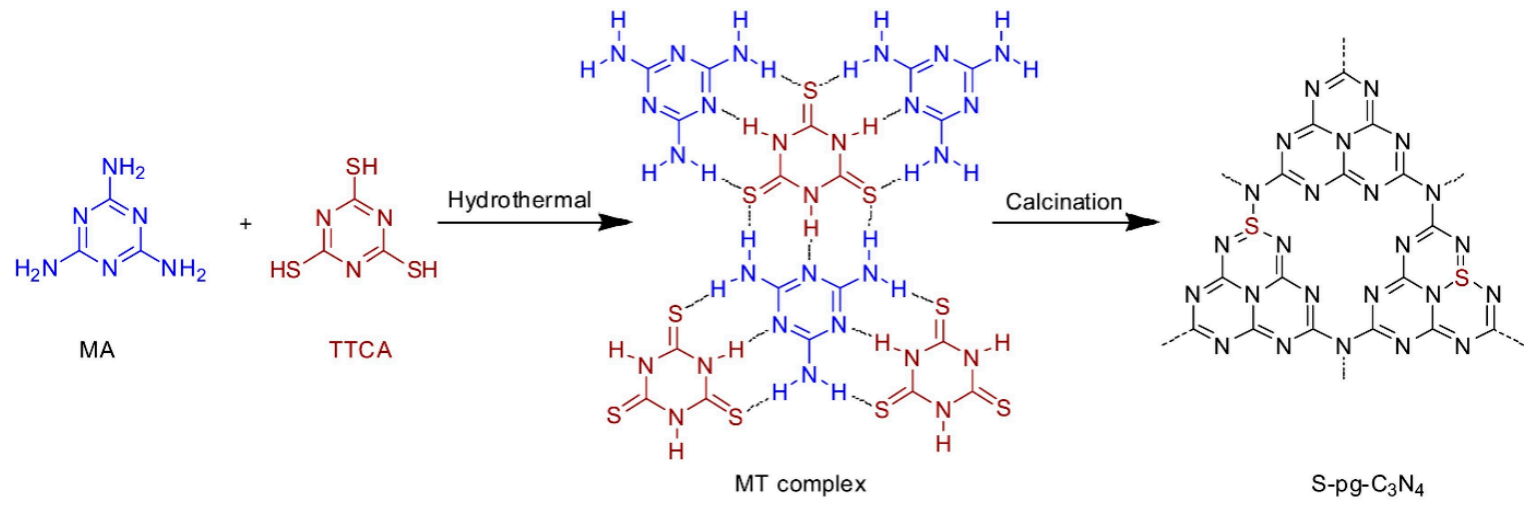

Figure 7. Scheme of the formation of melamine-trithiocyanuric acid (MT) complex and S-g- $\mathrm{C}_{3} \mathrm{~N}_{4}$. Reprinted from [95] Copyright (2017), with permission from Elsevier. 
Table 4. Synthetic methods, applications, and photocatalytic efficiency of S-doped $g-C_{3} \mathrm{~N}_{4}$.

\begin{tabular}{|c|c|c|c|c|c|c|}
\hline Precursor & Synthetic Method & Content of Sulfur & $\begin{array}{l}\text { Photocatalytic } \\
\text { Process }\end{array}$ & Conditions of the Process & Efficiency Doped/Pristine & References \\
\hline Melamine, sulfur & $\begin{array}{l}\text { Thermal } \\
\text { polycondensation, } 520^{\circ} \mathrm{C}\end{array}$ & - & $\begin{array}{l}\mathrm{O}_{2} \text { evolution; } \\
\text { scheme } \mathrm{H}_{2} \mathrm{O} \text { splitting; } \\
\text { bactericidal activity }\end{array}$ & $\begin{array}{c}400 \mathrm{~W} \text { halide lamp }\left(\lambda_{\max }=360\right. \\
\mathrm{nm}), 150 \mathrm{~W} \text { Xe lamp, filter } \lambda>400 \\
\mathrm{~nm} \\
{\left[\mathrm{Co}(\text { bpy })_{3}\right]_{\mathrm{SO}_{4}} \text { as electron }} \\
\text { mediator, } \mathrm{Ru} / \mathrm{SrTiO}_{3}: \mathrm{Rh} \text { as } \\
\text { cocatalyst }\end{array}$ & $\begin{array}{c}\mathrm{O}_{2} \text { evolution: } \\
40.3 \mu \mathrm{mol} \cdot \mathrm{h}^{-1} /- \\
\text { Z-scheme } \mathrm{H}_{2} \mathrm{O} \text { splitting: } \\
29.3 \mu \mathrm{mol} \cdot \mathrm{h}^{-1} /-; \\
70 \% \text { of bacteria were killed }\end{array}$ & [96] \\
\hline $\begin{array}{l}\text { Melamine, } \\
\left(\mathrm{NH}_{4}\right)_{2} \mathrm{SO}_{4}\end{array}$ & $\begin{array}{l}\text { Upgraded gas templating } \\
\text { method }\end{array}$ & - & $\mathrm{H}_{2}$ evolution & $\begin{array}{c}350 \mathrm{~W} \text { Xe lamp, filter } \lambda>420 \mathrm{~nm}, \\
10 \% \text { vol\% TEOA, Pt co-catalyst }(1 \\
\text { wt. } \%)\end{array}$ & $\begin{array}{l}572 \mu \mathrm{mol} \cdot \mathrm{h}^{-1} \cdot \mathrm{g}^{-1} / \\
78 \mu \mathrm{mol} \cdot \mathrm{h}^{-1} \cdot \mathrm{g}^{-1}\end{array}$ & {$[106]$} \\
\hline $\begin{array}{l}\text { Urea, } \\
\text { thioacetamide }\end{array}$ & $\begin{array}{l}\text { One-pot } \\
\text { copolymerization }\end{array}$ & $\begin{array}{l}0.1 \text { at. } \% \mathrm{~S} \\
0.2 \text { by XPS }\end{array}$ & $\begin{array}{l}\text { Procion Red MX-5B } \\
\text { degradation } \\
\mathrm{H}_{2} \text { evolution }\end{array}$ & $\begin{array}{c}500 \mathrm{~W} \text { Xe lamp, monochromic light } \\
\text { provided by using a } 420 \pm 15,450 \\
\pm 15,475 \pm 15 \text { and } 520 \pm 15 \mathrm{~nm} \\
\text { band pass filter } \\
\text { TEOA, Pt co-catalyst ( } 1 \mathrm{wt} . \%)\end{array}$ & $\begin{array}{c}\text { Dye degradation } \\
0.072 \mathrm{~min}^{-1} / 0.024 \mathrm{~min}^{-1} \\
\mathrm{H}_{2} \text { evolution } \\
3.17 \mathrm{mmol} \cdot \mathrm{g}^{-1} \cdot \mathrm{h}^{-1} / \\
0.84 \mathrm{mmol} \cdot \mathrm{g}^{-1} \cdot \mathrm{h}^{-1}\end{array}$ & [103] \\
\hline Thiourea & $\begin{array}{l}\text { Thermal } \\
\text { polycondensation } \\
\text { followed by thermal } \\
\text { oxidative etching }\end{array}$ & $\begin{array}{c}\text { S content: } 0.45 \text { by OEA, } \\
1.58 \text { by XPS }\end{array}$ & $\begin{array}{c}\text { Phenol degradation; } \\
\mathrm{H}_{2} \text { evolution }\end{array}$ & $\begin{array}{c}300 \mathrm{~W} \text { Xe lamp, } 5 \% \text { vol } \% \text { TEOA, Pt } \\
\text { co-catalyst (1 wt.\%) }\end{array}$ & $\begin{array}{l}75 \% / 100 \% \text { of Phenol was } \\
\text { decomposed; } \\
\mathrm{H}_{2} \text { evolution: } \\
127.4 \mu \mathrm{mol} \cdot \mathrm{h}^{-1} / \\
0.5 \mu \mathrm{mol} \cdot \mathrm{h}^{-1}\end{array}$ & [90] \\
\hline $\begin{array}{l}\text { Thiourea, mesyl } \\
\text { chloride }\end{array}$ & $\begin{array}{l}\text { Post-synthetic } \\
\text { derivatization of } \\
\text { g- } \mathrm{C}_{3} \mathrm{~N}_{4}\end{array}$ & - & $\begin{array}{l}\text { Acid Orange } 7 \text { dye } \\
\text { degradation }\end{array}$ & UVA tube lamp, $\lambda_{\max }=368 \mathrm{~nm}$ & $0.113 \mathrm{~min}^{-1} / 0.022 \mathrm{~min}^{-1}$ & [99] \\
\hline $\begin{array}{l}\text { 1,3,5-trichlorotriazine, } \\
\text { Melamine, } \\
\text { Trithiocyanuric acid }\end{array}$ & $\begin{array}{l}\text { Solvothermal } \\
\text { condensation process, } 180 \\
{ }^{\circ} \mathrm{C}\end{array}$ & - & $\mathrm{Cr}(\mathrm{VI})$ reduction & Irradiation with $\lambda>420 \mathrm{~nm}$ & $1.85 \mathrm{~min}^{-1} / 0.03 \mathrm{~min}^{-1}$ & [104] \\
\hline $\begin{array}{l}\text { Melamine, } \\
\text { Trithiocyanuric acid }\end{array}$ & $\begin{array}{l}\text { Thermal } \\
\text { polycondensation of the } \\
\text { supramolecular complex }\end{array}$ & $S(w t \%): 0.63$ & RhB degradation & $500 \mathrm{~W}$ Xe lamp, filter $\lambda>420 \mathrm{~nm}$ & $0.0167 \mathrm{~min}^{-1} / 0.0013 \mathrm{~min}^{-1}$ & [95] \\
\hline $\begin{array}{l}\text { Urea, benzyl } \\
\text { disulfide }\end{array}$ & $\begin{array}{l}\text { Thermal } \\
\text { polycondensation, } 520^{\circ} \mathrm{C}\end{array}$ & - & $\begin{array}{l}\text { Reduction } \\
\text { elimination of } \mathrm{UO}_{2}{ }^{2+}\end{array}$ & $350 \mathrm{~W}$ Xe lamp, $\lambda \geq 420 \mathrm{~nm}$ & $0.16 \mathrm{~min}^{-1} / 0.07 \mathrm{~min}^{-1}$ & [101] \\
\hline Urea, thiourea & $\begin{array}{l}\text { Thermal } \\
\text { polycondensation, } 550^{\circ} \mathrm{C}\end{array}$ & - & $\mathrm{H}_{2}$ evolution & $\begin{array}{c}300 \mathrm{~W} \text { Xe lamp, filter } \lambda>420 \mathrm{~nm}, \\
10 \% \text { vol } \% \text { TEOA }\end{array}$ & $\begin{array}{l}95.3 \mu \mathrm{mol} \cdot \mathrm{h}^{-1} / \\
36.4 \mu \mathrm{mol} \cdot \mathrm{h}^{-1}\end{array}$ & {$[100]$} \\
\hline $\begin{array}{l}\text { Melamine, sulfuric } \\
\text { acid }\end{array}$ & $\begin{array}{l}\text { Sulfuring and sonicating } \\
\text { bulk } g-C_{3} N_{4}\end{array}$ & - & $\begin{array}{l}\text { 4-nitrophenol } \\
\text { degradation }\end{array}$ & $500 \mathrm{~W}$ Xe lamp, filter $\lambda>400 \mathrm{~nm}$ & $\begin{array}{l}3.47 \times 10^{-2} \mathrm{~min}^{-1} / \\
7.04 \times 10^{-4} \mathrm{~min}^{-1}\end{array}$ & [107] \\
\hline Thiourea & $\begin{array}{l}\text { Thermal } \\
\text { polycondensation, } 520^{\circ} \mathrm{C}\end{array}$ & S atomic $\% 0.05$ by EA & $\mathrm{CO}_{2}$ reduction & $\begin{array}{c}300 \mathrm{~W} \text { Xe lamp, Pt co-catalyst } \\
(1 \mathrm{wt.} \%)\end{array}$ & $\begin{array}{c}\mathrm{CH}_{3} \mathrm{OH} \text { formation: } \\
1.12 \mu \mathrm{mol} \cdot \mathrm{g}^{-1} / 0.81 \mu \mathrm{mol} \cdot \mathrm{g}^{-1}\end{array}$ & [98] \\
\hline
\end{tabular}




\section{P-Doped g- $\mathrm{C}_{3} \mathrm{~N}_{4}$}

To overcome the inherent drawbacks of $\mathrm{g}_{-} \mathrm{C}_{3} \mathrm{~N}_{4}$ and to promote its photocatalytic activity, the doping of phosphorus into g- $\mathrm{C}_{3} \mathrm{~N}_{4}\left(\mathrm{P}-\mathrm{g}-\mathrm{C}_{3} \mathrm{~N}_{4}\right)$ was performed recently by many researchers [108-121]. The band gap structure regulation and the improvement of carrier separation efficiency were reached (Table 5). The most commonly used method for obtaining of $\mathrm{P}-\mathrm{g}-\mathrm{C}_{3} \mathrm{~N}_{4}$ was the thermal modification of pristine g- $\mathrm{C}_{3} \mathrm{~N}_{4}$ with sources of $\mathrm{P}[109,115,117]$ and their thermal condensation [108,110,118,119,122-124].

$\mathrm{Su}$ et al. performed the thermal condensation of adenosine phosphate and urea followed by thermal exfoliation to obtain porous P-g- $\mathrm{C}_{3} \mathrm{~N}_{4}$ nanosheets [118]. The increasing of SSA to $84.8 \mathrm{~m}^{2} \cdot \mathrm{g}^{-1}$ was reached compared to $66.6 \mathrm{~m}^{2} \cdot \mathrm{g}^{-1}$ of pristine $\mathrm{g}-\mathrm{C}_{3} \mathrm{~N}_{4}$. The XPS analysis indicated the presence of $\mathrm{P}$ in the nanosheets in terms of $\mathrm{P}=\mathrm{N}$ and $\mathrm{P}-\mathrm{N}$ bonds. According to EA the content of $\mathrm{P}$ was 2.17 atomic\%. The lower $\mathrm{C} / \mathrm{N}$ ratio of 0.71 of $\mathrm{P}-\mathrm{g}-\mathrm{C}_{3} \mathrm{~N}_{4}$ compared to 0.75 of pristine $\mathrm{g}-\mathrm{C}_{3} \mathrm{~N}_{4}$ was observed. The increasing of the $\mathrm{O}$ atomic $\%$ from $2.8 \%$ of pristine to $7.65 \%$ of the $\mathrm{P}-\mathrm{g}-\mathrm{C}_{3} \mathrm{~N}_{4}$ nanosheets was ascribed to the higher content of $\mathrm{C}-\mathrm{OH}$ bonds in the edge of $\mathrm{g}-\mathrm{C}_{3} \mathrm{~N}_{4}$ as a result of the thermal exfoliation. The authors suggested the replacement of $C$ atoms with $P$ ones. The lowest photogenerated electron-hole pairs recombination rate of the nanosheets was revealed by PL study. The midgap states and the expansion of $\pi$-electron conjugated system by $P$ atom introduction in $g-C_{3} N_{4}$ was suggested due to the red shift of emission peaks about $70 \mathrm{~nm}$ compared to pristine g- $\mathrm{C}_{3} \mathrm{~N}_{4}$. The more effective photoinduced carrier separation was confirmed by the fluorescence decay study and the quantitative confirmation of PL quenching was obtained. The P-g- $\mathrm{C}_{3} \mathrm{~N}_{4}$ nanosheets demonstrated significant enhancement of visible-light absorption in the region of 450-750 $\mathrm{nm}$. The nanosheets demonstrated a distinct Urbach tail absorption band, which the authors attributed to the $\mathrm{n} \rightarrow \pi^{*}$ electron transition from lone electron pairs of edge nitrogen atoms in the heptazine parts due to the formation of incompletely symmetric planar modes. The transition energy was estimated at $1.91 \mathrm{eV}$ based on the Urbach tail absorption, which is associated with midgap states. The calculated band gaps of undoped and P-g- $\mathrm{C}_{3} \mathrm{~N}_{4}$ was 2.73 and $2.56 \mathrm{eV}$, respectively. It was shown that the P-doping changed the original band gap structure due to the formation of impurity level between VB and CB. Decrease in the VB position from 1.7 to $1.57 \mathrm{eV}$ was suggested as a result of defects generation under the thermal exfoliation. The greatly improved photocatalytic $\mathrm{H}_{2}$ evolution was reached using the with $\mathrm{P}-\mathrm{g}-\mathrm{C}_{3} \mathrm{~N}_{4}$ nanosheets.

The nano-structuring and P-doping strategy was implemented by Zhao et al. via a one-pot process for improvement of the $\mathrm{g}-\mathrm{C}_{3} \mathrm{~N}_{4}$ photocatalytic hydrogen evolution activity under visible light [121]. The aqueous solution of dicyandiamide, $\mathrm{NH}_{4} \mathrm{Cl}$ (gas-template), and $\left(\mathrm{NH}_{4}\right)_{2} \mathrm{HPO}_{4}$ (P dopant) was freeze-dried and the obtained material was calcined at $550{ }^{\circ} \mathrm{C}$ over $4 \mathrm{~h}$. The SSA of P-g- $\mathrm{C}_{3} \mathrm{~N}_{4}$ was determined to be $36.4 \mathrm{~m}^{2} \cdot \mathrm{g}^{-1}$, which is higher than $5.5 \mathrm{~m}^{2} \cdot \mathrm{g}^{-1}$ of pristine $\mathrm{g}-\mathrm{C}_{3} \mathrm{~N}_{4}$. The authors confirmed that the successful nano-structuring of $\mathrm{g}-\mathrm{C}_{3} \mathrm{~N}_{4}$ was due to the gas-template application. The XPS analysis evidenced the successful doping of $P$ element in $g-C_{3} \mathrm{~N}_{4}$ and the probable replacement of $C$ with P forming P-N bonds. P-g- $\mathrm{C}_{3} \mathrm{~N}_{4}$ contained $2.05 \mathrm{wt}$. $\%$ of $\mathrm{P}$, which was determined by XPS.

In contradiction to the previous study, Su et al. [118] found the incorporation of $P$ caused the blue shift of intrinsic absorption edge of g- $\mathrm{C}_{3} \mathrm{~N}_{4}$ from $458 \mathrm{~nm}$ to $440 \mathrm{~nm}$. Accordingly, the band gap was changed from $2.74 \mathrm{eV}$ to $2.90 \mathrm{eV}$. The band gap enlargement was explained by the quantum size effect. The PL study revealed that the recombination of photo-induced charge carriers in $g-C_{3} \mathrm{~N}_{4}$ was efficiently diminished due to the P-doping and the nano-structure formation. The photocurrent density test was applied to confirm the efficiency of charge separation and migration in $\mathrm{P}-\mathrm{g}-\mathrm{C}_{3} \mathrm{~N}_{4}$. The photocurrent density of P-g- $\mathrm{C}_{3} \mathrm{~N}_{4}$ was $0.51 \mu \mathrm{mol} \cdot \mathrm{g}^{-1} \cdot \mathrm{h}^{-1} \cdot \mu \mathrm{A}^{-1}$ compared to $0.06 \mu \mathrm{mol} \cdot \mathrm{g}^{-1} \cdot \mathrm{h}^{-1} \cdot \mu \mathrm{A}^{-1}$ of pristine g- $\mathrm{C}_{3} \mathrm{~N} 4$.

P-doped tubular g- $\mathrm{C}_{3} \mathrm{~N}_{4}$ (PT-g- $\mathrm{C}_{3} \mathrm{~N}_{4}$ ) with surface defects was obtained by Guo et al. through a phosphorus-contained compounds-assisted hydrothermal method [125]. The melamine was used as a raw material. Sodium pyrophosphate, ammonium phosphate, sodium hypophosphite, and sodium phosphite were used as P-containing compounds. A hexagonal tube-shaped nanostructure of PT-g- $\mathrm{C}_{3} \mathrm{~N}_{4}$ demonstrated the increasing of SSA from 8.6 to $24.5-32.4 \mathrm{~m}^{2} \cdot \mathrm{g}^{-1}$ of pristine $\mathrm{g}^{-} \mathrm{C}_{3} \mathrm{~N}_{4}$ and PT-g- $\mathrm{C}_{3} \mathrm{~N}_{4}$ 
from various $P$ sources, respectively. According to the XPS analysis, the replacement of $C$ in the triazine moieties with $\mathrm{P}$ to form P-N bonds during synthesis was suggested. The content of P in PT-g- $\mathrm{C}_{3} \mathrm{~N}_{4}$ varied from 0.32 to $0.87 \mathrm{wt} . \%$. The highest $\mathrm{P}$ ratio was reached using sodium pyrophosphate. The XPS study also revealed decreasing of the $\mathrm{C} / \mathrm{N}$ surface atom ratio from $0.74\left(\mathrm{PT}-\mathrm{g}-\mathrm{C}_{3} \mathrm{~N}_{4}\right)$ to $0.69\left(\mathrm{~g}-\mathrm{C}_{3} \mathrm{~N}_{4}\right)$ due to carbon defects formation during the synthesis. It was also established that carbon defects exist only on the surface of $\mathrm{g}-\mathrm{C}_{3} \mathrm{~N}_{4}$ as the $\mathrm{C} / \mathrm{N}$ mass ratio determined for pristine and PT-g- $\mathrm{C}_{3} \mathrm{~N}_{4}$ samples demonstrated the same value of 0.68 . The P-doping and the tube structure expanded the visible-light absorption due to numerous reflections of light within the PT-g- $\mathrm{C}_{3} \mathrm{~N}_{4}$ tubes. The band gap of PT-g- $\mathrm{C}_{3} \mathrm{~N}_{4}$ obtained from ammonium phosphate was calculated at $2.63 \mathrm{eV}$ compared to $2.75 \mathrm{eV}$ of $\mathrm{g}-\mathrm{C}_{3} \mathrm{~N}_{4}$. The PL and photocurrent measurements confirmed the decrease of photo-induced electrons and holes recombination rate. A low resistance for interfacial charge transfer from the $g-C_{3} N_{4}$ photocatalysts to reacting molecules was observed for the PT-g- $\mathrm{C}_{3} \mathrm{~N}_{4}$ samples using electrochemical impedance spectroscopy (EIS).

Zhou et al. reported on the synthesis of $\mathrm{P}-\mathrm{g}-\mathrm{C}_{3} \mathrm{~N}_{4}$ by the thermal copolymerization of hexachlorocyclotriphosphazene and guanidinium hydrochloride, a non-expensive and environmentally friendly compound [126]. The obtained P-doped photocatalysts showed the high photocatalytic performance both in the $\mathrm{H}_{2}$ evolution and the photodecomposition of organic dyes. The synthesized P-g- $\mathrm{C}_{3} \mathrm{~N}_{4}$ demonstrated the increased SSA of $40.5 \mathrm{~m}^{2} \cdot \mathrm{g}^{-1}$ compared to $26.86 \mathrm{~m}^{2} \cdot \mathrm{g}^{-1}$ of pristine $\mathrm{g}-\mathrm{C}_{3} \mathrm{~N}_{4}$. The optical properties study revealed that the $\mathrm{P}-\mathrm{g}-\mathrm{C}_{3} \mathrm{~N}_{4}$ possessed a little bit wider band gap $(2.71 \mathrm{eV})$ compared to $2.69 \mathrm{eV}$ of $\mathrm{g}-\mathrm{C}_{3} \mathrm{~N}_{4}$. The $\mathrm{VB}$ maximum for pristine and P-doped g- $\mathrm{C}_{3} \mathrm{~N}_{4}$ were found to be $2.07 \mathrm{eV}$, and $2.12 \mathrm{eV}$, respectively. The $\mathrm{C} / \mathrm{N}$ molar ratio determined with $\mathrm{EA}$ was 0.79 and 0.85 for P-doped and pristine g- $\mathrm{C}_{3} \mathrm{~N}_{4}$ that corresponded to non-perfect framework structures of both products. From the XPS analysis of C, N and P spectra the incorporation of P-atoms by the replacement of $\mathrm{C}$-ones was concluded. XPS and ${ }^{31} \mathrm{P}$ NMR data revealed the $\mathrm{P}$ atoms location at corner-carbon and bay-carbon sites of $g-C_{3} N_{4}$. The authors suggested the formation of electron-rich state of $P-g-C_{3} N_{4}$, which was confirmed by the measurement of zeta potentials of aqueous sample suspensions. After the P-doping, the charge of surface was changed from $+7.3 \mathrm{mV}$ (for $\mathrm{g}-\mathrm{C}_{3} \mathrm{~N}_{4}$ ) to $-33.5 \mathrm{mV}$. The negatively charged surface of P-g- $\mathrm{C}_{3} \mathrm{~N}_{4}$ promoted the adsorption of the cationic dye RhB. The authors suggested the formation of Lewis acid sites ( $\mathrm{P}^{+}$centers) and intrinsic Lewis base sites (amine or imine groups) (Figure 8) in $\mathrm{g}-\mathrm{C}_{3} \mathrm{~N}_{4}$ should promote the rapid separation of photogenerated electrons and holes and, thus, favoring the photocatalytic activity of $\mathrm{H}_{2}$ evolution and $\mathrm{RhB}$ degradation.

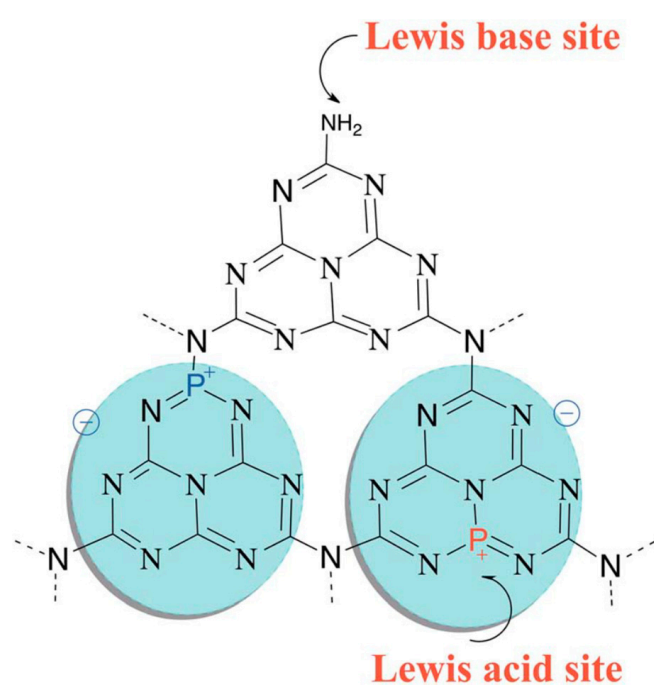

Figure 8. Scheme of a possible existing form of $\mathrm{P}$ atoms in the framework of of $\mathrm{g}-\mathrm{C}_{3} \mathrm{~N}_{4}$ and its effect on the electronic and chemical properties of $\mathrm{g}-\mathrm{C}_{3} \mathrm{~N}_{4}$. The dark blue $\mathrm{P}$ atom refers to the corner site and the red one is the bay site. Reproduced from [126] Copyright (2015), with permission from The Royal Society of Chemistry. 
Table 5. Synthetic methods, applications, and photocatalytic efficiency of P-doped g- $\mathrm{C}_{3} \mathrm{~N}_{4}$.

\begin{tabular}{|c|c|c|c|c|c|c|}
\hline Precursor & Synthetic Method & $\begin{array}{l}\text { C/Doping Element } \\
\text { Atomic Ratio, } \\
\text { Doped (Pristine) }\end{array}$ & $\begin{array}{l}\text { Photocatalytic } \\
\text { Process }\end{array}$ & Conditions of the Process & $\begin{array}{c}\text { Efficiency } \\
\text { Doped/Pristine }\end{array}$ & References \\
\hline $\begin{array}{l}\mathrm{g}-\mathrm{C}_{3} \mathrm{~N}_{4} \\
\text { P powder }\end{array}$ & Thermal modification & $\begin{array}{c}\text { P } 2 p \text { signal at around } \\
133.7 \mathrm{eV}\end{array}$ & $\mathrm{H}_{2}$ evolution & $\begin{array}{c}300 \mathrm{~W} \text { Xe lamp }(\lambda>300 \mathrm{~nm}), \\
\text { filter } \lambda>420 \mathrm{~nm}, 10 \% \mathrm{vol} \% \\
\text { TEOA, Pt co-catalyst ( } 3 \mathrm{wt} \%)\end{array}$ & $\begin{array}{c}\lambda>300 \mathrm{~nm} \\
261.2 \mu \mathrm{mol} \cdot \mathrm{g}^{-1} \cdot \mathrm{h}^{-1} / \\
81.6 \mu \mathrm{mol} \cdot \mathrm{g}^{-1} \cdot \mathrm{h}^{-1} \\
\lambda>420 \mathrm{~nm} \\
171.6 \mu \mathrm{mol} \cdot \mathrm{g}^{-1} \cdot \mathrm{h}^{-1} / \\
81.6 \mu \mathrm{mol} \cdot \mathrm{g}^{-1} \cdot \mathrm{h}^{-1}\end{array}$ & [109] \\
\hline $\begin{array}{l}\text { Urea, } \\
\text { phosphonitrilic } \\
\text { chloride }\end{array}$ & Thermal condensation & $\begin{array}{l}4.4 \text { atomic } \% \text { by EDS } \\
5.72 \text { atomic } \% \text { by XPS }\end{array}$ & $\mathrm{H}_{2} \mathrm{O}_{2}$ generation & $\begin{array}{l}\text { Visible light irradiation (420 nm } \\
\leq \lambda \leq 700 \mathrm{~nm})\end{array}$ & $\begin{array}{c}1968 \mu \mathrm{mol} \cdot \mathrm{g}^{-1} \cdot \mathrm{h}^{-1} / \\
68 \mu \mathrm{mol} \cdot \mathrm{g}^{-1} \cdot \mathrm{h}^{-1}\end{array}$ & [108] \\
\hline $\mathrm{NH}_{4} \mathrm{SCN}, \mathrm{NH}_{4} \mathrm{PF}_{6}$ & Thermal condensation & - & $\mathrm{RhB}$ destruction & $300 \mathrm{~W}$ Xe lamp, filter $\lambda>420 \mathrm{~nm}$ & $\begin{array}{l}0.09856 \mathrm{~min}^{-1} / \\
0.03679 \mathrm{~min}^{-1}\end{array}$ & [110] \\
\hline $\begin{array}{c}\mathrm{g}-\mathrm{C}_{3} \mathrm{~N}_{4} \\
\text { phosphorene }\end{array}$ & Mechanically mixing & 1.8 wt. $\%$ & $\mathrm{H}_{2}$ evolution & $\begin{array}{c}300 \mathrm{~W} \text { Xe lamp, filter } \lambda>400 \mathrm{~nm}, \\
\text { lactic acid ( } 88 \mathrm{vol} \%)\end{array}$ & $\begin{array}{l}571 \mu \mathrm{mol} \cdot \mathrm{g}^{-1} \cdot \mathrm{h}^{-1} / \\
43 \mu \mathrm{mol} \cdot \mathrm{g}^{-1} \cdot \mathrm{h}^{-1}\end{array}$ & [117] \\
\hline $\begin{array}{l}\text { g- } \mathrm{C}_{3} \mathrm{~N}_{4} \text {, sodium } \\
\text { hypophosphite }\end{array}$ & $\begin{array}{l}\text { Thermal treatment } \\
\text { method }\end{array}$ & 13.52 wt. $\%$ & RhB destruction & $\begin{array}{l}300 \mathrm{~W} \text { Xe lamp, } \\
\lambda: 420-780 \mathrm{~nm}\end{array}$ & $\begin{array}{c}0.0525 \mathrm{~min}^{-1} / \\
0.0126 \mathrm{~min}^{-1}\end{array}$ & [115] \\
\hline $\begin{array}{l}\text { Urea, adenosine } \\
\text { phosphate }\end{array}$ & $\begin{array}{l}\text { Thermal condensation } \\
\text { followed by thermal } \\
\text { exfoliation method }\end{array}$ & 2.17 atomic $\%$ & $\mathrm{H}_{2}$ evolution & $\begin{array}{c}300 \mathrm{~W} \text { Xe lamp, filters } \\
\lambda: \text { 400, } 420,435,450,550 \mathrm{~nm} ; \\
10 \% \text { vol } \% \text { TEOA, Pt co-catalyst } \\
(3 \mathrm{wt} . \%)\end{array}$ & $\begin{array}{l}9523.7 \mu \mathrm{mol} \cdot \mathrm{g}^{-1} \cdot \mathrm{h}^{-1} / \\
\quad 458 \mu \mathrm{mol} \cdot \mathrm{g}^{-1} \cdot \mathrm{h}^{-1}\end{array}$ & [118] \\
\hline Urea, $\mathrm{NH}_{4} \mathrm{H}_{2} \mathrm{PO}_{2}$ & Thermal condensation & - & $\mathrm{H}_{2}$ evolution & $\begin{array}{c}300 \mathrm{~W} \text { Xe lamp, filter } \\
\lambda 400 \mathrm{~nm}, 20 \% \text { vol } \% \text { TEOA, } \\
\text { Pt co-catalyst ( } 1 \text { wt. } \%)\end{array}$ & $\begin{array}{l}5.7 \text { times that of } \\
\text { pristine }\end{array}$ & [119] \\
\hline $\begin{array}{l}\text { Dicyandiamide, } \\
\mathrm{NH}_{4} \mathrm{Cl} \\
\left(\mathrm{NH}_{4}\right)_{2} \mathrm{HPO}_{4}\end{array}$ & Thermal condensation & $1.53 \mathrm{wt} \%$ by EDS & $\mathrm{H}_{2}$ evolution & $\begin{array}{c}300 \mathrm{~W} \text { Xe lamp, filter } \\
\lambda 420 \mathrm{~nm}, 10 \% \text { vol } \% \text { TEOA, } \\
\text { Pt co-catalyst ( } 3 \text { wt. } \% \text { ) }\end{array}$ & $\begin{array}{l}33.2 \mu \mathrm{mol} \cdot \mathrm{g}^{-1} \cdot \mathrm{h}^{-1} / \\
10.7 \mu \mathrm{mol} \cdot \mathrm{g}^{-1} \cdot \mathrm{h}^{-1}\end{array}$ & [126] \\
\hline
\end{tabular}




\section{Vacancy-Doped g- $\mathrm{C}_{3} \mathrm{~N}_{4}$}

The alternative way to modulate the $\mathrm{g}-\mathrm{C}_{3} \mathrm{~N}_{4}$ electronic band structure to favor visible light harvesting, accelerate charge separation, and transport was reported to be homogeneous self-modification with nitrogen [127-138] or carbon [88,139-141] vacancies. Native point defect doping via thermal treatment is an easy and promising method to tune the electrical transport properties of semiconductors made for renewable-energy conversion. By introducing additional energy levels and acting as reactive sites, vacancies can play a significant role in medication of the properties of photocatalysts (Table 6). The most common strategies of synthesis of nitrogen or carbon defective g- $\mathrm{C}_{3} \mathrm{~N}_{4}$ are the post-heat treatment in $\mathrm{H}_{2}$ or $\mathrm{Ar}[127,141]$, the polymerization in various atmospheres $[88,128,129]$, the post-heat treatment with a reducing agent $[88,130,131]$, the thermal copolymerization with agents that deliberates gas $[132,133,138]$, and the quick post-thermal treatment $[135,136,139,142]$.

Wang et al. created $\mathrm{N}$ vacancies in $\mathrm{g}-\mathrm{C}_{3} \mathrm{~N}_{4}$ by the copolymerization of urea with oxalyl dihydrazide $(\mathrm{ODH})$ as an environmental atmosphere control agent [133]. The thermal destruction of ODH caused the $\mathrm{H}_{2}$ liberation and produced a certain amount of heat that resulted in the defects formation in $\mathrm{g}^{-} \mathrm{C}_{3} \mathrm{~N}_{4}$. The source of $\mathrm{H}_{2}$ was $\mathrm{N}_{2} \mathrm{H}_{4}$ as a product of the pyrolysis of $\mathrm{ODH}$ and $\mathrm{NH}_{3}\left(\mathrm{NH}_{3}\right.$ was produced by the thermal condensation of urea) at $135-140{ }^{\circ} \mathrm{C}$. The SSA of pristine and modulated with $\mathrm{N}$ vacancies $\mathrm{g}-\mathrm{C}_{3} \mathrm{~N}_{4}\left(\mathrm{~V}-\mathrm{g}-\mathrm{C}_{3} \mathrm{~N}_{4}\right)$ were 85.4 and $116.9 \mathrm{~m}^{2} \cdot \mathrm{g}^{-1}$, respectively. The progressive increasing of the $\mathrm{C} / \mathrm{N}$ atomic ratio was observed. The atomic ratio of $\mathrm{C} / \mathrm{N}$ determined with EA 0.65 for pristine and 0.74 for $\mathrm{V}-\mathrm{g}-\mathrm{C}_{3} \mathrm{~N}_{4}$ was in agreement with the data from EDS and XPS (Table 4). The formation of C-C bond was confirmed using ${ }^{13} \mathrm{C}$ solid-state magic-angle spinning nuclear magnetic resonance (MAS NMR) (Figure 9a) by the appearance of a small peak at $169.5 \mathrm{ppm}$ in $\mathrm{g}-\mathrm{C}_{3} \mathrm{~N}_{4}$ modulated with $\mathrm{N}$ vacancies that was ascribed to $\mathrm{C}_{2 \mathrm{~N}-\mathrm{C}}$ (3). The enhanced ESR signal at $\mathrm{g}=1.9997$ (Figure $9 \mathrm{~b}$ ) illustrated the presence of unpaired electrons on the $\mathrm{C}$ atoms, which appeared due to the loss of $\mathrm{N}$ atoms (Figure $9 \mathrm{c}$ ).
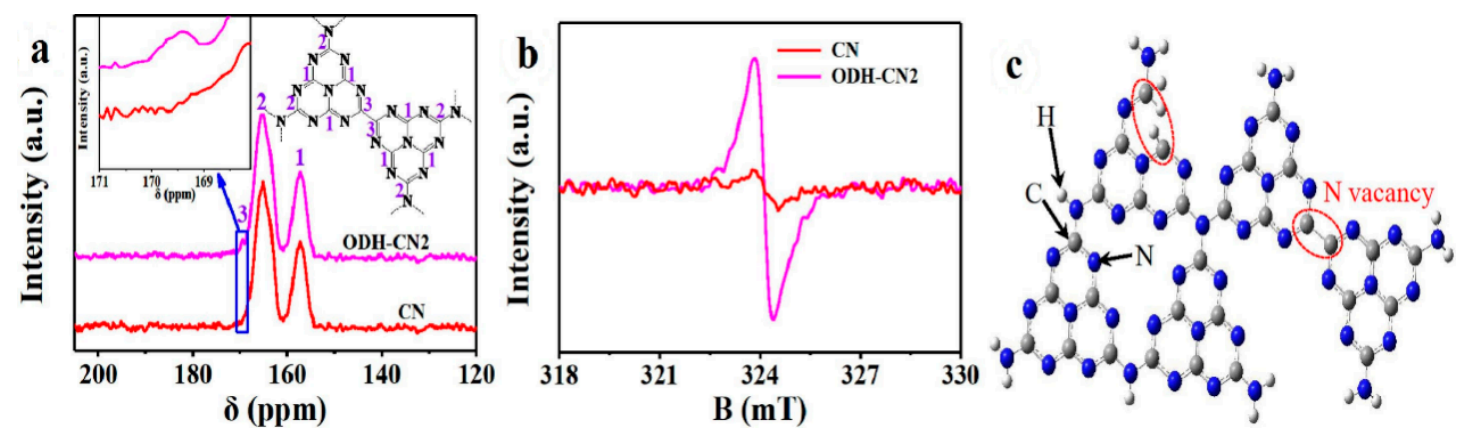

Figure 9. ${ }^{13} \mathrm{C}$ solid-state magic-angle spinning NMR spectra (a), electron paramagnetic resonance (EPR) spectra of $\mathrm{g}-\mathrm{C}_{3} \mathrm{~N}_{4}(\mathrm{CN})$ and oxalyl dihydrazide $(\mathrm{ODH})-\mathrm{CN} 2(\mathbf{b})$, structure model of ODH-CN with $\mathrm{N}$ vacancies (c). Reprinted from [133] Copyright (2020), with permission from Elsevier.

Introduction of $\mathrm{N}$ vacancies resulted in increasing of the crystallinity of g- $\mathrm{C}_{3} \mathrm{~N}_{4}$ as was detected by the XRD study. The authors also observed that the absorption band of the $\mathrm{N}$ vacancies doped $\mathrm{g}-\mathrm{C}_{3} \mathrm{~N}_{4}$ was red shifted compared with pristine $\mathrm{g}-\mathrm{C}_{3} \mathrm{~N}_{4}$, resulting in the bandgap narrowing from $2.75 \mathrm{eV}$ to $2.61 \mathrm{eV}$. The PL, photocurrent, and EIS studies demonstrated that the interface charge transport can be effectively enhanced by the introduction of $\mathrm{N}$ vacancies. 
The introduction of intra- and inter-triazine $\mathrm{N}$-vacancies into g- $\mathrm{C}_{3} \mathrm{~N}_{4}$ was performed under melamine treatment in various atmospheres by Li et al. [128]. The theoretical DFT calculation and experimental results allowed these authors to determine the type of $\mathrm{N}$-vacancies obtained under various conditions. The inter-triazine $\mathrm{N}$-vacancies were introduced after treating melamine in the $\mathrm{CCl}_{4}$ atmosphere. The polymerization of melamine in $\mathrm{Ar}$ and $\mathrm{H}_{2}$ resulted in the formation of "vacancy-free" and intra-triazine N-vacancies contained g- $\mathrm{C}_{3} \mathrm{~N}_{4}$, respectively. The DFT calculation and optical properties study demonstrated that the bandgap was only slightly reduced by the intra-triazine $\mathrm{N}$-vacancy but was strongly reduced by the inter-triazine $\mathrm{N}$-vacancy. The band gap values of $\mathrm{g}-\mathrm{C}_{3} \mathrm{~N}_{4}$ obtained in $\mathrm{CCl}_{4}, \mathrm{Ar}$, and $\mathrm{H}_{2}$ were determined to be $2.76,2.79$, and $2.80 \mathrm{eV}$, respectively. The minor changes in the values of SSA were observed for all samples: $11.2,12.6$, and $16.0 \mathrm{~m}^{2} \cdot \mathrm{g}^{-1}$ for $\mathrm{g}-\mathrm{C}_{3} \mathrm{~N}_{4}$ treated at $\mathrm{CCl}_{4}, \mathrm{Ar}$, and $\mathrm{H}_{2}$, respectively. Compared with "vacancy-free" g- $\mathrm{C}_{3} \mathrm{~N}_{4}$, the EPR signals of g- $\mathrm{C}_{3} \mathrm{~N}_{4}$ with inter- and intra-triazine $\mathrm{N}$-vacancies were much enhanced, indicating the existence of more unpaired electrons. The efficient separation of photogenerated carriers was confirmed by the PL quenching and photocurrent enhancement of both types of nitrogen $\mathrm{V}-\mathrm{g}-\mathrm{C}_{3} \mathrm{~N}_{4}$ due to the extra channel of electron transfer.

Xie et al. designed g- $\mathrm{C}_{3} \mathrm{~N}_{4}$ with two types of regulatable nitrogen vacancies in a one pot method by the $\mathrm{KOH}$-assisted calcination treatment of pristine g- $\mathrm{C}_{3} \mathrm{~N}_{4}$ for a remarkably high $\mathrm{H}_{2} \mathrm{O}_{2}$ evolution photoactivity [131]. During the thermal treatment, the formation of $\mathrm{N}_{2} \mathrm{C}$ and $\mathrm{NH}_{\mathrm{x}}$ vacancies occurred due to changing molecular structure influenced by $\mathrm{KOH}$. The loss of $\mathrm{g}-\mathrm{C}_{3} \mathrm{~N}_{4}$ ordered structure was caused by the treatment as well. The experimental analyses and theoretic DFT calculations revealed that the $\mathrm{N}_{2} \mathrm{C}$ vacancies improved the photoexcited charges separation and the $\mathrm{NH}_{\mathrm{x}}$ vacancy activated oxygen in two-electron process. The favorable amount of two types of $\mathrm{N}$ vacancies in $\mathrm{g}-\mathrm{C}_{3} \mathrm{~N}_{4}$ was determined. The $\mathrm{N} / \mathrm{C}$ atomic ratios for a sample with an optimal amount of both types of $\mathrm{N}$ vacancies decreased compared with pristine $\mathrm{g}-\mathrm{C}_{3} \mathrm{~N}_{4}$. The SSA was $71 \mathrm{~m}^{2} \mathrm{~g}^{-1}$ and the thermal post treatment of g- $\mathrm{C}_{3} \mathrm{~N}_{4}$ with and without $\mathrm{KOH}$ decreased from 48 to $45 \mathrm{~m}^{2} \mathrm{~g}^{-1}$, respectively. Due to the efficient carrier separation and oxygen activation processes, the nitrogen defective g- $\mathrm{C}_{3} \mathrm{~N}_{4}$ demonstrated a 15-fold enhancement of $\mathrm{H}_{2} \mathrm{O}_{2}$ evolution $\left(152.6 \mu \mathrm{mol} \cdot \mathrm{h}^{-1}\right)$ and superior stability over $52 \mathrm{~h}$.

The carbon vacancies were prepared in the $\mathrm{g}-\mathrm{C}_{3} \mathrm{~N}_{4}$ framework via magnesium vapor etching by $\mathrm{Li}$ et al. [88]. They calcined a mixture of pristine $\mathrm{g}-\mathrm{C}_{3} \mathrm{~N}_{4}$ and magnesium powders to get magnesium vapor that etched the $\mathrm{N}-(\mathrm{C})_{3}, \mathrm{C}-\mathrm{N}=\mathrm{C}$, or $\mathrm{C}=\mathrm{C}$ lattice sites resulting in the vacancies. The applied method allowed the authors to increase the SSA from $58.5 \mathrm{~m}^{2} \mathrm{~g}^{-1}$ of g- $\mathrm{C}_{3} \mathrm{~N}_{4}$ to $70.6 \mathrm{~m}^{2} \mathrm{~g}^{-1}$ of V-g- $\mathrm{C}_{3} \mathrm{~N}_{4}$ that can supply more active centers for photocatalytic process. The decreased $\mathrm{C} / \mathrm{N}$ atomic ratio from 0.78 of $\mathrm{g}-\mathrm{C}_{3} \mathrm{~N}_{4}$ to 0.51 of $\mathrm{V}-\mathrm{g}-\mathrm{C}_{3} \mathrm{~N}_{4}$ was determined by the EDS analysis. The further evidence of carbon vacancies in $\mathrm{g}-\mathrm{C}_{3} \mathrm{~N}_{4}$ framework after etching was confirmed by the XPS analysis. The smaller $\mathrm{C} / \mathrm{N}$ atomic ratio of $\mathrm{V}-\mathrm{g}-\mathrm{C}_{3} \mathrm{~N}_{4}$ and the disappearance of the deconvoluted peak of C-C group in the high-resolution $\mathrm{C}$ 1s spectrum of $\mathrm{V}-\mathrm{g}-\mathrm{C}_{3} \mathrm{~N}_{4}$ evidenced the origin of $\mathrm{C}$ vacancies from the destruction of $\mathrm{C}-\mathrm{C}$ groups. A slight blue-shift of the absorption threshold and the absorption intensity enhancement from $450 \mathrm{~nm}$ to $800 \mathrm{~nm}$ was observed by DRS of $\mathrm{V}-\mathrm{g}-\mathrm{C}_{3} \mathrm{~N}_{4}$. The calculated band-gap values were $2.87 \mathrm{eV}$ and $2.98 \mathrm{eV}$ for pristine and $\mathrm{C}$ vacancies-doped $\mathrm{g}-\mathrm{C}_{3} \mathrm{~N}_{4}$. The significant decrease of the V-g- $\mathrm{C}_{3} \mathrm{~N}_{4}$ PL compared to pristine g- $\mathrm{C}_{3} \mathrm{~N}_{4}$ confirmed its ability to inhibit charge recombination due to the capture of electrons by $\mathrm{C}$ vacancies. $\mathrm{V}-\mathrm{g}-\mathrm{C}_{3} \mathrm{~N}_{4}$ also demonstrated the higher charge separation efficiency. The transient photocurrent responses under irradiation in an on-and-off cycle mode of carbon V-g- $\mathrm{C}_{3} \mathrm{~N}_{4}$ was larger than that of pristine g- $\mathrm{C}_{3} \mathrm{~N}_{4}$. As a result, V-g- $\mathrm{C}_{3} \mathrm{~N}_{4}$ demonstrated the significant improvement of photocatalytic $\mathrm{H}_{2}$ generation performance. 
Table 6. Synthetic methods, applications, and photocatalytic efficiency of vacancy-doped g- $\mathrm{C}_{3} \mathrm{~N}_{4}$.

\begin{tabular}{|c|c|c|c|c|c|c|}
\hline Precursor & Synthetic Method & $\begin{array}{c}\text { C/N Element Atomic } \\
\text { Ratio, } \\
\text { Doped (Pristine) } \\
\end{array}$ & $\begin{array}{l}\text { Photocatalytic } \\
\text { Process }\end{array}$ & Conditions of the Process & $\begin{array}{c}\text { Efficiency } \\
\text { Doped/Pristine }\end{array}$ & References \\
\hline $\begin{array}{l}\text { Urea, } \\
\text { oxalyl dihydrazide } \\
(\mathrm{ODH})\end{array}$ & $\begin{array}{c}\text { Thermal } \\
\text { copolymerization }\end{array}$ & $\begin{array}{c}0.74 \text { (0.65) by element } \\
\text { analysis; } \\
0.67(0.61) \text { by XPS } \\
1.87(1.09) \text { by EDX }\end{array}$ & $\begin{array}{c}\text { Tetracycline } \\
\text { hydrochloride } \\
\text { (TC-HCl) and } \\
\text { sulfamethoxazole } \\
\text { (SMZ) destruction; } \\
\mathrm{H}_{2} \text { evolution }\end{array}$ & $\begin{array}{c}300 \mathrm{~W} \text { Xe lamp, } \\
\text { filter } \lambda>420 \mathrm{~nm}, \\
\text { Pt co-catalyst }(1 \mathrm{wt} . \%), \text { TEOA }\end{array}$ & $\begin{array}{c}\text { SMZ destruction: } \\
0.0203 \mathrm{~min}^{-1} / \\
0.0066 \mathrm{~min}^{-1} ; \\
\mathrm{H}_{2} \text { evolution: } \\
5833.1 \mu \mathrm{mol} \cdot \mathrm{h}^{-1} \cdot \mathrm{g}^{-1} / \\
1458.2 \mu \mathrm{mol} \cdot \mathrm{g}^{-1}\end{array}$ & [133] \\
\hline Urea, dicyandiamide & $\begin{array}{c}\text { Post-thermal } \\
\text { treatment of } \\
\mathrm{g}-\mathrm{C}_{3} \mathrm{~N}_{4}\end{array}$ & - & $\mathrm{H}_{2}$ evolution & Visible light irradiation & $\begin{array}{l}6.5 \mu \mathrm{mol} \cdot \mathrm{g}^{-1} / \\
2.1 \mu \mathrm{mol} \cdot \mathrm{g}^{-1}\end{array}$ & [137] \\
\hline Melamine & $\begin{array}{l}\text { Polymerization in } \\
\text { atmosphere of: } \mathrm{CCl}_{4} ; \\
\mathrm{H}_{2} ; \mathrm{Ar}\end{array}$ & $\begin{array}{c}0.61(0.65) \text { by } \\
\text { elemental analysis }\end{array}$ & $\mathrm{H}_{2}$ evolution & $\begin{array}{c}\text { 300W Xe lamp, filter } \lambda>420 \mathrm{~nm}) \\
\operatorname{Pt}(3 \%), \text { TEOA }(10 \mathrm{vol} \%)\end{array}$ & $\begin{array}{l}0.079 \mathrm{~min}^{-1} / \\
0.0032 \mathrm{~min}^{-1}\end{array}$ & [128] \\
\hline Urea & $\begin{array}{c}\mathrm{KOH} \text {-assisted } \\
\text { calcination treatment }\end{array}$ & $\begin{array}{l}1.45(1.51) \text { by organic } \\
\text { elemental analysis } \\
1.32(1.64) \text { by XPS }\end{array}$ & $\mathrm{H}_{2} \mathrm{O}_{2}$ production & $\begin{array}{l}\text { simulated sunlight lamp } \\
20 \text { vol\% ethanol }\end{array}$ & $\begin{array}{c}152.6 \mu \mathrm{mol} \cdot \mathrm{h}^{-1} / \\
10.2 \mu \mathrm{mol} \cdot \mathrm{h}^{-1}\end{array}$ & [131] \\
\hline $\begin{array}{c}\text { Dicyandiamide, } \\
\mathrm{NH}_{4} \mathrm{Cl} \\
\text { 3-amino-1,2,4-triazol }\end{array}$ & $\begin{array}{l}\text { Thermal } \\
\text { polymerization with } \\
\text { post treatment in } \mathrm{N}_{2}\end{array}$ & $\begin{array}{l}1.260(1.489) \text { by } \\
\text { element analysis }\end{array}$ & $\mathrm{H}_{2}$ evolution & $\begin{array}{c}\text { 300W Xe lamp, filter } \lambda>400 \mathrm{~nm}) \\
\operatorname{Pt}(3 \%), \text { TEOA }(10 \mathrm{vol} \%)\end{array}$ & $\begin{array}{l}3882.5 \mu \mathrm{mol} \cdot \mathrm{h}^{-1} \cdot \mathrm{g}^{-1} / \\
85.0 \mu \mathrm{mol} \cdot \mathrm{h}^{-1} \cdot \mathrm{g}^{-1}\end{array}$ & [134] \\
\hline Urea, $\mathrm{Mg}$ powder & $\begin{array}{l}\text { magnesium vapor } \\
\text { etching }\end{array}$ & $\begin{array}{l}0.51(0.78) \text { by EDX } \\
0.92(1.14) \text { by XPS }\end{array}$ & $\mathrm{H}_{2}$ evolution & $\begin{array}{c}\text { 300W Xe lamp, filter } \lambda>400 \mathrm{~nm}) \\
\operatorname{Pt}(3 \%), \text { TEOA }(10 \mathrm{vol} \%)\end{array}$ & $\begin{array}{l}450 \mu \mathrm{mol} \cdot \mathrm{h}^{-1} \cdot \mathrm{g}^{-1} / \\
225 \mu \mathrm{mol} \cdot \mathrm{h}^{-1} \cdot \mathrm{g}^{-1} \\
\mathrm{NH}_{4}^{+} \text {formation: }\end{array}$ & [88] \\
\hline Dicyandiamide & two-step calcination & $0.81(0.85)$ by XPS & $\mathrm{N}_{2}$ fixation & 300W Xe lamp & $\begin{array}{l}54 \mathrm{mmol} \cdot \mathrm{L}^{-1} / \\
24 \mathrm{mmol} \cdot \mathrm{L}^{-1}\end{array}$ & [139] \\
\hline Urea, melamine & $\begin{array}{c}\text { precursor } \\
\text { preprocessing and } \\
\text { thermolysis in } \mathrm{N}_{2}\end{array}$ & - & NO oxidation & LED lamp $(\lambda \geq 448 \mathrm{~nm})$ & $\begin{array}{c}\text { the NO oxidation in } \\
30 \text { min of irradiation } \\
47.7 \% / 22 \%\end{array}$ & [140] \\
\hline
\end{tabular}


Zhang et al. prepared porous ultrathin carbon defective g- $\mathrm{C}_{3} \mathrm{~N}_{4}$ by the thermal treatment of g- $\mathrm{C}_{3} \mathrm{~N}_{4}$ in two steps [139]. The obtained V-g- $\mathrm{C}_{3} \mathrm{~N}_{4}$ possessed lower crystallinity compared to pristine g- $\mathrm{C}_{3} \mathrm{~N}_{4}$ due to the formation of vacancies in the $\mathrm{C}_{3} \mathrm{~N}_{4}$ structure. The two-step thermal treatment promoted the formation mesoporous structure with the increased SSA from $2.06 \mathrm{~m}^{2} \mathrm{~g}^{-1}$ to $162.57 \mathrm{~m}^{2}$ $\mathrm{g}^{-1}$. The formation of carbon defects was evidenced by the reduced $\mathrm{C} / \mathrm{N}$ ratio from 0.85 to 0.81 determined by XPS. The enhanced EPR signal of $\mathrm{V}-\mathrm{g}-\mathrm{C}_{3} \mathrm{~N}_{4}$ corresponded to the presence of $\mathrm{C}$ vacancies. The absorption edge of $\mathrm{V}-\mathrm{g}-\mathrm{C}_{3} \mathrm{~N}_{4}$ was blue-shifted due to thermal oxidation of pristine $\mathrm{g}-\mathrm{C}_{3} \mathrm{~N}_{4}$. The band gap values were 2.74 and $3.02 \mathrm{eV}$ for the pristine and carbon defective g- $\mathrm{C}_{3} \mathrm{~N}_{4}$, respectively. The VB potentials of pristine and thermally exfoliated carbon $\mathrm{V}-\mathrm{g}-\mathrm{C}_{3} \mathrm{~N}_{4}$ (determined by XPS) were $2.24 \mathrm{eV}$ and $2.40 \mathrm{eV}$, respectively. The conduction bands were $-0.50 \mathrm{eV}$ and $-0.62 \mathrm{eV}$, respectively. As the reduction potential of $\mathrm{N}_{2}$ to $\mathrm{NH}_{4}{ }^{+}$was more positive than the $\mathrm{CB}$ potentials of both $\mathrm{g}-\mathrm{C}_{3} \mathrm{~N}_{4}$, the authors predicted the ability to reduce nitrogen under irradiation. The PL study of pristine $\mathrm{g}-\mathrm{C}_{3} \mathrm{~N}_{4}$ and V-g- $C_{3} N_{4}$ was not in agreement with other reports on doped $g-C_{3} N_{4}[88,139]$. The authors attributed the longer lifetime of excited state of $\mathrm{V}-\mathrm{g}-\mathrm{C}_{3} \mathrm{~N}_{4}$ to the decreasing of the recombination rate of electron-hole pairs. The confirmation of efficient charge carrier separation was obtained by the strong increasing of photocurrent response intensity of carbon $\mathrm{V}-\mathrm{g}-\mathrm{C}_{3} \mathrm{~N}_{4}$ compared to g- $\mathrm{C}_{3} \mathrm{~N}_{4}$. The capacity of V-g- $\mathrm{C}_{3} \mathrm{~N}_{4}$ to transport charge carriers was suggested to be due to its porous structure as a result of carbon vacancies, which also promoted nitrogen fixation in a water environment.

\section{Photocatalytic Applications of Non-Metal Elements Doped g- $\mathrm{C}_{3} \mathrm{~N}_{4}$}

Graphitic carbon nitride as a promising photocatalyst found applications in many photocatalytic processes, such as $\mathrm{CO}_{2}$ reduction, hydrogen evolution, pollutants degradation, and so forth [124,142-147]. The variety of strategies are offered to optimize photocatalytic processes by the modulation of g- $\mathrm{C}_{3} \mathrm{~N}_{4}$-based photocatalysts composition and morphology to enlarge the range of absorbed light, promote charge carrier separation, and increase specific surface area.

\subsection{Photocatalytic $\mathrm{CO}_{2}$ Reduction}

The nanostructured graphitic carbon nitrides were suggested to be the perspective materials for $\mathrm{CO}_{2}$ capture and transformation into fine chemicals due to perfect semiconducting band gap with suitable band edges (Figure 10a-c).
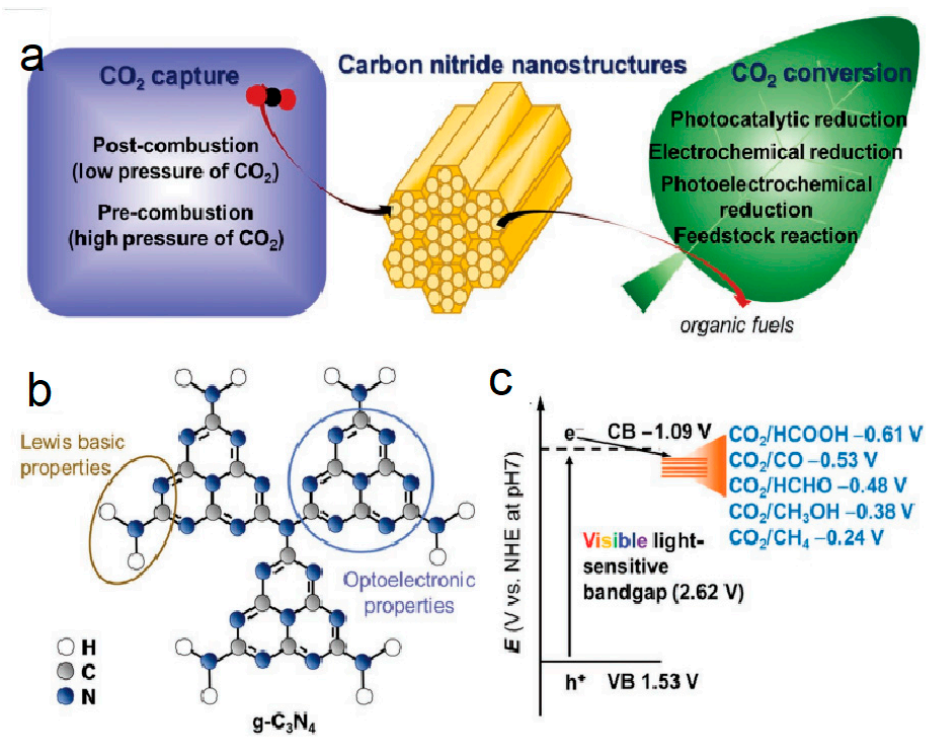

Figure 10. Schematic illustration of $\mathrm{CO}_{2}$ capture and conversion to organic fuels using carbon nitride nanostructures (a), molecular structure (b) and band structure (c) of $\mathrm{g}-\mathrm{C}_{3} \mathrm{~N}_{4}$. Reproduced with permission [145], Copyright 2019, with permission from John Wiley and Sons. 
The hierarchical O-g- $\mathrm{C}_{3} \mathrm{~N}_{4}$ nanotubes obtained by thermal polycondensation of melamine exhibited significantly improved the photocatalytic $\mathrm{CO}_{2}$ reduction performance under visible light irradiation in comparison with pristine g- $\mathrm{C}_{3} \mathrm{~N}_{4}$ [43]. Compared with pristine g- $\mathrm{C}_{3} \mathrm{~N}_{4}, \mathrm{O}-\mathrm{g}-\mathrm{C}_{3} \mathrm{~N}_{4}$ nanotubes have the following advantages: (1) Larger SSA and more photoactive sites; (2) wider visible-light absorption range and suitable band structure; (3) improved separation efficiency of charge carriers; and (4) high $\mathrm{CO}_{2}$ uptake capacity. The photocatalytic activity was evaluated by the generation rates of $\mathrm{CH}_{3} \mathrm{OH}$ as it was the main product of photocatalytic performance on both $\mathrm{g}-\mathrm{C}_{3} \mathrm{~N}_{4}$ and the nanotubes. The average $\mathrm{CH}_{3} \mathrm{OH}$ generation rate of $0.88 \mu \mathrm{mol} \cdot \mathrm{g}^{-1} \cdot \mathrm{h}^{-1}$ was about five times higher than that produced by $\mathrm{g}-\mathrm{C}_{3} \mathrm{~N}_{4}\left(0.17 \mu \mathrm{mol} \cdot \mathrm{g}^{-1} \cdot \mathrm{h}^{-1}\right)$. The $\mathrm{CH}_{3} \mathrm{OH}$ generation rate was approximately the same in three cycles $(3 \mathrm{~h})$. Thus, it was concluded that the highly active and stable O-g- $\mathrm{C}_{3} \mathrm{~N}_{4}$ nanotubes are the promising photocatalysts for hydrocarbon fuel generation by the photocatalytic $\mathrm{CO}_{2}$ reduction under visible light irradiation.

The direction for the design and synthesis of low-cost N-g- $\mathrm{C}_{3} \mathrm{~N}_{4}$ materials for the photocatalytic $\mathrm{CO}_{2}$ reduction under UV light was proposed by Mo et al. [62]. As photocatalysts they used N-g- $\mathrm{C}_{3} \mathrm{~N}_{4}$ nanotubes obtained by the heating of supramolecular intermediate under $\mathrm{NH}_{3}$, air, $\mathrm{Ar}$, and $\mathrm{N}_{2}$ atmospheres. The influence of the porous structures and surface amino groups on the photocatalytic process was investigated. The main reaction products were determined to be $\mathrm{CO}$ and a small amount of $\mathrm{H}_{2}$. The highest $\mathrm{CO}$ formation rate of $103.6 \mu \mathrm{mol} \cdot \mathrm{g}^{-1} \cdot \mathrm{h}^{-1}$ was observed for pristine g- $\mathrm{C}_{3} \mathrm{~N}_{4}\left(\mathrm{NH}_{3}\right)$ that was obtained by the precursor thermal treatment in the $\mathrm{NH}_{3}$ atmosphere. This rate was 17.0, 1.8, 2.7, and 2.8 times higher than that with $\mathrm{g}-\mathrm{C}_{3} \mathrm{~N}_{4}$ and the $\mathrm{N}-\mathrm{g}-\mathrm{C}_{3} \mathrm{~N}_{4}$ materials, which were obtained by the thermal treatment in air, Ar, and $\mathrm{N}_{2}$, respectively. The high photocatalytic activity of $\mathrm{g}^{-} \mathrm{C}_{3} \mathrm{~N}_{4}$ $\left(\mathrm{NH}_{3}\right)$ catalyst was explained by the peculiar porous nanotube structure and by the increased quantity of amino groups. The porous 1D tubular structure improved the charge separation efficiency and provided numerous active sites for the surface reaction. The modification of $g-C_{3} N_{4}$ with amino groups not only extended the lifetime of excited species, but also caused the strong Lewis basicity, which was beneficial for the $\mathrm{CO}_{2}$ adsorption with further promotion of the $\mathrm{CO}_{2}$ photoreduction. The $\mathrm{CO}$ formation rates with g- $\mathrm{C}_{3} \mathrm{~N}_{4}\left(\mathrm{NH}_{3}\right)$ photocatalyst was 15 and 13 times higher than those of $\mathrm{TiO}_{2}(\mathrm{P} 25)$ and black phosphorus, respectively. The nitrogen-doped $\mathrm{sp}^{2}$-carbon (graphitic)-rich electrodes demonstrated high selectivity for the $\mathrm{CO}_{2}$ reduction reaction products [148]. The authors evidenced that the host structure of nitrogen dopants was crucial for the catalytic activity observed.

The photocatalytic $\mathrm{CO}_{2}$ reduction of amine-functionalized g- $\mathrm{C}_{3} \mathrm{~N}_{4}$ obtained by its treatment with monoethanolamine was evaluated under UV light [58]. The amine-modified g- $\mathrm{C}_{3} \mathrm{~N}_{4}$ demonstrated the considerable enhancement in the $\mathrm{CO}_{2}$ conversion in comparison with pristine $\mathrm{g}-\mathrm{C}_{3} \mathrm{~N}_{4}$. The main products were found to be $\mathrm{CH}_{3} \mathrm{OH}$ and $\mathrm{CH}_{4}$. The pristine $\mathrm{g}-\mathrm{C}_{3} \mathrm{~N}_{4}$ was reported to have the photocatalytic $\mathrm{CH}_{3} \mathrm{OH}$-production rate of $0.26 \mu \mathrm{mol} \cdot \mathrm{h}^{-1} \cdot \mathrm{g}^{-1}$ and only trace amount of $\mathrm{CH}_{4}$, while the optimal amine-functionalized sample provided the similar $\mathrm{CH}_{3} \mathrm{OH}$ production rate of $0.28 \mu \mathrm{mol} \cdot \mathrm{h}^{-1} \cdot \mathrm{g}^{-1}$ and, further, the $\mathrm{CH}_{4}$-production rate of $0.34 \mu \mathrm{mol} \cdot \mathrm{h}^{-1} \cdot \mathrm{g}^{-1}$. Similar to Mo et al. [62], the high activity of the amine-functionalized photocatalyst was attributed to the enhancement of $\mathrm{CO}_{2}$ adsorption and destabilization ability of $\mathrm{g}_{-} \mathrm{C}_{3} \mathrm{~N}_{4}$ after the amine-functionalization treatment. The authors assumed that $\mathrm{CO}_{2}$ was adsorbed on the surface of amine-functionalized g- $\mathrm{C}_{3} \mathrm{~N}_{4}$ through acid-base interactivity with amino groups and formed $\mathrm{HCO}_{3}{ }^{-}$. As $\mathrm{HCO}_{3}{ }^{-}$was more active than linear $\mathrm{CO}_{2}$ it promoted the formation of $\mathrm{CH}_{4}$ [149]. It was shown that under the same conditions, $\mathrm{CO}_{2}$ molecules formed $\mathrm{CH}_{3} \mathrm{OH}$ [98]. Similar to Mo et al. [62], it was established that the exorbitant surface amine functionalization caused the decrease of photocatalytic activity due to reducing surface-active sites.

S-g- $\mathrm{C}_{3} \mathrm{~N}_{4}$ fabricated by the thermal polycondensation of thiourea demonstrated enhanced activity in the photocatalytic reduction of $\mathrm{CO}_{2}$ into hydrocarbon fuels under UV-Vis light irradiation in comparison with pristine g- $\mathrm{C}_{3} \mathrm{~N}_{4}$ [98]. The main product of photocatalytic $\mathrm{CO}_{2}$ reduction was $\mathrm{CH}_{3} \mathrm{OH}$. The $\mathrm{CH}_{3} \mathrm{OH}$ yield with S-g- $\mathrm{C}_{3} \mathrm{~N}_{4}$ was determined to be $1.12 \mu \mathrm{mol} \cdot \mathrm{g}^{-1}$, whereas for pristine $\mathrm{g}-\mathrm{C}_{3} \mathrm{~N}_{4}$ it was $0.81 \mu \mathrm{mol} \cdot \mathrm{g}^{-1}$. The photogenerated electrons captured in these defects can promote the charge 
transfer and separation. The inhibition of the electron-hole recombination and prolongation of the lifetime of charge carriers occurs.

Overall, the $\mathrm{O}, \mathrm{N}, \mathrm{S}$, and P-doped g- $\mathrm{C}_{3} \mathrm{~N}_{4}$ demonstrated the enhanced activity in the $\mathrm{CO}_{2}$ photocatalytic reduction by improving the energy band structure that allowed more effective light trapping in the visible light region of spectra. The nonmetal element doping caused the formation of an impurity level in $\mathrm{g}_{-} \mathrm{C}_{3} \mathrm{~N}_{4}$, which favored the charge transfer. Moreover, the surface groups, which are introduced by the doping process, enhanced the $\mathrm{CO}_{2}$ adsorption due to acid-base interactivity.

\section{2. $\mathrm{H}_{2}$-Evolution}

The graphitic carbon nitride presents a great potential for realizing hydrogen evolution reactions. The introduction of non-metal elements caused the exfoliation of bulk g- $\mathrm{C}_{3} \mathrm{~N}_{4}$ into ultrathin nanosheets, activated the basal plane of $\mathrm{g}-\mathrm{C}_{3} \mathrm{~N}_{4}$, and improved the intrinsic electronic conductivity, thus implementing the facilitated $\mathrm{H}_{2}$ production.

The activity of the C-g- $\mathrm{C}_{3} \mathrm{~N}_{4}$ composite fabricated by Cao et al. was evaluated by the production of $\mathrm{H}_{2}$ under visible light irradiation and compared with pristine $\mathrm{g}-\mathrm{C}_{3} \mathrm{~N}_{4}$ [71]. The $\mathrm{H}_{2}$ evolution rate using C-g- $\mathrm{C}_{3} \mathrm{~N}_{4}(8.88 \mu \mathrm{mol} / \mathrm{h})$ was 5.2 times higher that of $\mathrm{g}-\mathrm{C}_{3} \mathrm{~N}_{4}\left(1.70 \mu \mathrm{mol} \cdot \mathrm{h}^{-1}\right)$ due to the improvement of separation of photoexcited carriers and the enhanced utilization of visible light efficiency. The advantages of $\mathrm{C}-\mathrm{g}-\mathrm{C}_{3} \mathrm{~N}_{4}$ were responsible for its drastic photocatalytic activity, such as the ability to separate more photoinduced electrons of $\mathrm{CB}$ and holes of VB under irradiation and the presence of delocalized $\pi$ bonds, which reduce the barrier of charge carrier transfer and enhance electron transportation (Figure 11). The bridging nitrogen atoms of pristine g- $\mathrm{C}_{3} \mathrm{~N}_{4}$ are unable to form conjugation with ambient carbon atoms due to inconsequent and small area of $\pi$ conjugated system in pristine $\mathrm{g}-\mathrm{C}_{3} \mathrm{~N}_{4}$. Thus, under irradiation of $\mathrm{C}-\mathrm{g}-\mathrm{C}_{3} \mathrm{~N}_{4}$, more and faster electrons were formed to participate in the process of hydrogen evolution.

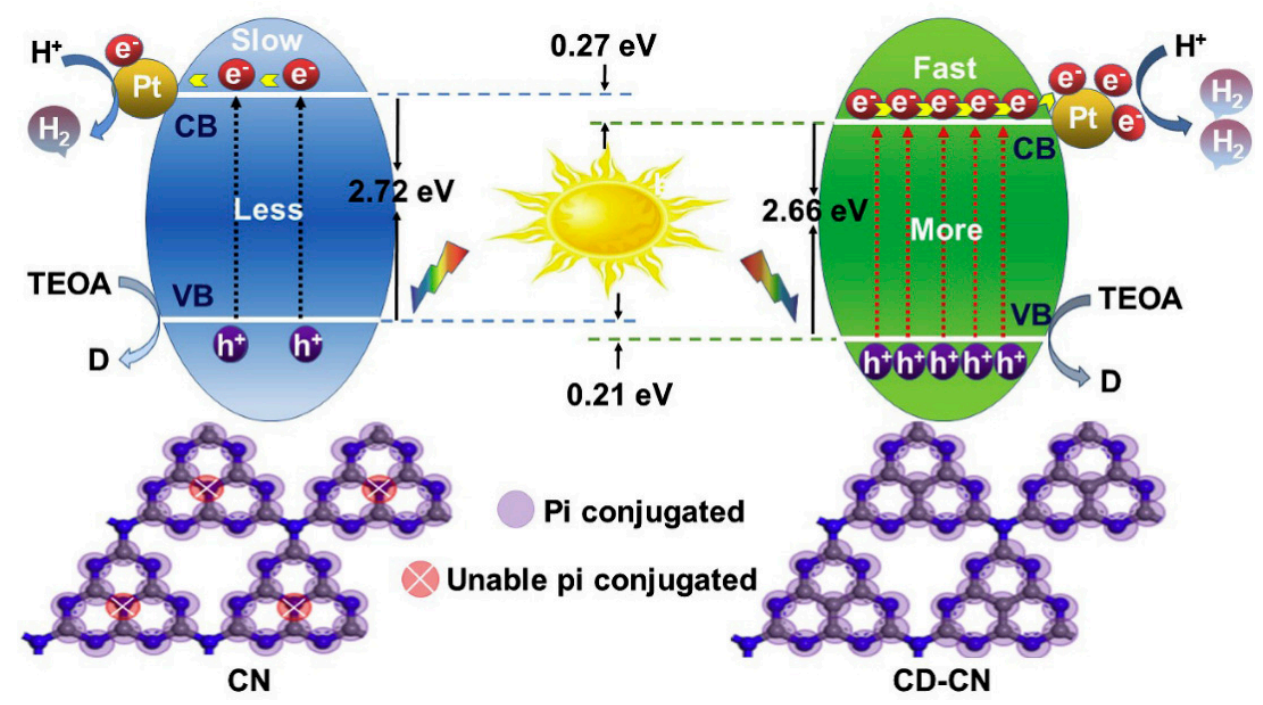

Figure 11. Proposed mechanism for Pt-deposited $g-\mathrm{C}_{3} \mathrm{~N}_{4}(\mathrm{CN})$ and $\mathrm{C}-\mathrm{g}-\mathrm{C}_{3} \mathrm{~N}_{4}(\mathrm{CD}-\mathrm{CN})$ of visible-light photocatalytic performance; TEOA is triethanolamine and D is oxidation products. Reprinted from [71] Copyright (2020), with permission from Elsevier.

O-g- $\mathrm{C}_{3} \mathrm{~N}_{4}$ with the various content of oxygen was tested for the photocatalytic hydrogen evolution reactions to study the dependence of photocatalytic activity of $\mathrm{O}-\mathrm{g}-\mathrm{C}_{3} \mathrm{~N}_{4}$ on oxygen coverage [24]. The reaction was performed at atmospheric pressure using $\mathrm{N}_{2}$ as a gas carrier in the presence of a hole scavenger and Pt cocatalyst under irradiation by a Xe lamp fitted with a filter to simulate solar light. The increasing of the $\mathrm{O}-\mathrm{g}-\mathrm{C}_{3} \mathrm{~N}_{4}$ photocatalytic activity was observed in the sequence of surface $\mathrm{O}$ at.\% compositions $3.6>3.2>0>5.4>6.6$. The authors observed a competing dual effect of oxygen doping 
on the photocatalytic activity. On one hand, the enhanced light harvesting capability was influenced by the higher porosity of O-g- $\mathrm{C}_{3} \mathrm{~N}_{4}$ and sub-gap impurity states formed by oxygen in its electronic band structure. Although, at the lower oxygen levels the dopant effectively captured and mediated the interfacial charge transfer that promoted the $\mathrm{H}_{2}$ evolution. On the other hand, the impurity levels from high-density oxygen groups become detrimental to the photoactivity of O-g- $\mathrm{C}_{3} \mathrm{~N}_{4}$. These levels acted as recombination centers due to their positions closer to central position of the band gap.

$\mathrm{O}-\mathrm{g}-\mathrm{C}_{3} \mathrm{~N}_{4}$ obtained by the thermal polymerization of a purposefully designed precursor with increased photoreduction capability demonstrated the notable enhancement of hydrogen evolution under visible light irradiation [42]. The average hydrogen evolution rate was $64.30 \mu \mathrm{mol} \cdot \mathrm{h}^{-1}$, which is 17.8 times higher in comparison with $3.60 \mu \mathrm{mol} / \mathrm{h}$ of g- $\mathrm{C}_{3} \mathrm{~N}_{4}$.

$\mathrm{C}_{60}-\mathrm{g}-\mathrm{C}_{3} \mathrm{~N}_{4}$ nanowire composites obtained by Long et al. through the calcination of urea and a $\mathrm{C}_{60}$ nanorods mixture demonstrated the higher activity in the photocatalytic $\mathrm{H}_{2}$ evolution process compared to pristine g- $\mathrm{C}_{3} \mathrm{~N}_{4}$ [76]. Due to the band gap of $\mathrm{g}-\mathrm{C}_{3} \mathrm{~N}_{4}$ reduced by incorporation of $\mathrm{C}_{60}$, the charge carriers of $\mathrm{C}_{60}-\mathrm{g}-\mathrm{C}_{3} \mathrm{~N}_{4}$ nanowire composites became easily excited with visible light. The delocalized $\pi$ structure of $C_{60}$ promoted the photoinduced electron transfer and acted as effective electron acceptor. The irradiation of $\mathrm{C}_{60}-\mathrm{g}-\mathrm{C}_{3} \mathrm{~N}_{4}$ composites caused the $\mathrm{CB}$ photogenerated electrons transfer to $\mathrm{C}_{60}$, which resulted in the effective hole-electron separation. These separated charges were trapped by surface adsorbates to produce highly reactive radicals. The proton reduction to $\mathrm{H}_{2}$ occurred with electrons accumulated on $\mathrm{C}_{60}$, thus optimizing the $\mathrm{H}_{2}$ production. The $\mathrm{H}_{2}$ evolution rate for the $\mathrm{C}_{60}-\mathrm{g}-\mathrm{C}_{3} \mathrm{~N}_{4}$ nanowire composite was about 4.7 times higher than for pristine $\mathrm{g}-\mathrm{C}_{3} \mathrm{~N}_{4}$. The hydrogen was produced with the rate of $8.73 \mu \mathrm{mol} / \mathrm{h}$ at $5.10 \%$ of quantum efficiency in the presence of $\mathrm{C}_{60}-\mathrm{g}-\mathrm{C}_{3} \mathrm{~N}_{4}$.

The $\mathrm{H}_{2}$-evolution under visible light-inducing water splitting was performed to study the photocatalytic activity of $\mathrm{N}-\mathrm{g}-\mathrm{C}_{3} \mathrm{~N}_{4}$ [63]. The authors used $3 \mathrm{wt} . \% \mathrm{Pt}$ as a co-catalyst and $10 \mathrm{vol} \%$ triethanolamine as a hole sacrificial agent. The hydrogen evolution performance of $\mathrm{N}-\mathrm{g}-\mathrm{C}_{3} \mathrm{~N}_{4}$ was 4.3 times higher in comparison with pristine g- $\mathrm{C}_{3} \mathrm{~N}_{4}$. The doped $\mathrm{N}$ atoms were supposed to promote the separation and transfer of charge carriers and inhibit their recombination. N-g- $\mathrm{C}_{3} \mathrm{~N}_{4}$ demonstrated its high stability after four cycles of the photocatalytic experiments.

Guo et al. suggested the improved optical absorption properties of $\mathrm{N}-\mathrm{g}-\mathrm{C}_{3} \mathrm{~N}_{4}$ that was obtained by the copolymerization of urea with DMF and the decreased band-gap facilitated harvesting of visible light and increased photocatalytic activity [51]. The more negative conduction band potential of obtained $\mathrm{N}-\mathrm{g}-\mathrm{C}_{3} \mathrm{~N}_{4}$ resulted in the improved reducing ability of photoelectrons, thus promoting the photocatalytic water splitting for $\mathrm{H}_{2}$ evolution. The rate of photocatalytic hydrogen production was 14 times higher than that of pristine $\mathrm{g}-\mathrm{C}_{3} \mathrm{~N}_{4}$.

Tian et al. studied the photocatalytic performance of mesoporous $\mathrm{N}-\mathrm{g}-\mathrm{C}_{3} \mathrm{~N}_{4}$ materials obtained via the pre-hydrothermal treatment of urea and melamine for the photocatalytic $\mathrm{H}_{2}$ production under visible light irradiation [64]. The authors used $20 \mathrm{vol} \%$ lactic acid as a sacrificial agent and $1 \% \mathrm{Pt}$ as a co-catalyst. The increased $\mathrm{H}_{2}$ evolution activity was observed for all the doped samples. The positive effect of melamine phase-transformation was observed even for $\mathrm{N}-\mathrm{g}-\mathrm{C}_{3} \mathrm{~N}_{4}$ obtained without urea that demonstrated the photocatalytic $\mathrm{H}_{2}$ production rate of 1.7 times higher than that of pristine g- $\mathrm{C}_{3} \mathrm{~N}_{4}$. The highest photocatalytic performance with the $\mathrm{H}_{2}$ evolution rate of $3579 \mu \mathrm{mol} \cdot \mathrm{h}^{-1} \cdot \mathrm{g}^{-1}$ was observed for the sample with the molar ratio of urea: melamine $=3: 1$, which was 23 times higher than that of $\mathrm{g}-\mathrm{C}_{3} \mathrm{~N}_{4}$. Consistent results were also obtained for the $\mathrm{H}_{2}$ evolution in the absence of $\mathrm{Pt}$ while maintaining other conditions to be similar. The sample with the molar ratio of urea: melamine $=0: 1$ and $3: 1$ demonstrated the $\mathrm{H}_{2}$ evolution rate of 1.9 and 15 times higher than that of pristine g- $\mathrm{C}_{3} \mathrm{~N}_{4}$. The authors identified three factors that caused the high photocatalytic activity of the 3D ultrathin porous $\mathrm{N}-\mathrm{g}-\mathrm{C}_{3} \mathrm{~N}_{4}$ materials: Firstly, the increased specific surface area originated from porous nanosheets that contained more reaction sites. Secondly, the narrowed band gap allowed more visible-light absorption and improved the $\mathrm{H}_{2}$ evolution ability. Thirdly, the significant reduction of recombination rate of photogenerated electrons and holes by porous structure of $\mathrm{N}-\mathrm{g}-\mathrm{C}_{3} \mathrm{~N}_{4}$ improved 
the charge separation and rapid movement of charge carriers to the surface of photocatalyst where the reduction process occurred.

$\mathrm{N}$ vacancies-doped g- $\mathrm{C}_{3} \mathrm{~N}_{4}$ with increased crystallinity and boosted visible-light harvesting demonstrated improved performance of the photocatalytic $\mathrm{H}_{2}$ evolution [133]. The hydrogen evolution rate $5833.1 \mu \mathrm{mol} \cdot \mathrm{h}^{-1} \cdot \mathrm{g}^{-1}$ compared to $1447.8 \mu \mathrm{mol} \cdot \mathrm{h}^{-1} \cdot \mathrm{g}^{-1}$ of pristine $\mathrm{g}-\mathrm{C}_{3} \mathrm{~N}_{4}$. The $\mathrm{V}-\mathrm{g}-\mathrm{C}_{3} \mathrm{~N}_{4}$ photocatalyst had high chemical stability even after five cycles of the continuous photocatalytic reaction.

The theoretical and experimental study of the effect of intra- and inter-triazine $\mathrm{N}$-vacancies in g- $\mathrm{C}_{3} \mathrm{~N}_{4}$ on the photocatalytic $\mathrm{H}_{2}$ evolution activity was carried out by Li et al. [88]. The singly occupied defect states, which were formed in the band gap of $\mathrm{g}-\mathrm{C}_{3} \mathrm{~N}_{4}$ by both types of $\mathrm{N}$ vacancies, trapped the photogenerated electrons and served as centers of the $\mathrm{H}^{+}$reduction. The most efficient $\mathrm{H}_{2}$ evolution was observed for $\mathrm{V}-\mathrm{g}-\mathrm{C}_{3} \mathrm{~N}_{4}$ with the inter-triazine vacancies compared to $\mathrm{V}-\mathrm{g}-\mathrm{C}_{3} \mathrm{~N}_{4}$ with the intra-triazine vacancies due to stronger electron localization. The normalized reaction rate of inter-triazine V-g- $\mathrm{C}_{3} \mathrm{~N}_{4}$ was 9 times higher than that of "vacancy-free" $\mathrm{g}-\mathrm{C}_{3} \mathrm{~N}_{4}$, and 2.2 times higher than that of intra-triazine $\mathrm{V}-\mathrm{g}-\mathrm{C}_{3} \mathrm{~N}_{4}$.

The SM-g- $\mathrm{C}_{3} \mathrm{~N}_{4}$ nanosheets demonstrated enhanced activity in the photocatalytic $\mathrm{H}_{2}$ production compared to pristine g- $\mathrm{C}_{3} \mathrm{~N}_{4}$ [103]. The average $\mathrm{H}_{2}$ evolution rate was 3.80 times higher than that of $g-\mathrm{C}_{3} \mathrm{~N}_{4}$. The study of $\mathrm{H}_{2}$ production under irradiation with the wavelengths of 420,450, 475, and $520 \mathrm{~nm}$ demonstrated that the activity of SM-g- $\mathrm{C}_{3} \mathrm{~N}_{4}$ corresponded to the optical absorption of the photocatalyst due to the band gap excitation. The only trace amount of $\mathrm{H}_{2}$ was produced with pristine g- $\mathrm{C}_{3} \mathrm{~N}_{4}$ when the irradiation light with the wavelength longer than $450 \mathrm{~nm}$ was applied.

In other research, the drastic increase of $\mathrm{H}_{2}$ evolution was reached with S-g- $\mathrm{C}_{3} \mathrm{~N}_{4}$ nanosheets [90]. The obtained S-doped materials possessed the increased SSA, higher efficiency in charge carrier separation, and enlarged band gap energy with the upward shift of the $\mathrm{CB}$ potential and the downward shift of VB potential. These factors caused the high $\mathrm{H}_{2}$ production rate of $127.4 \mu \mathrm{mol} \cdot \mathrm{h}^{-1}$, which is about 250 times higher than that for pristine g- $\mathrm{C}_{3} \mathrm{~N}_{4}$. There was a stronger reduction ability observed for the hydrogen evolution of electrons in the CB of S-g- $\mathrm{C}_{3} \mathrm{~N}_{4}$.

The great increase of photocatalytic activity in the $\mathrm{H}_{2}$ evolution under the visible-light irradiation was reached for the porous P-g- $\mathrm{C}_{3} \mathrm{~N}_{4}$ nanosheets [118]. The total $\mathrm{H}_{2}$ production for $4 \mathrm{~h}$ was 1813 and $30,281 \mu \mathrm{mol}$ for pristine g- $\mathrm{C}_{3} \mathrm{~N}_{4}$ and P-g- $\mathrm{C}_{3} \mathrm{~N}_{4}$, respectively. The photocatalytic $\mathrm{H}_{2}$ evolution rate was 458 and $9524 \mu \mathrm{mol}^{-1} \cdot \mathrm{h}^{-1}$, respectively. The obtained $\mathrm{P}-\mathrm{g}-\mathrm{C}_{3} \mathrm{~N}_{4}$ was stable over the five test cycles. The apparent quantum efficiency was calculated to be $5.49 \%, 2.67 \%, 1.01 \%$, and $0.17 \%$ at irradiation with $\lambda=400,420,450$, and $550 \mathrm{~nm}$, respectively. The enhancing of photocatalytic activity was reached due to the increased number of active sites for the photocatalytic $\mathrm{H}_{2}$ evolution provided by the porous structure and P-doping, the extending of light absorption range, and the improvement of hydrophilicity for easier water molecules adsorption via introducing $\mathrm{OH}$ groups. Additionally, the P-doping changed the excitation process and improved the efficiency of the charge separation.

The $\mathrm{O}, \mathrm{N}, \mathrm{S}$, and P doping is a useful strategy to modify the electronic structure of g- $\mathrm{C}_{3} \mathrm{~N}_{4}$ and to enhance the photocatalytic effect of hydrogen production. When the non-metal elements were applied to dope g- $\mathrm{C}_{3} \mathrm{~N}_{4}$, the $\mathrm{H}_{2}$ generation was increased due to the lowering of the charge recombination rate and accelerated charge mobility.

\subsection{Degradation of Dyes and Organic Pollutants}

The photocatalytic activity of O-g- $\mathrm{C}_{3} \mathrm{~N}_{4}$ was evaluated by the degradation of organic dyes Rhodamine B (RhB) and Methyl Orange (MO) under irradiation with simulated solar light [35]. Ninety-five percent of RhB $(10 \mathrm{mg} / \mathrm{L})$ was degraded in $20 \mathrm{~min}$ and $70 \%$ of $\mathrm{MO}(10 \mathrm{mg} / \mathrm{L})$ in $4 \mathrm{~h}$ in the presence of O-g- $\mathrm{C}_{3} \mathrm{~N}_{4}$. The determined rate constants were 65 times and 24 times higher than those of $\mathrm{g}-\mathrm{C}_{3} \mathrm{~N}_{4}$, for RhB and $\mathrm{MO}$ degradation, respectively. The significant improvement of photocatalytic activity was explained by the porous layered structure of O-g- $\mathrm{C}_{3} \mathrm{~N}_{4}$, its ability to reduce the recombination of photogenerated carriers, and increased absorption of visible light. Among the 
possible active species $\left(\mathrm{O}^{2 \bullet-}, \mathrm{OH}^{\bullet}, \mathrm{h}^{+}\right) \mathrm{O}^{2 \bullet-}$ and $\mathrm{h}^{+}$were main active species of the photocatalytic degradation of RhB that was confirmed by using sacrificial agents.

The photocatalytic decomposition of RhB under visible light was performed to determine the influence of oxidative treatment of $\mathrm{g}-\mathrm{C}_{3} \mathrm{~N}_{4}$ with PMS [17]. The dependence of the photocatalytic activity of the resulting O-g- $\mathrm{C}_{3} \mathrm{~N}_{4}$ on the amount of oxidant was found. Huang et al. determined the optimal amount of PMS for obtaining the $\mathrm{O}-\mathrm{g}-\mathrm{C}_{3} \mathrm{~N}_{4}$ photocatalyst with the highest activity for the decomposition of RhB under visible light. The mechanism of RhB decomposition is not the same as for non-selective degradation of the chromophore in $\mathrm{RhB}$ by hydroxyl radicals described in the papers [34,35]. It was found that the RhB photocatalytic degradation by O-g- $\mathrm{C}_{3} \mathrm{~N}_{4}$ occurred through $\mathrm{N}$-deethylation pathways. The study of the $\mathrm{RhB}$ degradation in the presence of various inhibitors of photoactive species formation confirmed that $\mathrm{O}_{2}{ }^{--}$was the dominant oxidant in the studied photocatalytic system (Figure 12).
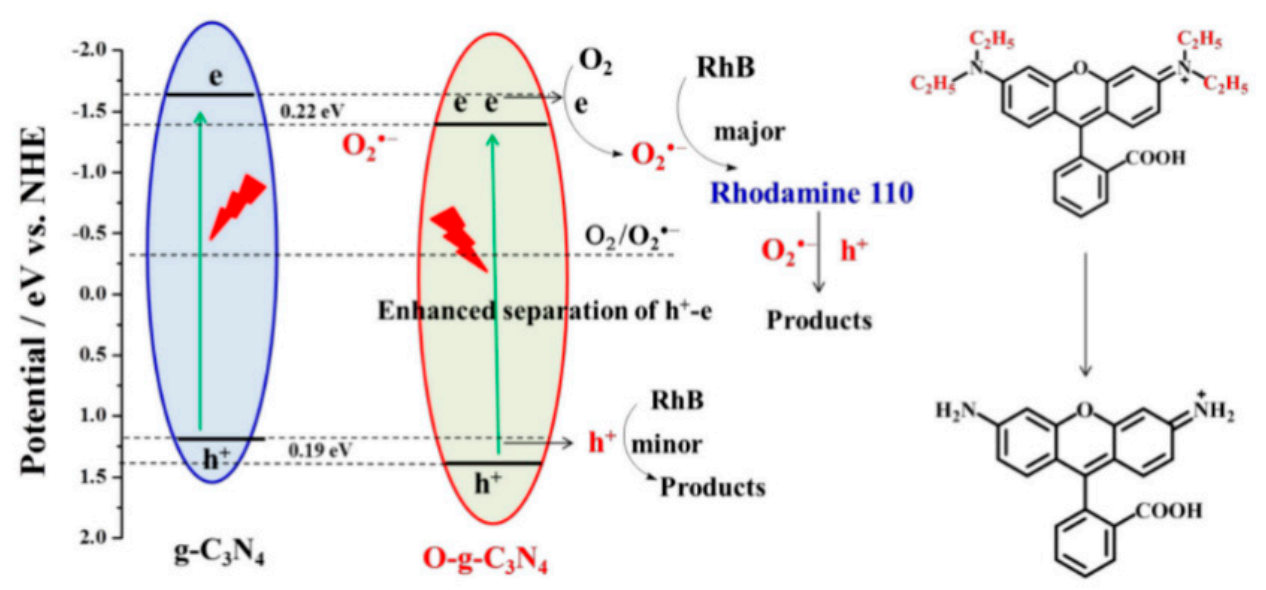

Figure 12. The scheme of the RhB photocatalytic degradation in the presence of $\mathrm{O}-\mathrm{g}-\mathrm{C}_{3} \mathrm{~N}_{4}$. Reprinted from [17].

A dual oxygen group $(\mathrm{C}-\mathrm{O}-\mathrm{C}$ and $\mathrm{C}=\mathrm{O})$ doped carbon nitride prepared by a two-step thermal treatment process demonstrated the remarkably enhanced visible-light photocatalytic performance for pollutant degradation [19]. Compounds, such as bisphenol, phenol, 2-chlorphenol, and diphenhydramine, were decomposed in their aqueous solutions using $g-\mathrm{C}_{3} \mathrm{~N}_{4}$. The improvement of the degradation rate occurred due to the formation of an internal electric field and strong interactions between the photocatalyst and organic contaminant. The authors proposed a possible electron transfer pathway for enhanced pollutant photodegradation. Photoexcited electrons moved to the dual oxygen groups together with further generation of $\mathrm{O}_{2}{ }^{\bullet-}$ that decomposed the pollutants. The pollutant adsorption caused the enhancement of internal electric field and greatly increased photogenerated $\mathrm{e}^{-} / \mathrm{h}^{+}$separation and transfer. As a result, the oxidation with $\mathrm{h}^{+}$and the generation of $\mathrm{O}_{2}{ }^{\bullet-}$ became more facile.

In other research, 49.3 times higher photocatalytic degradation efficiency of 4-nitrophenol using S-g- $\mathrm{C}_{3} \mathrm{~N}_{4}$ than that with pristine g- $\mathrm{C}_{3} \mathrm{~N}_{4}$ under visible light irradiation ( $>400 \mathrm{~nm}$ ) was demonstrated [107]. The enhanced photocatalytic activity was attributed to the nanosheets formation and sulfur modification. Chrysanthemum-like nanosheet structures of S-g- $\mathrm{C}_{3} \mathrm{~N}_{4}$ presented more active sites and improved its photochemical response. The sulfur modification induced the energy structure changes and lattice distortion. It was confirmed that the photocatalytic degradation of 4-nitrophenol by S-g- $\mathrm{C}_{3} \mathrm{~N}_{4}$ was greatly influenced by oxidative species, such as singlet oxygen.

The high photocatalytic activities toward removing organic pollutants were demonstrated for mesoporous $\mathrm{C}-\mathrm{g}-\mathrm{C}_{3} \mathrm{~N}_{4}$ ultrathin nanosheets synthesized through a facile one-step thermal condensation method with an agar-melamine gel precursor [79]. The more efficient ability of the nanosheets to remove RhB, phenol, Bisphenol A, and Phenanthrene compared to bulk g- $\mathrm{C}_{3} \mathrm{~N}_{4}$ under 
visible-light irradiation was reported. The $\mathrm{C}-\mathrm{g}-\mathrm{C}_{3} \mathrm{~N}_{4}$ ultrathin nanosheets demonstrated improved photoelectrochemical properties due to the strong enhancing of the photo-excited carriers' separation and migration. It was found that $\mathrm{O}_{2}{ }^{\bullet-}$ as well as $\mathrm{OH}^{\bullet}$ radicals were responsible for the strong oxidative capacity of the carbon doped photocatalysts, while for the pristine g- $_{3} \mathrm{~N}_{4}$ only $\mathrm{O}_{2}{ }^{\bullet-}$ radicals oxidized the pollutants. The abundant holes of the $\mathrm{VB} \mathrm{h}^{+}$directly oxidized the pollutants. The great improvement photocatalytic activity was assigned to synergy of doped carbon and ultrathin nanosheets structure. The incorporated carbon strengthened visible-light absorbance, promoted charge separation, and prevented the photogenerated carriers' recombination. The $\mathrm{C}-\mathrm{g}-\mathrm{C}_{3} \mathrm{~N}_{4}$ nanosheets provided more active sites for photocatalytic reactions.

The photocatalytic performance of $\mathrm{SM}-\mathrm{g}-\mathrm{C}_{3} \mathrm{~N}_{4}$ nanosheets under the visible light irradiation was tested for the degradation of dichlorotriazine dye used in textile crafts (Procion Red MX-5B) [103]. The highest activity in the process was observed for a sample with the highest SSA and narrowest bandgap. To determine the mechanism of the photocatalytic process the degradation of Procion Red MX-5B was performed with the most active photocatalysts in the presence of hole, $\mathrm{OH}$, and $\mathrm{O}_{2}{ }^{\bullet-}$ scavengers. The most active species in the photocatalytic decomposition of the dichlorotriazine dye was determined to be the $\mathrm{O}_{2}{ }^{\bullet-}$.

P-g- $\mathrm{C}_{3} \mathrm{~N}_{4}$ obtained by the thermo-induced copolymerization method from a low cost and environmentally friendly $\mathrm{P}$ precursor were tested in the $\mathrm{RhB}$ degradation under irradiation with visible light. Due to significant changes in the electronic, surface, and semiconductor properties of $g-C_{3} N_{4}$ after P-doping the improved photocatalytic performance of RhB degradation was confirmed [126]. $\mathrm{RhB}$ in the solution $\left(10 \mathrm{mg} \cdot \mathrm{L}^{-1}\right)$ was completely decomposed within $10 \mathrm{~min}$ while the decomposition of RhB solution of the same concentration lasted $30 \mathrm{~min}$ with pristine $\mathrm{g}-\mathrm{C}_{3} \mathrm{~N}_{4}$. The high ability of $\mathrm{P}-\mathrm{g}-\mathrm{C}_{3} \mathrm{~N}_{4}$ to adsorb RhB also influenced the improvement of photocatalytic performance.

The presented research reports demonstrated that the photocatalytic activity of non-metal element-doped g- $\mathrm{C}_{3} \mathrm{~N}_{4}$ has been greatly improved over pristine $\mathrm{g}-\mathrm{C}_{3} \mathrm{~N}_{4}$, and the degradation rates of organic dyes and pollutants have been enhanced to varying degrees. The doping of g- $\mathrm{C}_{3} \mathrm{~N}_{4}$ with $\mathrm{O}, \mathrm{N}$, $\mathrm{C}, \mathrm{S}$, and $\mathrm{P}$ elements resulted in materials with stronger light absorbance, faster charge migration rate, and more photoreaction sites, providing the increased photocatalytic reaction rate. The comparison of the photocatalytic activity of doped $\mathrm{g}-\mathrm{C}_{3} \mathrm{~N}_{4}$ in the reported processes can be done generally by the comparison of the photocatalytic rate constants. Because absorption of photons plays a key role in photocatalytic processes, the apparent quantum yield must be used for reporting and comparing photocatalytic activities, which corresponds to lower limits of the quantum yield [150].

\section{Conclusions}

In this review, we summarized the recent research progress in the non-metal doping of graphitic carbon nitride used mostly for photocatalysis. The overview was focused on the modulation of composition and morphology of g- $\mathrm{C}_{3} \mathrm{~N}_{4}$ with chemical doping with oxygen, sulfur, phosphor, nitrogen, carbon, as well as nitrogen and carbon vacancies. The efforts of various research groups to improve the photocatalytic activity of $\mathrm{g}-\mathrm{C}_{3} \mathrm{~N}_{4}$ in processes of the $\mathrm{CO}_{2}$ reduction, $\mathrm{H}_{2}$-evolution, and organic contaminants degradation by its non-metal doping were successful. Their results confirmed that g- $\mathrm{C}_{3} \mathrm{~N}_{4}$ is a universal, environmentally friendly, low-price, and stable material for creating new photocatalysts with targeted properties.

One of targets of the incorporation of non-metallic dopants into $g-\mathrm{C}_{3} \mathrm{~N}_{4}$ is the narrowing of the band gap, extending the sensitivity to the light of visible region as well as the reducing of recombination rate of electron-hole pairs for efficient charge separation that caused the enhancement of photocatalytic performances. However, in very few studies, a significant band gap reduction was observed after doping/modification with nonmetal atoms. In some cases, the efforts to modify pristine g- $\mathrm{C}_{3} \mathrm{~N}_{4}$ caused even band gap enlargement. It is important to perform the doping of non-metal atoms into $g-C_{3} N_{4}$ matrices to reach the effective band gap narrowing. The surface doping can only cause the formation of some band gap localized states. 
The prominent decreasing of the $\mathrm{PL}$ intensity of the majority of $\mathrm{O}-, \mathrm{C}-, \mathrm{N}-, \mathrm{S}-, \mathrm{P}-$, and vacancy-doped g- $\mathrm{C}_{3} \mathrm{~N}_{4}$ compared to the pristine g- $\mathrm{C}_{3} \mathrm{~N}_{4}$ confirmed their ability to inhibit charge recombination due to the capture of electrons by the dopants. However, the study of PL decay is rarely used for $\mathrm{g}^{-} \mathrm{C}_{3} \mathrm{~N}_{4}$ materials. Data on PL quenching can give quantitative characteristic of charge recombination inhibition processes. The creation of $\mathrm{g}-\mathrm{C}_{3} \mathrm{~N}_{4}$ materials with a strong visible light absorption and extremely low radiative recombination of excited charge carriers is still the target of future investigations.

It is well known that SSA has important characteristics of solid catalysts as it influences a number of reaction sites and the ability to absorb reaction products. The effect of active sites on the activity of g- $\mathrm{C}_{3} \mathrm{~N}_{4}$-based photocatalysts is unquestionable. The higher SSA of the materials provides more active sites, and enhances the transfer and separation of charges in photocatalytic processes. The SSA of pristine g- $\mathrm{C}_{3} \mathrm{~N}_{4}$ was strongly affected by synthesis methods. In some cases, the modification with non-metal atoms caused the increasing of SSA that enhanced their photocatalytic activity.

It should be mentioned that the relation between acid-base properties of $g-C_{3} N_{4}$ and non-metal elements doping and its influence on photocatalytic activity was not enlightened enough in the literature. The Bronsted and Lewis base centers are formed in the frame of $g-C_{3} \mathrm{~N}_{4}$ by uncondensed primary and tertiary amino groups, and aromatic amino groups of the three-s-triazine moieties. The presence of Lewis acid and base centers affected its application as active materials for dark catalysis and photocatalysis. The study of the connection between kinds of non-metal element doping and the acid-base properties of doped g- $\mathrm{C}_{3} \mathrm{~N}_{4}$ will allow us to develop new materials with targeted properties for the appropriate photocatalytic process.

Author Contributions: H.S. wrote the manuscript, P.P. finalized the manuscript. All authors have read and agreed to the published version of the manuscript.

Funding: This work was supported by the Czech Science Foundation (project No. 19-15199S), EU structural funding in Operational Program Research, Development and Education (project No. CZ.02.1.01/0.0/0.0/16_019/0000853 "IET-ER").

Conflicts of Interest: The authors declare no conflict of interest. The funders had no role in the design of the study; in the collection, analyses, or interpretation of data; in the writing of the manuscript, or in the decision to publish the results.

\section{References}

1. Wang, X.; Maeda, K.; Thomas, A.; Takanabe, K.; Xin, G.; Carlsson, J.M.; Domen, K.; Antonietti, M. A metal-free polymeric photocatalyst for hydrogen production from water under visible light. Nat. Mater. 2009, 8, 76-80. [CrossRef] [PubMed]

2. Dong, G.; Zhang, Y.; Pan, Q.; Qiu, J. A fantastic graphitic carbon nitride $\left(\mathrm{g}-\mathrm{C}_{3} \mathrm{~N}_{4}\right)$ material: Electronic structure, photocatalytic and photoelectronic properties. J. Photochem. Photobiol. C Photochem. Rev. 2014, 20, 33-50. [CrossRef]

3. Kroke, E. Novel group 14 nitrides. Coord. Chem. Rev. 2004, 248, 493-532. [CrossRef]

4. Ong, W.-J.; Tan, L.-L.; Ng, Y.H.; Yong, S.-T.; Chai, S.-P. Graphitic Carbon Nitride $\left(\mathrm{g}_{-} \mathrm{C}_{3} \mathrm{~N}_{4}\right)$-Based Photocatalysts for Artificial Photosynthesis and Environmental Remediation: Are We a Step Closer To Achieving Sustainability? Chem. Rev. 2016, 116, 7159-7329. [CrossRef] [PubMed]

5. Hasija, V.; Raizada, P.; Sudhaik, A.; Sharma, K.; Kumar, A.; Singh, P.; Jonnalagadda, S.B.; Thakur, V.K. Recent advances in noble metal free doped graphitic carbon nitride based nanohybrids for photocatalysis of organic contaminants in water: A review. Appl. Mater. Today 2019, 15, 494-524. [CrossRef]

6. Zhou, Z.; Zhang, Y.; Shen, Y.; Liu, S.; Zhang, Y. Molecular engineering of polymeric carbon nitride: Advancing applications from photocatalysis to biosensing and more. Chem. Soc. Rev. 2018, 47, 2298-2321. [CrossRef]

7. Wang, A.; Wang, C.; Fu, L.; Wong-Ng, W.; Lan, Y. Recent Advances of Graphitic Carbon Nitride-Based Structures and Applications in Catalyst, Sensing, Imaging, and LEDs. Nano-Micro Lett. 2017, 9, 47. [CrossRef]

8. Masih, D.; Ma, Y.; Rohani, S. Graphitic $\mathrm{C}_{3} \mathrm{~N}_{4}$ based noble-metal-free photocatalyst systems: A review. Appl. Catal. B Environ. 2017, 206, 556-588. [CrossRef]

9. $\mathrm{Fu}, \mathrm{J} . ; \mathrm{Yu}, \mathrm{J} . ;$ Jiang, C.; Cheng, B. g- $\mathrm{C}_{3} \mathrm{~N}_{4}$-Based Heterostructured Photocatalysts. Adv. Energy Mater. 2018, 8 , 1701503, (1-31). [CrossRef] 
10. Zhao, Z.; Sun, Y.; Dong, F. Graphitic carbon nitride based nanocomposites: A review. Nanoscale 2015, 7, 15-37. [CrossRef]

11. Chen, W.; Jiang, D.; Zhu, M.Y.; Shi, T.Y.; Li, H.N.; Wang, K. An effective strategy for fabricating highly dispersed nanoparticles on $\mathrm{O}-\mathrm{C}_{3} \mathrm{~N}_{4}$ with enhanced electrocatalytic activity and stability. J. Alloy. Compd. 2018, 741, 1203-1211. [CrossRef]

12. Yousefi, M.; Villar-Rodil, S.; Paredes, J.I.; Moshfegh, A.Z. Oxidized graphitic carbon nitride nanosheets as an effective adsorbent for organic dyes and tetracycline for water remediation. J. Alloy. Compd. 2019, 809, 11. [CrossRef]

13. Zhu, W.R.; Hao, N.; Lu, J.W.; Dai, Z.; Qian, J.; Yang, X.D.; Wang, K. Highly active metal-free peroxidase mimics based on oxygen-doped carbon nitride by promoting electron transfer capacity. Chem. Commun. 2020, 56, 1409-1412. [CrossRef] [PubMed]

14. Chubenko, E.B.; Baglov, A.V.; Leonenya, M.S.; Yablonskii, G.P.; Borisenko, V.E. Structure of Photoluminescence Spectra of Oxygen-Doped Graphitic Carbon Nitride. J. Appl. Spectrosc. 2020, 87, 9-14. [CrossRef]

15. Denisov, N.M.; Chubenko, E.B.; Bondarenko, V.P.; Borisenko, V.E. Synthesis of Oxygen-Doped Graphitic Carbon Nitride from Thiourea. Tech. Phys. Lett. 2019, 45, 108-110. [CrossRef]

16. Gao, Y.W.; Zhu, Y.; Lyu, L.; Zeng, Q.Y.; Xing, X.C.; Hu, C. Electronic Structure Modulation of Graphitic Carbon Nitride by Oxygen Doping for Enhanced Catalytic Degradation of Organic Pollutants through Peroxymonosulfate Activation. Environ. Sci. Technol. 2018, 52, 14371-14380. [CrossRef]

17. Huang, J.; Nie, G.; Ding, Y.B. Metal-Free Enhanced Photocatalytic Activation of Dioxygen by g- $\mathrm{C}_{3} \mathrm{~N}_{4}$ Doped with Abundant Oxygen-Containing Functional Groups for Selective N-Deethylation of Rhodamine B. Catalysts 2020, 10, 6. [CrossRef]

18. Huang, T.; Pan, S.G.; Shi, L.L.; Yu, A.P.; Wang, X.; Fu, Y.S. Hollow porous prismatic graphitic carbon nitride with nitrogen vacancies and oxygen doping: A high-performance visible light-driven catalyst for nitrogen fixation. Nanoscale 2020, 12, 1833-1841. [CrossRef]

19. Li, F.; Han, M.E.; Jin, Y.; Zhang, L.L.; Li, T.; Gao, Y.W.; Hu, C. Internal electric field construction on dual oxygen group-doped carbon nitride for enhanced photodegradation of pollutants under visible light irradiation. Appl. Catal. B Environ. 2019, 256, 10. [CrossRef]

20. Liu, C.Y.; Huang, H.W.; Cui, W.; Dong, F.; Zhang, Y.H. Band structure engineering and efficient charge transport in oxygen substituted $\mathrm{g}-\mathrm{C}_{3} \mathrm{~N}_{4}$ for superior photocatalytic hydrogen evolution. Appl. Catal. B Environ. 2018, 230, 115-124. [CrossRef]

21. Li, Q.; Wang, S.C.; Sun, Z.X.; Tang, Q.J.; Liu, Y.Q.; Wang, L.Z.; Wang, H.Q.; Wu, Z.B. Enhanced CH $\mathrm{CH}_{4}$ selectivity in $\mathrm{CO}_{2}$ photocatalytic reduction over carbon quantum dots decorated and oxygen doping $\mathrm{g}-\mathrm{C}_{3} \mathrm{~N}_{4}$. Nano Res. 2019, 12, 2749-2759. [CrossRef]

22. Wei, F.Y.; Liu, Y.; Zhao, H.; Ren, X.N.; Liu, J.; Hasan, T.; Chen, L.H.; Li, Y.; Su, B.L. Oxygen self-doped g-C ${ }_{3} \mathrm{~N}_{4}$ with tunable electronic band structure for unprecedentedly enhanced photocatalytic performance. Nanoscale 2018, 10, 4515-4522. [CrossRef] [PubMed]

23. Chen, H.; Yao, J.H.; Qiu, P.X.; Xu, C.M.; Jiang, F.; Wang, X. Facile surfactant assistant synthesis of porous oxygen-doped graphitic carbon nitride nanosheets with enhanced visible light photocatalytic activity. Mater. Res. Bull. 2017, 91, 42-48. [CrossRef]

24. Putri, L.K.; Ng, B.J.; Er, C.C.; Ong, W.J.; Chang, W.S.; Mohamed, A.R.; Chai, S.P. Insights on the impact of doping levels in oxygen-doped $\mathrm{gC}(3) \mathrm{N}(4)$ and its effects on photocatalytic activity. Appl. Surf. Sci. 2020, 504. [CrossRef]

25. Sun, S.D.; Li, J.; Cui, J.; Gou, X.F.; Yang, Q.; Liang, S.H.; Yang, Z.M.; Zhang, J.M. Constructing oxygen-doped g- $\mathrm{C}_{3} \mathrm{~N}_{4}$ nanosheets with an enlarged conductive band edge for enhanced visible-light-driven hydrogen evolution. Inorg. Chem. Front. 2018, 5, 1721-1727. [CrossRef]

26. Chen, Y.L.; Liu, X.Q.; Hou, L.; Guo, X.R.; Fu, R.W.; Sun, J.M. Construction of covalent bonding oxygen-doped carbon nitride/graphitic carbon nitride Z-scheme heterojunction for enhanced visible-light-driven $\mathrm{H}_{2}$ evolution. Chem. Eng. J. 2020, 383. [CrossRef]

27. Sun, Z.Z.; Wang, W.; Chen, Q.W.; Pu, Y.Y.; He, H.; Zhuang, W.M.; He, J.Q.; Huang, L.M. A hierarchical carbon nitride tube with oxygen doping and carbon defects promotes solar-to-hydrogen conversion. J. Mater. Chem. A 2020, 8, 3160-3167. [CrossRef] 
28. Yuan, X.J.; Xie, R.L.; Zhang, Q.; Sun, L.; Long, X.J.; Xia, D.S. Oxygen functionalized graphitic carbon nitride as an efficient metal-free ozonation catalyst for atrazine removal: Performance and mechanism. Sep. Purif. Technol. 2019, 211, 823-831. [CrossRef]

29. Zeng, Y.X.; Liu, X.; Liu, C.B.; Wang, L.L.; Xia, Y.C.; Zhang, S.Q.; Luo, S.L.; Pei, Y. Scalable one-step production of porous oxygen-doped $\mathrm{g}-\mathrm{C}_{3} \mathrm{~N}_{4}$ nanorods with effective electron separation for excellent visible-light photocatalytic activity. Appl. Catal. B Environ. 2018, 224, 1-9. [CrossRef]

30. Zhang, C.; Zhang, M.Y.; Li, Y.; Shuai, D.M. Visible-light-driven photocatalytic disinfection of human adenovirus by a novel heterostructure of oxygen-doped graphitic carbon nitride and hydrothermal carbonation carbon. Appl. Catal. B Environ. 2019, 248, 11-21. [CrossRef]

31. Wang, Y.X.; Wang, H.; Chen, F.Y.; Cao, F.; Zhao, X.H.; Meng, S.G.; Cui, Y.J. Facile synthesis of oxygen doped carbon nitride hollow microsphere for photocatalysis. Appl. Catal. B Environ. 2017, 206, 417-425. [CrossRef]

32. Mei, R.G.; Ma, L.; An, L.A.; Wang, F.; Xi, J.J.; Sun, H.Y.; Luo, Z.K.; Wu, Q.X. Layered Spongy-like O-Doped g- $\mathrm{C}_{3} \mathrm{~N}_{4}$ : An Efficient Non-Metal Oxygen Reduction Catalyst for Alkaline Fuel Cells. J. Electrochem. Soc. 2017, 164, F354-F363. [CrossRef]

33. Wang, C.; Fan, H.Q.; Ren, X.H.; Ma, J.W.; Fang, J.W.; Wang, W.J. Hydrothermally Induced Oxygen Doping of Graphitic Carbon Nitride with a Highly Ordered Architecture and Enhanced Photocatalytic Activity. Chemsuschem 2018, 11, 700-708. [CrossRef] [PubMed]

34. Wang, H.; Guan, Y.H.; Hu, S.Z.; Pei, Y.B.; Ma, W.T.; Fan, Z.P. Hydrothermal Synthesis of Band Gap-Tunable Oxygen-Doped g- $\mathrm{C}_{3} \mathrm{~N}_{4}$ with Outstanding "Two-Channel" Photocatalytic H2O2 Production Ability Assisted by Dissolution-Precipitation Process. Nano 2019, 14. [CrossRef]

35. Zhang, B.; Li, X.J.; Zhao, Y.; Song, H.; Wang, H. Facile synthesis of oxygen doped mesoporous graphitic carbon nitride with high photocatalytic degradation efficiency under simulated solar irradiation. In Colloids and Surfaces a-Physicochemical and Engineering Aspects; Elsevier: Amsterdam, The Netherlands, 2019; Volume 580. [CrossRef]

36. Zhang, J.W.; Gong, S.; Mahmood, N.; Pan, L.; Zhang, X.W.; Zou, J.J. Oxygen-doped nanoporous carbon nitride via water-based homogeneous supramolecular assembly for photocatalytic hydrogen evolution. Appl. Catal. B Environ. 2018, 221, 9-16. [CrossRef]

37. Zhu, K.; Ouyang, J.; Liu, J.M.; Zhu, Y.X.; Zeng, Q.; Cui, Y.J. Preparation and Photocatalytic Hydrogen Evolution from Water of Oxygen Doped Carbon Nitride Nanosheets. Chin. J. Inorg. Chem. 2019, 35, 1005-1012. [CrossRef]

38. Zhu, Y.; Chen, Z.H.; Gao, Y.W.; Hu, C. General synthesis of carbon and oxygen dual-doped graphitic carbon nitride via copolymerization for non-photochemical oxidation of organic pollutant. J. Hazard. Mater. 2020, 394. [CrossRef]

39. Tang, R.; Ding, R.L.; Xie, X.C. Preparation of oxygen-doped graphitic carbon nitride and its visible-light photocatalytic performance on bisphenol A degradation. Water Sci. Technol. 2018, 78, 1023-1033. [CrossRef]

40. Wang, Y.X.; Rao, L.; Wang, P.F.; Guo, Y.; Guo, X.; Zhang, L.X. Porous oxygen-doped carbon nitride: Supramolecular preassembly technology and photocatalytic degradation of organic pollutants under low-intensity light irradiation. Environ. Sci. Pollut. Res. 2019, 26, 15710-15723. [CrossRef]

41. Zhang, S.; Liu, Y.; Gu, P.C.; Ma, R.; Wen, T.; Zhao, G.X.; Li, L.; Ai, Y.J.; Hu, C.; Wang, X.K. Enhanced photodegradation of toxic organic pollutants using dual-oxygen-doped porous $\mathrm{g}_{-} \mathrm{C}_{3} \mathrm{~N}_{4}$ : Mechanism exploration from both experimental and DFT studies. Appl. Catal. B Environ. 2019, 248, 1-10. [CrossRef]

42. Song, P.; Liang, S.H.; Cui, J.; Ren, D.; Duan, R.Y.; Yang, Q.; Sun, S.D. Purposefully designing novel hydroxylated and carbonylated melamine towards the synthesis of targeted porous oxygen-doped g- $\mathrm{C}_{3} \mathrm{~N}_{4}$ nanosheets for highly enhanced photocatalytic hydrogen production. Catal. Sci. Technol. 2019, 9, 5150-5159. [CrossRef]

43. Fu, J.W.; Zhu, B.C.; Jiang, C.J.; Cheng, B.; You, W.; Yu, J.G. Hierarchical Porous O-Doped g-C ${ }_{3} \mathrm{~N}_{4}$ with Enhanced Photocatalytic $\mathrm{CO}_{2}$ Reduction Activity. Small 2017, 13, 9. [CrossRef] [PubMed]

44. Miller, D.R.; Wang, J.J.; Gillan, E.G. Rapid, facile synthesis of nitrogen-rich carbon nitride powders. J. Mater. Chem. 2002, 12, 2463-2469. [CrossRef]

45. Miller, D.R.; Swenson, D.C.; Gillan, E.G. Synthesis and structure of 2,5,8-triazido-s-heptazine: An energetic and luminescent precursor to nitrogen-rich carbon nitrides. J. Am. Chem. Soc. 2004, 126, 5372-5373. [CrossRef] 
46. Miller, D.R.; Holst, J.R.; Gillan, E.G. Nitrogen-rich carbon nitride network materials via the thermal decomposition of 2,5,8-triazido-s-heptazine. Inorg. Chem. 2007, 46, 2767-2774. [CrossRef]

47. Huynh, M.H.V.; Hiskey, M.A.; Archuleta, J.G.; Roemer, E.L.; Gilardi, R. 3,6-di(azido)-1,2,4,5-tetrazine: A precursor for the preparation of carbon nanospheres and nitrogen-rich carbon nitrides. Angew. Chem. Int. Edit. 2004, 43, 5658-5661. [CrossRef]

48. Gillan, E.G. Synthesis of nitrogen-rich carbon nitride networks from an energetic molecular azide precursor. Chem. Mat. 2000, 12, 3906-3912. [CrossRef]

49. Fang, J.W.; Fan, H.Q.; Li, M.M.; Long, C.B. Nitrogen self-doped graphitic carbon nitride as efficient visible light photocatalyst for hydrogen evolution. J. Mater. Chem. A 2015, 3, 13819-13826. [CrossRef]

50. Xu, Q.X.; Xu, G.Q.; Yu, Q.B.; Yang, K.; Li, H.Q. Nitrogen self-doped high specific surface area graphite carbon nitride for photocatalytic degradating of methylene blue. J. Nanopart. Res. 2019, 21, 13. [CrossRef]

51. Guo, F.; Wang, L.J.; Sun, H.R.; Li, M.Y.; Shi, W.L. High-efficiency photocatalytic water splitting by a $\mathrm{N}$-doped porous $\mathrm{g}-\mathrm{C}_{3} \mathrm{~N}_{4}$ nanosheet polymer photocatalyst derived from urea and $\mathrm{N}, \mathrm{N}$-dimethylformamide. Inorg. Chem. Front. 2020, 7, 1770-1779. [CrossRef]

52. Jiang, L.B.; Yuan, X.Z.; Zeng, G.M.; Liang, J.; Wu, Z.B.; Yu, H.B.; Mo, D.; Wang, H.; Xiao, Z.H.; Zhou, C.Y. Nitrogen self-doped $g-\mathrm{C}_{3} \mathrm{~N}_{4}$ nanosheets with tunable band structures for enhanced photocatalytic tetracycline degradation. J. Colloid Interface Sci. 2019, 536, 17-29. [CrossRef] [PubMed]

53. Wang, H.H.; Li, Q.; Zhang, S.; Chen, Z.S.; Wang, W.X.; Zhao, G.X.; Zhuang, L.; Hu, B.W.; Wang, X.K. Visible-light-driven $\mathrm{N}-2-\mathrm{g}-\mathrm{C}_{3} \mathrm{~N}_{4}$ as a highly stable and efficient photocatalyst for bisphenol A and $\mathrm{Cr}(\mathrm{VI})$ removal in binary systems. Catal. Today 2019, 335, 110-116. [CrossRef]

54. Dong, S.S.; Liu, C.; Chen, Y.G. Boosting exciton dissociation and molecular oxygen activation by in-plane grafting nitrogen-doped carbon nanosheets to graphitic carbon nitride for enhanced photocatalytic performance. J. Colloid Interface Sci. 2019, 553, 59-70. [CrossRef] [PubMed]

55. Qi, H.L.; Liu, Y.N.; Li, C.Y.; Zou, X.H.; Huang, Y.D.; Wang, Y.G. Precursor-reforming protocol to synthesis of porous $\mathrm{N}$-doped $\mathrm{g}-\mathrm{C}_{3} \mathrm{~N}_{4}$ for highly improved photocatalytic water treatments. Mater. Lett. 2020, $264,4$. [CrossRef]

56. Che, H.N.; Che, G.B.; Zhou, P.J.; Liu, C.B.; Dong, H.J.; Li, C.X.; Song, N.; Li, C.M. Nitrogen doped carbon ribbons modified g- $\mathrm{C}_{3} \mathrm{~N}_{4}$ for markedly enhanced photocatalytic $\mathrm{H}_{2}$-production in visible to near-infrared region. Chem. Eng. J. 2020, 382, 9. [CrossRef]

57. Hao, Q.G.; Song, Y.H.; Ji, H.Y.; Mo, Z.; She, X.J.; Deng, J.J.; Muhmood, T.; Wu, X.Y.; Yuan, S.Q.; Xu, H.; et al. Surface $\mathrm{N}$ modified 2D g- $\mathrm{C}_{3} \mathrm{~N}_{4}$ nanosheets derived from DMF for photocatalytic $\mathrm{H} 2$ evolution. Appl. Surf. Sci. 2018, 459, 845-852. [CrossRef]

58. Huang, Q.; Yu, J.G.; Cao, S.W.; Cui, C.; Cheng, B. Efficient photocatalytic reduction of $\mathrm{CO}_{2}$ by amine-functionalized g- $\mathrm{C}_{3} \mathrm{~N}_{4}$. Appl. Surf. Sci. 2015, 358, 350-355. [CrossRef]

59. Yan, J.; Zhou, C.J.; Li, P.R.; Chen, B.H.; Zhang, S.S.; Dong, X.P.; Xi, F.N.; Liu, J.Y. Nitrogen-rich graphitic carbon nitride: Controllable nanosheet-like morphology, enhanced visible light absorption and superior photocatalytic performance. Colloids Surf. A Physicochem. Eng. Asp. 2016, 508, 257-264. [CrossRef]

60. Gao, B.R.; Wang, J.; Dou, M.M.; Huang, X.; Yu, X.X. Novel nitrogen-rich g-C3N4 with adjustable energy band by introducing triazole ring for cefotaxime removal. Sep. Purif. Technol. 2020, 241, 9. [CrossRef]

61. Wu, X.H.; Gao, D.D.; Wang, P.; Yu, H.G.; Yu, J.G. NH4Cl-induced low-temperature formation of nitrogen-rich g- $\mathrm{C}_{3} \mathrm{~N}_{4}$ nanosheets with improved photocatalytic hydrogen evolution. Carbon 2019, 153, 757-766. [CrossRef]

62. Mo, Z.; Zhu, X.W.; Jiang, Z.F.; Song, Y.H.; Liu, D.B.; Li, H.P.; Yang, X.F.; She, Y.B.; Lei, Y.C.; Yuan, S.Q.; et al. Porous nitrogen-rich $\mathrm{g}-\mathrm{C}_{3} \mathrm{~N}_{4}$ nanotubes for efficient photocatalytic $\mathrm{CO}_{2}$ reduction. Appl. Catal. B Environ. 2019, 256, 7. [CrossRef]

63. Zhou, Y.J.; Zhang, L.X.; Huang, W.M.; Kong, Q.L.; Fan, X.Q.; Wang, M.; Shi, J.L. N-doped graphitic carbon-incorporated $\mathrm{g}-\mathrm{C}_{3} \mathrm{~N}_{4}$ for remarkably enhanced photocatalytic $\mathrm{H}_{2}$ evolution under visible light. Carbon 2016, 99, 111-117. [CrossRef]

64. Tian, N.; Zhang, Y.H.; Li, X.W.; Xiao, K.; Du, X.; Dong, F.; Waterhouse, G.I.N.; Zhang, T.R.; Huang, H.W. Precursor-reforming protocol to $3 \mathrm{D}$ mesoporous $\mathrm{g}-\mathrm{C}_{3} \mathrm{~N}_{4}$ established by ultrathin self-doped nanosheets for superior hydrogen evolution. Nano Energy 2017, 38, 72-81. [CrossRef]

65. Wu, M.; Gong, Y.S.; Nie, T.; Zhang, J.; Wang, R.; Wang, H.W.; He, B.B. Template-free synthesis of nanocage-like g-C3N4 with high surface area and nitrogen defects for enhanced photocatalytic $\mathrm{H}_{2}$ activity. J. Mater. Chem. A 2019, 7, 5324-5332. [CrossRef] 
66. Wang, F.L.; Chen, P.; Feng, Y.P.; Xie, Z.J.; Liu, Y.; Su, Y.H.; Zhang, Q.X.; Wang, Y.F.; Yao, K.; Lv, W.Y.; et al. Facile synthesis of N-doped carbon dots/g- $\mathrm{C}_{3} \mathrm{~N}_{4}$ photocatalyst with enhanced visible-light photocatalytic activity for the degradation of indomethacin. Appl. Catal. B Environ. 2017, 207, 103-113. [CrossRef]

67. Asadzadeh-Khaneghah, S.; Habibi-Yangjeh, A.; Nakata, K. Decoration of carbon dots over hydrogen peroxide treated graphitic carbon nitride: Exceptional photocatalytic performance in removal of different contaminants under visible light. J. Photochem. Photobiol. A Chem. 2019, 374, 161-172. [CrossRef]

68. Deng, P.H.; Li, H.Y.; Wang, Z.D.; Hou, Y. Enhanced photocatalytic hydrogen evolution by carbon-doped carbon nitride synthesized via the assistance of cellulose. Appl. Surf. Sci. 2020, 504. [CrossRef]

69. Duan, Y.; Deng, L.; Shi, Z.; Liu, X.; Zeng, H.X.; Zhang, H.J.; Crittenden, J. Efficient sulfadiazine degradation via in-situ epitaxial grow of Graphitic Carbon Nitride $\left(\mathrm{g}-\mathrm{C}_{3} \mathrm{~N}_{4}\right)$ on carbon dots heterostructures under visible light irradiation: Synthesis, mechanisms and toxicity evaluation. J. Colloid Interface Sci. 2020, 561, 696-707. [CrossRef]

70. Jeong, T.; Piao, H.; Park, S.; Yang, J.H.; Choi, G.; Wu, Q.; Kang, H.; Woo, H.J.; Jung, S.J.; Kim, H.; et al. Atomic and electronic structures of graphene-decorated graphitic carbon nitride $\left(\mathrm{g}-\mathrm{C}_{3} \mathrm{~N}_{4}\right)$ as a metal-free photocatalyst under visible-light. Appl. Catal. B Environ. 2019, 256, 7. [CrossRef]

71. Cao, J.S.; Fan, H.Q.; Wang, C.; Ma, J.W.; Dong, G.Z.; Zhang, M.C. Facile synthesis of carbon self-doped $\mathrm{g}_{-} \mathrm{C}_{3} \mathrm{~N}_{4}$ for enhanced photocatalytic hydrogen evolution. Ceram. Int. 2020, 46, 7888-7895. [CrossRef]

72. Chatzoudis, A.; Giannopoulos, V.; Hollmann, F.; Smonou, I. Surface-Doped Graphitic Carbon Nitride Catalyzed Photooxidation of Olefins and Dienes: Chemical Evidence for Electron Transfer and Singlet Oxygen Mechanisms. Catalysts 2019, 9, 639. [CrossRef]

73. Ge, F.Y.; Xu, Y.G.; Zhou, Y.H.; Tian, D.; Huang, S.Q.; Xie, M.; Xu, H.; Li, H.M. Surface amorphous carbon doping of carbon nitride for efficient acceleration of electron transfer to boost photocatalytic activities. Appl. Surf. Sci. 2020, 507. [CrossRef]

74. Li, Z.H.; Huang, D.L.; Zhou, C.Y.; Xue, W.J.; Lei, L.; Deng, R.; Yang, Y.; Chen, S.; Wang, W.J.; Wang, Z.W. Metal-free carbon nitride with boosting photo-redox ability realized by the controlled carbon dopants. Chem. Eng. J. 2020, 382. [CrossRef]

75. Liu, H.P.; Liang, J.; Fu, S.; Li, L.; Cui, J.H.; Gao, P.H.; Zhao, F.Y.; Zhou, J.G. N doped carbon quantum dots modified defect-rich $\mathrm{g}-{ }_{-}{ }_{3 N} 4$ for enhanced photocatalytic combined pollutions degradation and hydrogen evolution. Colloids Surf. A Physicochem. Eng. Asp. 2020, 591, 13. [CrossRef]

76. Long, D.; Chen, W.L.; Rao, X.; Zheng, S.H.; Zhang, Y.P. Synergetic effect of C-60/g- $\mathrm{C}_{3} \mathrm{~N}_{4}$ nanowire composites for enhanced photocatalytic $\mathrm{H}_{2}$ evolution under visible light irradiation. ChemCatChem 2020, 12, 2022-2031. [CrossRef]

77. Meng, L.R.; Yin, W.H.; Wang, S.S.; Wu, X.G.; Hou, J.H.; Yin, W.Q.; Feng, K.; Ok, Y.S.; Wang, X.Z. Photocatalytic behavior of biochar-modified carbon nitride with enriched visible-light reactivity. Chemosphere 2020, 239. [CrossRef]

78. Wang, X.F.; Cheng, J.J.; Yu, H.G.; Yu, J.G. A facile hydrothermal synthesis of carbon dots modified g- ${ }_{3} \mathrm{~N}_{4}$ for enhanced photocatalytic $\mathrm{H}_{2}$-evolution performance. Dalton Trans. 2017, 46, 6417-6424. [CrossRef] [PubMed]

79. Wang, Y.M.; Cai, H.Y.; Qian, F.F.; Li, Y.M.; Yu, J.Q.; Yang, X.L.; Bao, M.T.; Li, X.M. Facile one-step synthesis of onion-like carbon modified ultrathin $g-\mathrm{C}_{3} \mathrm{~N}_{4} 2 \mathrm{D}$ nanosheets with enhanced visible-light photocatalytic performance. J. Colloid Interface Sci. 2019, 533, 47-58. [CrossRef] [PubMed]

80. Huang, Y.Y.; Li, D.; Fang, Z.Y.; Chen, R.J.; Luo, B.F.; Shi, W.D. Controlling carbon self-doping site of g- ${ }_{3} \mathrm{~N}_{4}$ for highly enhanced visible-light-driven hydrogen evolution. Appl. Catal. B Environ. 2019, 254, 128-134. [CrossRef]

81. Li, X.L.; Bai, J.F.; Li, J.Q.; Li, C.; Zhong, X.Y.; Deng, S.P. The effect of n-pi* electronic transitions on the $\mathrm{N}-2$ photofixation ability of carbon self-doped honeycomb-like g- $\mathrm{C}_{3} \mathrm{~N}_{4}$ prepared via microwave treatment. RSC Adv. 2020, 10, 7019-7025. [CrossRef]

82. Ran, M.X.; Li, J.R.; Cui, W.; Li, Y.H.; Li, P.D.; Dong, F. Efficient and stable photocatalytic NO removal on C self-doped $g-\mathrm{C}_{3} \mathrm{~N}_{4}$ : Electronic structure and reaction mechanism. Catal. Sci. Technol. 2018, 8, 3387-3394. [CrossRef]

83. Xu, Q.L.; Jiang, C.J.; Cheng, B.; Yu, J.G. Enhanced visible-light photocatalytic $\mathrm{H}_{2}$-generation activity of carbon/g- $\mathrm{C}_{3} \mathrm{~N}_{4}$ nanocomposites prepared by two-step thermal treatment. Dalton Trans. 2017, 46, 10611-10619. [CrossRef] [PubMed] 
84. Xu, J.; Huang, J.; Wang, Z.P.; Zhu, Y.F. Enhanced visible-light photocatalytic degradation and disinfection performance of oxidized nanoporous $\mathrm{g}-\mathrm{C}_{3} \mathrm{~N}_{4}$ via decoration with graphene oxide quantum dots. Chin. J. Catal. 2020, 41, 474-484. [CrossRef]

85. Bao, N.; Hu, X.D.; Zhang, Q.Z.; Miao, X.H.; Jie, X.Y.; Zhou, S. Synthesis of porous carbon-doped g-C $\mathrm{C}_{3} \mathrm{~N}_{4}$ nanosheets with enhanced visible-light photocatalytic activity. Appl. Surf. Sci. 2017, 403, 682-690. [CrossRef]

86. Chen, Z.; Fan, T.T.; Yu, X.; Wu, Q.L.; Zhu, Q.H.; Zhang, L.Z.; Li, J.H.; Fang, W.P.; Yi, X.D. Gradual carbon doping of graphitic carbon nitride towards metal-free visible light photocatalytic hydrogen evolution. J. Mater. Chem. A 2018, 6, 15310-15319. [CrossRef]

87. Luo, L.; Ma, J.N.; Zhu, H.X.; Tang, J.W. Embedded carbon in a carbon nitride hollow sphere for enhanced charge separation and photocatalytic water splitting. Nanoscale 2020, 12, 7339-7346. [CrossRef]

88. Li, J.X.; Ma, W.Q.; Chen, J.J.; An, N.; Zhao, Y.; Wang, D.J.; Mao, Z.Y. Carbon vacancies improved photocatalytic hydrogen generation of $\mathrm{g}-\mathrm{C}_{3} \mathrm{~N}_{4}$ photocatalyst via magnesium vapor etching. Int. J. Hydrogen Energy 2020, 45, 13939-13946. [CrossRef]

89. Ma, L.; Hu, S.Z.; Li, P.; Wang, Q.; Ma, H.F.; Li, W. In situ synthesis of sulfur doped carbon nitride with enhanced photocatalytic performance using DBD plasma treatment under $\mathrm{H}_{2} \mathrm{~S}$ atmosphere. J. Phys. Chem. Solids 2018, 118, 166-171. [CrossRef]

90. Lv, H.Q.; Huang, Y.; Koodali, R.T.; Liu, G.M.; Zeng, Y.B.; Meng, Q.G.; Yuan, M.Z. Synthesis of Sulfur-Doped 2D Graphitic Carbon Nitride Nanosheets for Efficient Photocatalytic Degradation of Phenol and Hydrogen Evolution. ACS Appl. Mater. Interfaces 2020, 12, 12656-12667. [CrossRef]

91. Wang, W.J.; Zeng, Z.T.; Zeng, G.M.; Zhang, C.; Xiao, R.; Zhou, C.Y.; Xiong, W.P.; Yang, Y.; Lei, L.; Liu, Y.; et al. Sulfur doped carbon quantum dots loaded hollow tubular $\mathrm{g}-\mathrm{C}_{3} \mathrm{~N}_{4}$ as novel photocatalyst for destruction of Escherichia coli and tetracycline degradation under visible light. Chem. Eng. J. 2019, 378, 11. [CrossRef]

92. Joseph, S.; Abraham, S.; Priyanka, R.N.; Abraham, T.; Suresh, A.; Mathew, B. In situ S-doped ultrathin $\mathrm{gC}(3) \mathrm{N}(4)$ nanosheets coupled with mixed-dimensional (3D/1D) nanostructures of silver vanadates for enhanced photocatalytic degradation of organic pollutants. New J. Chem. 2019, 43, 10618-10630. [CrossRef]

93. Sakthivel, A.; Chandrasekaran, A.; Jayakumar, S.; Manickam, P.; Alwarappan, S. Sulphur Doped Graphitic Carbon Nitride as an Efficient Electrochemical Platform for the Detection of Acetaminophen. J. Electrochem. Soc. 2019, 166, B1461-B1469. [CrossRef]

94. Fang, Y.X.; Li, X.C.; Wang, Y.; Giordano, C.; Wang, X.C. Gradient sulfur doping along polymeric carbon nitride films as visible light photoanodes for the enhanced water oxidation. Appl. Catal. B Environ. 2020, 268, 6. [CrossRef]

95. Fan, Q.J.; Liu, J.J.; Yu, Y.C.; Zuo, S.L.; Li, B.S. A simple fabrication for sulfur doped graphitic carbon nitride porous rods with excellent photocatalytic activity degrading RhB dye. Appl. Surf. Sci. 2017, 391, 360-368. [CrossRef]

96. Lin, Y.R.; Dizon, G.V.C.; Yamada, K.; Liu, C.Y.; Venault, A.; Lin, H.Y.; Yoshida, M.; Hu, C.C. Sulfur-doped g- $\mathrm{C}_{3} \mathrm{~N}_{4}$ nanosheets for photocatalysis: Z-scheme water splitting and decreased biofouling. J. Colloid Interface Sci. 2020, 567, 202-212. [CrossRef]

97. Lu, C.H.; Zhang, P.; Jiang, S.J.; Wu, X.; Song, S.Q.; Zhu, M.S.; Lou, Z.Z.; Li, Z.; Liu, F.; Liu, Y.H.; et al. Photocatalytic reduction elimination of $\mathrm{UO} 22+$ pollutant under visible light with metal-free sulfur doped g- $\mathrm{C}_{3} \mathrm{~N}_{4}$ photocatalyst. Appl. Catal. B Environ. 2017, 200, 378-385. [CrossRef]

98. Wang, K.; Li, Q.; Liu, B.S.; Cheng, B.; Ho, W.K.; Yu, J.G. Sulfur-doped g- $\mathrm{C}_{3} \mathrm{~N}_{4}$ with enhanced photocatalytic $\mathrm{CO}_{2}$-reduction performance. Appl. Catal. B Environ. 2015, 176, 44-52. [CrossRef]

99. Praus, P.; Smykalova, A.; Foniok, K.; Velisek, P.; Cvejn, D.; Zadny, J.; Storch, J. Post-Synthetic Derivatization of Graphitic Carbon Nitride with Methanesulfonyl Chloride: Synthesis, Characterization and Photocatalysis. Nanomaterials 2020, 10, 193. [CrossRef]

100. Qin, H.F.; Lv, W.H.; Bai, J.R.; Zhou, Y.; Wen, Y.P.; He, Q.T.; Tang, J.H.; Wang, L.B.; Zhou, Q.F. Sulfur-doped porous graphitic carbon nitride heterojunction hybrids for enhanced photocatalytic $\mathrm{H}_{2}$ evolution. J. Mater. Sci. 2019, 54, 4811-4820. [CrossRef]

101. Ke, L.; Li, P.F.; Wu, X.; Jiang, S.J.; Luo, M.B.; Liu, Y.H.; Le, Z.G.; Sun, C.Z.; Song, S.Q. Graphene-like sulfur-doped $\mathrm{g}-\mathrm{C}_{3} \mathrm{~N}_{4}$ for photocatalytic reduction elimination of $\mathrm{UO} 22+$ under visible Light. Appl. Catal. B Environ. 2017, 205, 319-326. [CrossRef] 
102. Raziq, F.; Humayun, M.; Ali, A.; Wang, T.T.; Khan, A.; Fu, Q.Y.; Luo, W.; Zeng, H.P.; Zheng, Z.P.; Khan, B.; et al. Synthesis of S-Doped porous $\mathrm{g}_{-} \mathrm{C}_{3} \mathrm{~N}_{4}$ by using ionic liquids and subsequently coupled with $\mathrm{Au}-\mathrm{TiO}_{2}$ for exceptional cocatalyst-free visible-light catalytic activities. Appl. Catal. B Environ. 2018, 237, 1082-1090. [CrossRef]

103. Li, Y.F.; Wang, S.; Chang, W.; Zhang, L.H.; Wu, Z.S.; Song, S.Y.; Xing, Y. Preparation and enhanced photocatalytic performance of sulfur doped terminal-methylated $\mathrm{g}-\mathrm{C}_{3} \mathrm{~N}_{4}$ nanosheets with extended visible-light response. J. Mater. Chem. A 2019, 7, 20640-20648. [CrossRef]

104. Cui, Y.J.; Li, M.; Wang, H.; Yang, C.F.; Meng, S.G.; Chen, F.Y. In-situ synthesis of sulfur doped carbon nitride microsphere for outstanding visible light photocatalytic Cr (VI) reduction. Sep. Purif. Technol. 2018, 199, 251-259. [CrossRef]

105. Mohammad, A.; Khan, M.E.; Cho, M.H. Sulfur-doped-graphitic-carbon nitride $\left(\mathrm{S}-\mathrm{g}-\mathrm{C}_{3} \mathrm{~N}_{4}\right)$ for low cost electrochemical sensing of hydrazine. J. Alloy. Compd. 2020, 816, 10. [CrossRef]

106. Guo, H.; Shu, Z.; Chen, D.H.; Tan, Y.G.; Zhou, J.; Meng, F.Y.; Li, T.T. One-step synthesis of S-doped g- $\mathrm{C}_{3} \mathrm{~N}_{4}$ nanosheets for improved visible-light photocatalytic hydrogen evolution. Chem. Phys. 2020, 533, 7. [CrossRef]

107. Xie, L.L.; Dai, Y.R.; Zhou, Y.J.; Chang, X.; Yin, L.F. Sulfur (VI) modified graphite carbon nitride nanosheets with chrysanthemum-like structure and enhanced photocatalytic activity. Chem. Phys. Lett. 2018, 693, 1-7. [CrossRef]

108. Cao, J.J.; Wang, H.; Zhao, Y.J.; Liu, Y.; Wu, Q.Y.; Huang, H.; Shao, M.W.; Kang, Z.H. Phosphorus-doped porous carbon nitride for efficient sole production of hydrogen peroxide via photocatalytic water splitting with a two-channel pathway. J. Mater. Chem. A 2020, 8, 3701-3707. [CrossRef]

109. Zhu, Y.K.; Li, J.Z.; Cao, J.M.; Lv, C.X.; Huang, G.Q.; Zhang, G.L.; Xu, Y.; Zhang, S.C.; Meng, P.P.; Zhan, T.R.; et al. Phosphorus-doped polymeric carbon nitride nanosheets for enhanced photocatalytic hydrogen production. APL Mater. 2020, 8, 7. [CrossRef]

110. Chai, B.; Yan, J.T.; Wang, C.L.; Ren, Z.D.; Zhu, Y.C. Enhanced visible light photocatalytic degradation of Rhodamine B over phosphorus doped graphitic carbon nitride. Appl. Surf. Sci. 2017, 391, 376-383. [CrossRef]

111. Chegeni, M.; Dehghan, N. Preparation of Phosphorus Doped Graphitic Carbon Nitride Using a Simple Method and Its Application for Removing Methylene Blue. Phys. Chem. Res. 2020, 8, 31-44. [CrossRef]

112. Huang, J.X.; Li, D.G.; Li, R.B.; Zhang, Q.X.; Chen, T.S.; Liu, H.J.; Liu, Y.; Lv, W.Y.; Liu, G.G. An efficient metal-free phosphorus and oxygen co-doped $g-\mathrm{C}_{3} \mathrm{~N}_{4}$ photocatalyst with enhanced visible light photocatalytic activity for the degradation of fluoroquinolone antibiotics. Chem. Eng. J. 2019, 374, 242-253. [CrossRef]

113. Huang, J.X.; Li, D.G.; Liu, Y.; Li, R.B.; Chen, P.; Liu, H.J.; Lv, W.Y.; Liu, G.G.; Feng, Y.P. Ultrathin $\mathrm{Ag}_{2} \mathrm{WO}_{4}$-coated P-doped g- $\mathrm{C}_{3} \mathrm{~N}_{4}$ nanosheets with remarkable photocatalytic performance for indomethacin degradation. J. Hazard. Mater. 2020, 392, 13. [CrossRef] [PubMed]

114. Kesavan, T.; Partheeban, T.; Vivekanantha, M.; Prabu, N.; Kundu, M.; Premkumar, S.; Umapathy, S.; Vinu, A.; Sasidharan, M. Design of P-Doped Mesoporous Carbon Nitrides as High-Performance Anode Materials for Li-Ion Battery. ACS Appl. Mater. Interfaces 2020, 12, 24007-24018. [CrossRef]

115. Li, J.J.; Tian, C.; Zhao, H.; Mei, J.; Zhang, J.; Yang, S.J. Controllable fabrication of a red phosphorus modified $\mathrm{g}-\mathrm{C}_{3} \mathrm{~N}_{4}$ photocatalyst with strong interfacial binding for the efficient removal of organic pollutants. J. Alloy. Compd. 2019, 810. [CrossRef]

116. Jolliffe, I.T. Principal Component Analysis. In Principal Component Analysis; Springer: New York, NY, USA, 1986; pp. 115-128. [CrossRef]

117. Ran, J.R.; Guo, W.W.; Wang, H.L.; Zhu, B.C.; Yu, J.G.; Qiao, S.Z. Metal-Free 2D/2D Phosphorene/g-C ${ }_{3} \mathrm{~N}_{4}$ Van der Waals Heterojunction for Highly Enhanced Visible-Light Photocatalytic $\mathrm{H}_{2}$ Production. Adv. Mater. 2018, 30, 6. [CrossRef]

118. Su, C.Y.; Zhou, Y.Z.; Zhang, L.L.; Yu, X.H.; Gao, S.; Sun, X.J.; Cheng, C.; Liu, Q.Q.; Yang, J. Enhanced $n$ $\rightarrow$ pi $^{*}$ electron transition of porous P-doped $\mathrm{g}-\mathrm{C}_{3} \mathrm{~N}_{4}$ nanosheets for improved photocatalytic $\mathrm{H}_{2}$ evolution performance. Ceram. Int. 2020, 46, 8444-8451. [CrossRef]

119. Sun, Y.J.; He, J.Y.; Zhang, D.; Wang, X.J.; Zhao, J.; Liu, R.H.; Li, F.T. Simultaneous construction of dual-site phosphorus modified $\mathrm{g}_{-} \mathrm{C}_{3} \mathrm{~N}_{4}$ and its synergistic mechanism for enhanced visible-light photocatalytic hydrogen evolution. Appl. Surf. Sci. 2020, 517, 8. [CrossRef] 
120. Wang, P.Y.; Guo, C.S.; Hou, S.; Zhao, X.; Wu, L.L.; Pei, Y.Y.; Zhang, Y.; Gao, J.F.; Xu, J. Template-free synthesis of bubble-like phosphorus-doped carbon nitride with enhanced visible-light photocatalytic activity. J. Alloy. Compd. 2018, 769, 503-511. [CrossRef]

121. Zhao, Z.L.; Xie, C.; Cui, H.D.; Wang, Q.Y.; Shu, Z.; Zhou, J.; Li, T.T. Scalable one-pot synthesis of phosphorus-doped $\mathrm{g}_{3} \mathrm{C}_{3} \mathrm{~N}_{4}$ nanosheets for enhanced visible-light photocatalytic hydrogen evolution. Diam. Relat. Mat. 2020, 104, 8. [CrossRef]

122. Deng, Y.C.; Tang, L.; Zeng, G.M.; Zhu, Z.J.; Yan, M.; Zhou, Y.Y.; Wang, J.J.; Liu, Y.N. Insight into highly efficient simultaneous photocatalytic removal of $\mathrm{Cr}(\mathrm{VI})$ and 2,4-diclorophenol under visible light irradiation by phosphorus doped porous ultrathin $\mathrm{g}-\mathrm{C}_{3} \mathrm{~N}_{4}$ nanosheets from aqueous media: Performance and reaction mechanism. Appl. Catal. B Environ. 2017, 203, 343-354. [CrossRef]

123. Zhu, Y.P.; Ren, T.Z.; Yuan, Z.Y. Mesoporous Phosphorus-Doped g- $\mathrm{C}_{3} \mathrm{~N}_{4}$ Nanostructured Flowers with Superior Photocatalytic Hydrogen Evolution Performance. ACS Appl. Mater. Interfaces 2015, 7, 16850-16856. [CrossRef] [PubMed]

124. He, F.; Wang, Z.X.; Li, Y.X.; Peng, S.Q.; Liu, B. The nonmetal modulation of composition and morphology of g- $\mathrm{C}_{3} \mathrm{~N}_{4}$-based photocatalysts. Appl. Catal. B Environ. 2020, 269, 21. [CrossRef]

125. Guo, S.E.; Tang, Y.Q.; Xie, Y.; Tian, C.G.; Feng, Q.M.; Zhou, W.; Jiang, B.J. P-doped tubular g-C ${ }_{3} \mathrm{~N}_{4}$ with surface carbon defects: Universal synthesis and enhanced visible-light photocatalytic hydrogen production. Appl. Catal. B Environ. 2017, 218, 664-671. [CrossRef]

126. Zhou, Y.J.; Zhang, L.X.; Liu, J.J.; Fan, X.Q.; Wang, B.Z.; Wang, M.; Ren, W.C.; Wang, J.; Li, M.L.; Shi, J.L. Brand new P-doped g- $\mathrm{C}_{3} \mathrm{~N}_{4}$ : Enhanced photocatalytic activity for $\mathrm{H}_{2}$ evolution and Rhodamine B degradation under visible light. J. Mater. Chem. A 2015, 3, 3862-3867. [CrossRef]

127. Li, X.H.; Zhang, J.; Zhou, F.; Zhang, H.L.; Bai, J.; Wang, Y.J.; Wang, H.Y. Preparation of N-vacancy-doped g- $\mathrm{C}_{3} \mathrm{~N}_{4}$ with outstanding photocatalytic $\mathrm{H}_{2} \mathrm{O}_{2}$ production ability by dielectric barrier discharge plasma treatment. Chin. J. Catal. 2018, 39, 1090-1098. [CrossRef]

128. Li, H.L.; Jin, C.; Wang, Z.Y.; Liu, Y.Y.; Wang, P.; Zheng, Z.K.; Whangbo, M.H.; Kou, L.Z.; Li, Y.J.; Dai, Y.; et al. Effect of the intra- and inter-triazine $\mathrm{N}$-vacancies on the photocatalytic hydrogen evolution of graphitic carbon nitride. Chem. Eng. J. 2019, 369, 263-271. [CrossRef]

129. Peng, G.M.; Wu, J.W.; Wang, M.Z.; Niklas, J.; Zhou, H.; Liu, C. Nitrogen-Defective Polymeric Carbon Nitride Nanolayer Enabled Efficient Electrocatalytic Nitrogen Reduction with High Faradaic Efficiency. Nano Lett. 2020, 20, 2879-2885. [CrossRef]

130. Li, X.X.; Tan, T.N.; Zhang, J.; Zhang, N.; He, J.W.; Han, W.M.; Wang, Y.D.; Pan, M. Nitrogen Deficient Graphitic Carbon Nitride as Anodes for Lithium-ion Batteries. J. Wuhan Univ. Technol. Mat. Sci. Edit. 2020, 35, 263-271. [CrossRef]

131. Xie, Y.; Li, Y.X.; Huang, Z.H.; Zhang, J.Y.; Jia, X.F.; Wang, X.S.; Ye, J.H. Two types of cooperative nitrogen vacancies in polymeric carbon nitride for efficient solar-driven $\mathrm{H}_{2} \mathrm{O}_{2}$ evolution. Appl. Catal. B Environ. 2020, 265, 7. [CrossRef]

132. Wang, J.; Gao, B.; Dou, M.M.; Huang, X.; Ma, Z.K. A porous g- $\mathrm{C}_{3} \mathrm{~N}_{4}$ nanosheets containing nitrogen defects for enhanced photocatalytic removal meropenem: Mechanism, degradation pathway and DFT calculation. Environ. Res. 2020, 184, 10. [CrossRef]

133. Wang, Y.X.; Rao, L.; Wang, P.F.; Guo, Y.; Shi, Z.Y.; Guo, X.; Zhang, L.X. Synthesis of nitrogen vacancies g- $\mathrm{C}_{3} \mathrm{~N}_{4}$ with increased crystallinity under the controlling of oxalyl dihydrazide: Visible-light-driven photocatalytic activity. Appl. Surf. Sci. 2020, 505, 10. [CrossRef]

134. Yu, W.W.; Shan, X.; Zhao, Z.K. Unique nitrogen-deficient carbon nitride homojunction prepared by a facile inserting-removing strategy as an efficient photocatalyst for visible light-driven hydrogen evolution. Appl. Catal. B Environ. 2020, 269, 9. [CrossRef]

135. Li, X.X.; Zhang, K.L.; Zhou, M.; Yang, K.; Yang, S.; Ma, X.H.; Yu, C.L.; Xie, Y.; Huang, W.Y.; Fan, Q.Z. A Novel Approach to Synthesize Nitrogen-Deficient $g-\mathrm{C}_{3} \mathrm{~N}_{4}$ for the Enhanced Photocatalytic Contaminant Degradation and Electrocatalytic Hydrogen Evolution. Nano 2020, 15, 13. [CrossRef]

136. Yang, Z.X.; Chu, D.L.; Jia, G.R.; Yao, M.G.; Liu, B.B. Significantly narrowed bandgap and enhanced charge separation in porous, nitrogen-vacancy red $\mathrm{g}-\mathrm{C}_{3} \mathrm{~N}_{4}$ for visible light photocatalytic $\mathrm{H}_{2}$ production. Appl. Surf. Sci. 2020, 504, 8. [CrossRef] 
137. Huang, J.J.; Du, J.M.; Du, H.W.; Xu, G.S.; Yuan, Y.P. Control of Nitrogen Vacancy in g- $\mathrm{C}_{3} \mathrm{~N}_{4}$ by Heat Treatment in an Ammonia Atmosphere for Enhanced Photocatalytic Hydrogen Generation. Acta Phys. Chim. Sin. 2020, 36, 8. [CrossRef]

138. Li, W.S.; Guo, Z.; Jiang, L.T.; Zhong, L.; Li, G.N.; Zhang, J.J.; Fan, K.; Gonzalez-Cortes, S.; Jin, K.J.; Xu, C.J.; et al. Facile in situ reductive synthesis of both nitrogen deficient and protonated $g-\mathrm{C}_{3} \mathrm{~N}_{4}$ nanosheets for the synergistic enhancement of visible-light $\mathrm{H}_{2}$ evolution. Chem. Sci. 2020, 11, 2716-2728. [CrossRef]

139. Zhang, Y.; Di, J.; Ding, P.H.; Zhao, J.Z.; Gu, K.Z.; Chen, X.L.; Yan, C.; Yin, S.; Xia, J.X.; Li, H.M. Ultrathin g- $\mathrm{C}_{3} \mathrm{~N}_{4}$ with enriched surface carbon vacancies enables highly efficient photocatalytic nitrogen fixation. J. Colloid Interface Sci. 2019, 553, 530-539. [CrossRef]

140. Li, Y.H.; Gu, M.L.; Shi, T.; Cui, W.; Zhang, X.M.; Dong, F.; Cheng, J.S.; Fan, J.J.; Lv, K.L. Carbon vacancy in $\mathrm{C}_{3} \mathrm{~N}_{4}$ nanotube: Electronic structure, photocatalysis mechanism and highly enhanced activity. Appl. Catal. B Environ. 2020, 262, 11. [CrossRef]

141. Li, S.N.; Dong, G.H.; Hailili, R.; Yang, L.P.; Li, Y.X.; Wang, F.; Zeng, Y.B.; Wang, C.Y. Effective photocatalytic $\mathrm{H}_{2} \mathrm{O}_{2}$ production under visible light irradiation at $\mathrm{g}-\mathrm{C}_{3} \mathrm{~N}_{4}$ modulated by carbon vacancies. Appl. Catal. B Environ. 2016, 190, 26-35. [CrossRef]

142. Barrio, J.; Volokh, M.; Shalom, M. Polymeric carbon nitrides and related metal-free materials for energy and environmental applications. J. Mater. Chem. A 2020, 8, 11075-11116. [CrossRef]

143. Liu, X.L.; Ma, R.; Zhuang, L.; Hu, B.W.; Chen, J.R.; Liu, X.Y.; Wang, X.K. Recent developments of doped g- $\mathrm{C}_{3} \mathrm{~N}_{4}$ photocatalysts for the degradation of organic pollutants. Crit. Rev. Environ. Sci. Technol. 2020, 40. [CrossRef]

144. Mun, S.J.; Park, S.J. Graphitic Carbon Nitride Materials for Photocatalytic Hydrogen Production via Water Splitting: A Short Review. Catalysts 2019, 9, 805. [CrossRef]

145. Talapaneni, S.N.; Singh, G.; Kim, I.Y.; AlBahily, K.; Al-Muhtaseb, A.H.; Karakoti, A.S.; Tavakkoli, E.; Vinu, A. Nanostructured Carbon Nitrides for $\mathrm{CO}_{2}$ Capture and Conversion. Adv. Mater. 2020, 32, 21. [CrossRef]

146. Wang, Y.Q.; Shen, S.H. Progress and Prospects of Non-Metal Doped Graphitic Carbon Nitride for Improved Photocatalytic Performances. Acta Phys. Chim. Sin. 2020, 36, 14. [CrossRef]

147. Zhu, A.H.; Qiu, B.C.; Du, M.M.; Ji, J.H.; Nasir, M.; Xing, M.Y.; Zhang, J.L. Dopant-Induced Edge and Basal Plane Catalytic Sites on Ultrathin $\mathrm{C}_{3} \mathrm{~N}_{4}$ Nanosheets for Photocatalytic Water Reduction. Acs Sustain. Chem. Eng. 2020, 8, 7497-7502. [CrossRef]

148. Wanninayake, N.; Ai, Q.; Zhou, R.; Hoque, M.A.; Herrell, S.; Guzman, M.I.; Risko, C.; Kim, D.Y. Understanding the effect of host structure of nitrogen doped ultrananocrystalline diamond electrode on electrochemical carbon dioxide reduction. Carbon 2020, 157, 408-419. [CrossRef]

149. Zhao, H.L.; Liu, L.J.; Andino, J.M.; Li, Y. Bicrystalline $\mathrm{TiO}_{2}$ with controllable anatase-brookite phase content for enhanced $\mathrm{CO}_{2}$ photoreduction to fuels. J. Mater. Chem. A 2013, 1, 8209-8216. [CrossRef]

150. Hoque, M.A.; Guzman, M.I. Photocatalytic Activity: Experimental Features to Report in Heterogeneous Photocatalysis. Materials 2018, 11, 1990. [CrossRef] 